\author{
UNIVERSIDADE DE SÃO PAULO \\ FACULDADE DE FILOSOFIA, LETRAS E CIÊNCIAS HUMANAS \\ DEPARTAMENTO DE LETRAS MODERNAS \\ PROGRAMA DE PÓS-GRADUAÇÃO EM \\ ESTUDOS LINGÜÍSTICOS E LITERÁRIOS EM INGLÊS
}

\title{
TRADUÇÃO DO DIALETO LITERÁRIO DE BURMA JONES, DA OBRA A CONFEDERACY OF DUNCES, DE JOHN KENNEDY TOOLE
}

\begin{abstract}
Dissertação apresentada ao Programa de Pós-Graduação em Estudos Lingüísticos e Literários em Inglês, do Departamento de Letras Modernas da Faculdade de Filosofia, Letras e Ciências Sociais da Universidade de São Paulo, para obtenção do título de Mestre em Letras.
\end{abstract}

Orientadora: Prof ${ }^{\mathrm{a}}$. Dr ${ }^{\mathrm{a}}$. Lenita Maria Rimoli Esteves

São Paulo 
UNIVERSIDADE DE SÃO PAULO

FACULDADE DE FILOSOFIA, LETRAS E CIÊNCIAS HUMANAS

DEPARTAMENTO DE LETRAS MODERNAS

PROGRAMA DE PÓS-GRADUAÇÃO EM

ESTUDOS LINGÜÍSTICOS E LITERÁRIOS EM INGLÊS

\section{TRADUÇÃO DO DIALETO LITERÁRIO DE BURMA JONES, DA OBRA A CONFEDERACY OF DUNCES, DE JOHN KENNEDY TOOLE}

Kátia Regina Vighy Hanna

São Paulo 
À minha filha, Emília, pelo tempo de convivência que este trabalho nos privou.

À cidade de New Orleans, injustamente destruída pelo furacão Katrina e pelo governo George W. Bush. 


\section{AGRADECIMENTOS}

Agradeço de coração à Profa. Dra. Lenita Maria Rimoli Esteves, por ter sempre acreditado "que eu conseguiria", pela orientação rigorosa ( $\&$ bem-humorada) e pelas ótimas sugestões de tradução, incentivos sem os quais eu não teria concluído este estudo;

À Profa. Dra. Stella O. Tagnin, por suas sugestões no Exame de Qualificação.

Aos amigos,

Kim, de New Orleans, por ter me apresentado ao livro A Confederacy of Dunces e pela presteza em localizar e enviar material sobre a obra;

Maria Teresa \& Donato, amantes da literatura e da tradução, e amigos sempre dispostos a discutir e revisar este trabalho com carinho;

Nivaldo, Bel, Élide, Amélia, Luis, Gêi, Sheila, Ana (e família) e Maria Silvia, pelo apoio emocional e/ou nas tarefas do dia-a-dia;

Ao grupo de orientandos da Profa. Dra Lenita M. R. Esteves, que de "colegas de trabalho" tornaram-se ótimos amigos e grandes incentivadores. Em especial à Solange, por sua inestimável ajuda com os textos em francês.

Aos meus pais, Abdalla e Catharina, pelo apoio incondicional.

À secretária do DLM, Edith, por sua eficiência implacável. 
o câncer da sul humilde é minha lei

aqui sabotage não é viagem o que sei

então vai faz sei que Jesus é a luz

a humildade é que me conduz para o rap reproduz

o crime quem não é creme eu faço parte também

cada lugar um lugar cada lugar uma lei ok

só não dever para ninguém porém eu sei

respeito é para quem tem

(Sabotage, em Rap é Compromisso)

Enfim, também em termos lingüísticos, um bom tradutor deve ser sempre e acima de tudo, um homem de seu tempo.

(Dino Preti, em Tradução e Aceitabilidade Social das Formas Lingüísticas) 
RESUMO: Este trabalho tem por objetivo traduzir os diálogos do personagem Burma Jones, do romance $A$ Confederacy of Dunces, de autoria do norte-americano John Kennedy Toole (1937-1969). A caracterização da fala do personagem remete-se ao inglês não-padrão Black English Vernacular (BEV), fato que levanta questões acerca dos dialetos literários e da problemática de sua tradução. A obra de Toole é praticamente desconhecida dos brasileiros, senão por uma tradução restrita aos leitores do Círculo do Livro, feita por Cristina Boselli, na qual a fala de Jones não apresenta nenhum marcador dialetal, apenas registra um nível coloquial. Na introdução do trabalho, no Capítulo I, demonstro a relevância de se manter na tradução uma diferenciação entre os níveis de fala de cada personagem, em especial do negro Jones, ao examinar como o autor empregou a heterogeneidade lingüística a favor da caracterização dos personagens e da posição social que cada um ocupa na sociedade ficcional do livro. Estabelecida essa relação, considero, no Capítulo II, os dialetos literários em sua construção formal e nas implicações representativa, ideológica e humorística que resultam da presença desse recurso na obra literária. Nessa análise, destaco momentos de nossa literatura em que personagens negros receberam tratamento diferenciado nos diálogos, a fim de verificar como tem sido a representação ficcional da fala dos negros na literatura brasileira. No Capítulo III, no que concerne à teoria da tradução, aproveito a questão da tradução dialetal para enfatizar a intervenção "violenta" do tradutor na produção de sentido estético, ideológico e político, processo que se repete também na tradução em geral e sustenta-se nas teorias contemporâneas da tradução, em que os conceitos de "original" e "fidelidade" são questionados. Como conclusão, apresento a tradução comentada dos diálogos mais relevantes de Burma Jones.

Palavras-chaves: Literatura norte-americana; Literatura brasileira; Dialeto literário; Tradução dialetal; John Kennedy Toole. 
ABSTRACT: This paper aims to translate the dialogues of Burma Jones, a character from John Kennedy Toole's book A Confederacy of Dunces. This character's speech is a representation of the Black English Vernacular (BEV) style, which raises questions about the literary dialects and the problems involved in their translation. Toole's work is almost unknown to Brazilian readers, except for a translation by Cristina Boselli, distributed only to members of Círculo do Livro and therefore available to a limited readership. In that translation, Jone's speech is not presented with any trace of dialectal variation, being only marked as belonging to a colloquial register. Chapter I advocates for the relevance of preserving the translation of the different literary dialects, especially Burma Jones'. This is done through examining how the author employed the linguistic heterogeneity to stress the characters' peculiarities and the social position they occupy in the fictional society of the book. This relation being established, Chapter II considers the literary dialects in their formal construction and the representative, ideological and humorous effects they create in a fictional work. This analysis highlights works from Brazilian literature in which black character's speeches have received a different treatment, in order to verify how the authors have portrayed them. Chapter III addresses translation theory and emphasizes the translator's violent intervention, as s/he creates aesthetic, ideological and political meaning in any act of translation, and specially when translating literary dialects. This concept is supported by to some authors on contemporary translation theory, who challenge the concepts of "fidelity" and "original work". In conclusion, I present a dialectical translation of the most relevant dialogues of Burma Jones, followed by comments on my decisions.

Keywords: American Literature; Brazilian literature; Literary dialect; Dialectal translation; John Kennedy Toole. 


\section{ÍNDICE}

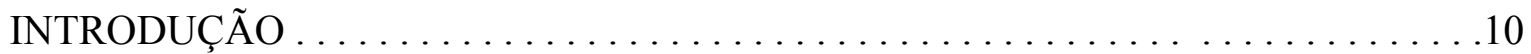

CAPÍTULO I - As sabotagens lingüísticas em A Confederacy of Dunces . . . . . . . . . 13

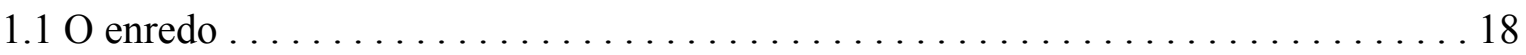

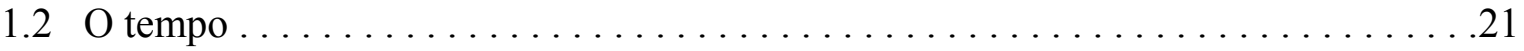

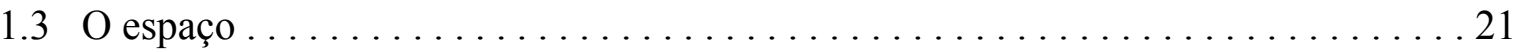

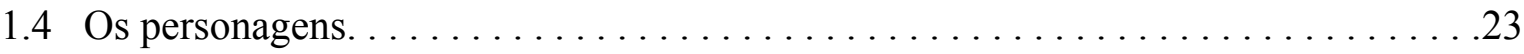

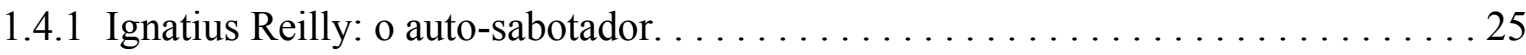

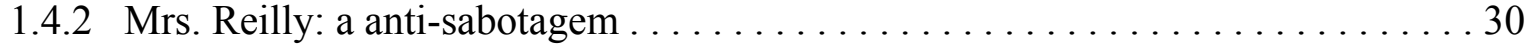

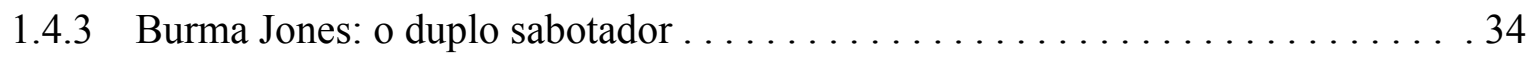

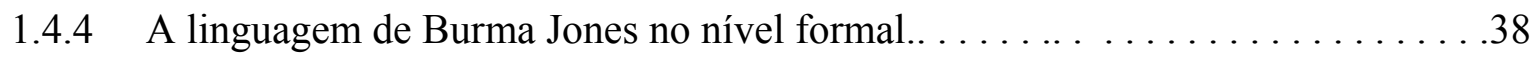

CAPÍTULO II - Dialeto Literário: forma e efeito $\ldots \ldots \ldots \ldots \ldots \ldots \ldots \ldots . \ldots 42$

2.1 A construção do dialeto literário. . . . . . . . . . . . . . . . . . . . . 43

2.2 A "língua de preto" ...................................... 49

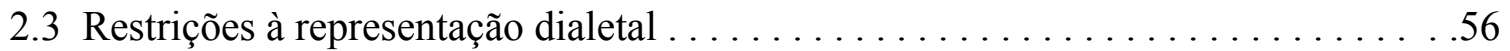

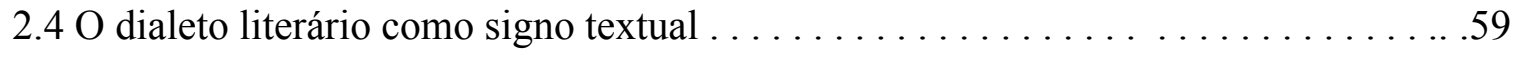

2.4.1. As funções identificadora, ideológica e humorística do dialeto literário. .......61 
CAPÍTULO III - Burma Jones: sabotagem traduzida $\ldots \ldots \ldots \ldots \ldots \ldots \ldots$

3.1 A ética na tradução dos dialetos literários $\ldots \ldots \ldots \ldots \ldots \ldots \ldots \ldots \ldots \ldots \ldots \ldots \ldots$

3.2 Proposta de tradução para Burma Jones . . . . . . . . . . . . . . 75

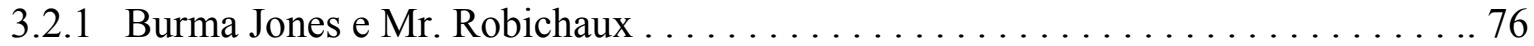

3.2 .2 Burma Jones e Lana Lee . . . . . . . . . . . . . . . . . . . . . . 83

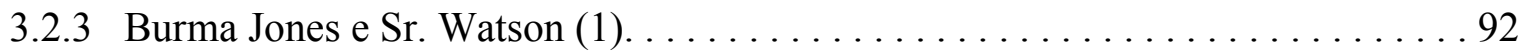

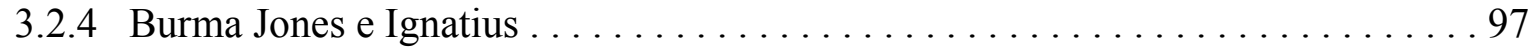

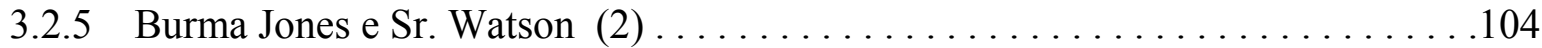

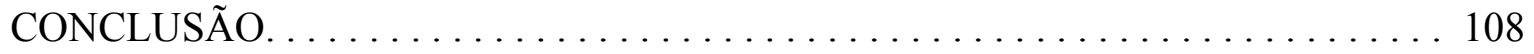

REFERÊNCIAS BIBLIOGRÁFICAS. . . . . . . . . . . . . . . . 110 


\section{$\underline{\text { INTRODUÇÃO }}$}

A idéia de traduzir para o português a obra A Confederacy of Dunces, do norteamericano John Kennedy Toole (1937-1969), surgiu à época em que eu concluía o curso de especialização em tradução nesta mesma instituição, a partir de uma necessidade pessoal, pois é um dos meus livros favoritos. Sentia-me bastante empolgada em levar a empreitada a cabo, mesmo tratando-se de uma obra vencedora do prêmio Pulitzer, em 1981. O grande desafio que se abria, além das cerca de 400 páginas que registram a magistralidade de Toole, era a tradução do diálogo de certas personagens que se expressam em inglês nãopadrão e ilustram a diversidade cultural e lingüística de New Orleans, cidade em que se ambienta a narrativa. Pareceu-me então que a obra seria um corpus adequado para discutir a tradução de dialetos literários, cuja problemática ainda não recebeu a devida atenção entre tradutores e estudiosos brasileiros da tradução (Sariam, 2002).

No romance, há uma grande variedade de dialetos, sendo o mais marcado dentre todos o do personagem negro Burma Jones. Essa peculiaridade, além de minha simpatia pelo personagem, tornou-o o objeto de meu interesse. A fala de Jones está construída com base em aspectos estigmatizados do dialeto não-padrão do Black English Vernacular, muitos dos quais se encontram nas descrições do sociolingüista William Labov (1972). A marcação dialetal é carregada, o que faz de Burma quase uma caricatura, não fosse seu discurso antiracista ser tão contundente. Ao analisar o jeito de falar do personagem e o seu papel de sabotador de sua patroa racista, foi possível traçar um paralelo entre a inserção de variedades lingüísticas no texto literário, que de certa forma é uma "sabotagem" contra a norma padrão que tradicionalmente dita a linguagem dos romances, e a função do personagem na narrativa. Foi possível estabelecer o mesmo paralelo em relação a dois outros personagens, o protagonista, Ignatius Reilly, e sua mãe, Irene Reilly, conforme demonstro na análise do romance, o que me sugeriu a idéia de nortear todo o trabalho em torno do termo sabotagem, na acepção de "agir astutamente contra (alguém ou algo)" (Houaiss, 2001).

Em sua valiosa dissertação de Mestrado sobre a tradução do romance epistolar The Color Purple, de Alice Walker (1982), em que as irmãs negras Celi e Netti se expressam num falar que remete ao BEV, Sariam defende a parceria entre sociolingüística e tradução 
na busca de soluções para a tradução dialetal. Este trabalho, no entanto, sugere um caminho diferente ao propor que valores como autenticidade e confiabilidade sejam associados menos ao grau de verossimilhança entre dialeto literário e dialeto real do que ao seu "efeito literário". Isso significa que o dialeto deve "funcionar" dentro dos limites do texto, espaço no qual auxilia na caracterização dos personagens e da sociedade em que se estrutura a narrativa.

Da mesma maneira que proponho uma revisão na análise dos dialetos literários, parece-me que a questão da tradução dialetal é um terreno fértil para a discussão e aplicação das idéias pós-modernas no âmbito da tradução, onde são redefinidas as noções de texto original e fidelidade. Para abordar esse tema, tomo como base o trabalho da pesquisadora canadense Gillian Lane-Mercier (1999), cuja proposta é a de superarmos o pensamento dualista que caracteriza uma considerável parcela dos estudos da tradução para finalmente aceitarmos que traduzir é um ato que envolve simultaneamente movimentos opostos, como perda e ganho, fidelidade e transformação, e sempre determinado historicamente. A pesquisadora transfere para as mãos do tradutor a responsabilidade política, ideológica e estética de suas escolhas durante o processo tradutório e, por conseguinte, do resultado de seu trabalho.

Para realizar a tradução que apresento ao final deste estudo, pareceu-me pertinente abordar a questão em três frentes. No Capítulo I, apresento, primeiramente, uma análise formal da obra, pouco conhecida no Brasil, enfocando o enredo, o espaço, o tempo e os personagens. Analiso o falar do protagonista Ignatius Reilly, de sua mãe, Irene Reilly e de Burma Jones. Em cada um procuro estabelecer a relevância dos dialetos literários na caracterização psicológica do personagem e quais suas implicações para o entendimento global da obra. O objetivo é salientar a importância de se manter, na tradução da obra, a heterogeneidade lingüística retratada por Toole.

Para prosseguir com a discussão, no Capítulo II abordo os dialetos literários em si, demonstrando como eles são elaborados e suas principais limitações, bem como as funções identificadora, ideológica e humorística que desempenham no texto. Ao mesmo tempo, ilustro com excertos de obras literárias como a fala do negro tem sido representada na literatura brasileira, desde sua origem, com a "língua de preto", em Portugal, no século XV, até nossa produção nacional mais recente. 
No Capítulo III, reflito sobre a ética do tradutor na tradução dialetal, e, por conseguinte, na tradução em geral, como sugere Lane-Mercier (1999). Discuto os valores de equivalência e texto original e apresento as críticas mais comuns que se mantêm presas a esses conceitos quando têm por alvo a tradução dialetal. Essa discussão também leva em conta as dicotomias apresentadas por Venuti $(1986,2002)$ e Berman (2003) sobre o papel do tradutor. Finalizo o capítulo com a minha tradução, acrescida de comentários, de cinco passagens de diálogos de Burma Jones com diferentes interlocutores. 


\section{CAPÍTULO I}

\section{AS SABOTAGENS LINGÜÍSTICAS EM A CONFEDERACY OF DUNCES}

Inicio este capítulo apresentando o romance $A$ Confederacy of Dunces, uma vez que os leitores brasileiros não estão familiarizados com o trabalho do escritor norte-americano John Kennedy Toole. Para tanto, realizo uma breve introdução à obra, analisando aspectos do enredo, do espaço e do tempo, explanação precedida de material crítico que considero relevante. Em seguida, concentro-me na linguagem dos personagens, demonstrando a gradação dialetal que permeia todos os diálogos da narrativa, cujos extremos estão personificados no falar do protagonista, Ignatius J. Reilly, e do negro Burma Jones.

Em relação à representação da linguagem de Jones, observo sua construção estilística, salientando os aspectos fonéticos e gramaticais atualizados por Toole em sua representação do Black English Vernacular (BEV, doravante). Deixo para o capítulo seguinte a análise das funções humorística, identificadora e ideológica que tal representação dialetal assume no texto, quando abordarei o tema específico do dialeto literário. O presente capítulo objetiva salientar a relevância de se manter na tradução alguma forma de diferenciação entre as falas dos personagens, em especial, a de Burma Jones.

John Kennedy Toole nasceu em New Orleans, em 1937, de pais americanos descendentes de irlandeses, franceses e espanhóis. Graduou-se em língua inglesa pela Universidade Tulane, obtendo grau de Mestre em Literatura Inglesa pela Universidade de Columbia. Toole exerceu o magistério em diversas oportunidades, inclusive em Porto Rico, onde foi enviado pelo exército norte-americano para ministrar aulas de inglês aos soldados locais. Sua experiência no exterior The foi muito importante, pois é o momento em que dispõe de "time, detachment, security, and privacy" (Nevils; Hardy, 2001, pp.137-138), para dedicar-se a escrever A Confederacy of Dunces. De volta aos EUA, Toole fixa residência em New Orleans, onde volta a morar com os pais e a dar aulas. A vida familiar problemática e as tentativas fracassadas de publicar esse romance levam Toole ao suicídio, em 1969, aos 31 anos, quando não havia publicado nenhum de seus dois romances. A Confederacy of Dunces saiu apenas onze anos após a morte do autor, ao 
passo que The Neon Bible, romance escrito ainda na adolescência, foi lançado em 1989, ao fim de uma longa batalha judicial familiar pelos direitos autorais da obra.

Embora o caminho de $A$ Confederacy of Dunces até o prelo não tenha sido sem obstáculos - que por quase duas décadas postergaram sua edição, além de fomentar a depressão e o suicídio do autor - Toole empenhou-se na publicação da obra tão logo terminou de escrevê-la. De volta a New Orleans, em fevereiro de 1964, após o período a serviço do exército norte-americano na América Central, o escritor enviou o manuscrito à editora Simon and Schuster, um pequeno negócio familiar baseado em Nova York. Pelos dois anos seguintes, Toole e o editor sênior da casa Robert Gottlieb entrariam numa infrutífera troca de cartas e telefonemas, sem nunca chegarem a um acordo sobre os "retoques" que Toole deveria efetuar antes de A Confederacy of Dunces ser publicado. Ao editor Robert Gottlieb incomodava o encadeamento dos fatos e os diversos fios narrativos; sobretudo, Gottlieb cobrava do autor "a point to everything that you have on the book, a real point, not just amusingness that's forced to figure itself out." (Nevils; Hardy, 2001, p.126). Essa “falta de sentido", segundo a análisedo editor, seria a razão pela qual o livro jamais sairia pela Simon and Schuster. O resultado da negociação "was a painful experience for editor and author, ending unhappily for both of them”. (Ibidem, p.124)

Em 1976, a fortuna do livro seria outra, graças à persistência da mãe de Toole. Aproveitando-se da presença do escritor Walker Percy ${ }^{1}$ em New Orleans, o qual oferecia um curso de literatura na Universidade Loyola, Thelma Toole, após várias recusas do escritor em recebê-la, consegue driblar a barreira do escritório de Percy e entregar-lhe pessoalmente o manuscrito surrado de $A$ Confederacy of Dunces. Certo de que as primeiras páginas seriam ruins o suficiente para desestimulá-lo da leitura, Percy aceitou a tarefa. Contra as suas expectativas, gostou do que leu:

I have finished reading John Toole's A CONFEDERACY OF DUNCES and I find it an astonishingly original and talented novel. No doubt there are many things wrong with it - too much dialogue here, not enough action there - but on the whole I find it an extraordinary display of a mordant humor, wild satire, and an uncanny ear for New Orleans speech and a sharp eye for place (I don't know any novel which has captured the peculiar flavor of New Orleans neighborhoods nearly as well). (Ibidem, p.188)

\footnotetext{
${ }^{1}$ Autor de The Moviegoer (1961), ganhador do National Book Award, em 1962.
} 
Com um aliado de peso em sua defesa, A Confederacy of Dunces foi aceito para publicação pela editora da Universidade da Louisiana (EUA), sendo lançado em 1980. Desde então a popularidade da obra segue num crescendo. Atualmente, o público de mais de dezoito países já teve a oportunidade de divertir-se com as peripécias de Ignatius Reilly e um leque de personagens habilmente elaborados por Toole, cujas vidas são afetadas pelas maluquices do protagonista. Prazer, no entanto, ainda não compartilhado pelo grande público brasileiro, uma vez que a única tradução brasileira, assinada por Cristina Bosseli, chegou às mãos apenas dos associados do Círculo do Livro.

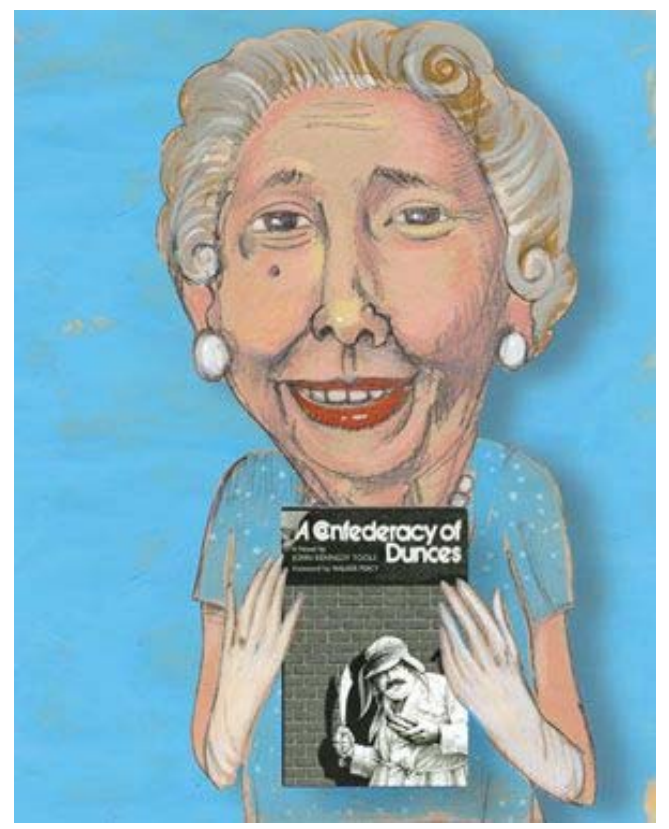

Ponto para Thelma Toole

O caráter desconexo da estrutura do romance apontado pelo editor de New York é refutado por Pattenson e Sauret. Na opinião dos autores, A Confederacy of Dunces é um "elaborately designed work of fiction, with numerous subplots spinning off from the main line of action and repeatedly doubling back into each other" (Pattenson; Sauret, 1993, p.77), cabendo às peripécias de Ignatius a condução do enredo central. Essa urdidura recebe na análise de Kline um destaque ainda maior: 
The pleasure principle in Tool's novel derives from continuity, no matter how interrupted, cinematographically dislocated, or fragmented it may appear. While cause-effect determinism has become suspect in the age o postmodernism, Toole's relatively traditional approach to comic causality situates de enjoyment of fiction within continuity. (Kline, 1999, p. 284)

Se na estrutura do romance a comicidade acontece pela causalidade do enredo central e de seus braços auxiliares, o que resulta numa continuidade de ação, no nível do discurso o choque entre a cultura medieval apregoada pelo narrador e a sociedade em que ele está inserido resulta num anacronismo duplo, pois reforçado pela visão do leitor, este inserido num mundo muito mais próximo ao da vida "real" de Ignatius que ao de sua visão de mundo:

The humor in the novel, and it exists in abundance, derives from the panorama of incongruities between actions and expectations with which Toole permeates the novel. Toole spotlights the idiosyncratic nature of Ignatius Reilly's perspective on reality and balances it with the equally chronocentric - and culturally idiosyncratic - perspective of the modern reader. (Bell, 1988, p. 16)

A Confederacy of Dunces traz como protagonista o ardente defensor da sociedade medieval Ignatius Reilly, personagem, na opinião de Walker Percy "without progenitor in any literature I know of - slob extraordinary, a mad Oliver Hardy, a fat Don Quixote, a perverse Thomas Aquinas rolled into one." (Toole, 1987, p. 4) ${ }^{2}$. Ignatius J. Reilly, 30, é um obeso e fétido medievalista, disposto a fazer de sua vida uma cruzada contra os valores da sociedade moderna, pois como ele próprio observa, " with the breakdown of the Medieval system, the gods of Chaos, Lunacy, and Bad Taste gained ascendancy" (ACD, p. 40). Mestre em estudos medievais, o protagonista opõe-se a tudo o que se refere ao mundo moderno, e apesar de seu campo de batalha ser qualquer lugar onde coloque os pés, Ignatius gosta mesmo é de afundar-se nos lençóis encardidos de sua cama, de onde escreve diários "absurdly self-aggrandizing" (Pattenson; Sauret, 1983, p. 78) em meio a ereções, bofadas e constantes crises de fechamento da válvula pilórica. McNeil salienta que, graças a Ignatius, a obra A Confederacy of Dunces é um subgênero da sátira, denominada "sátira reversa":

Seeing twentieth-century America as the culminating horror of an abominable degeneration that began with Renaissance, Ignatius J. Reilly - the novel comic hero - is a brilliant embodiment of reverse satire because he epitomizes the very perversions against which he rages. Whenever he is not condemning the modern world for its obscene "excess", he fattens

\footnotetext{
${ }^{2}$ Refiro-me sempre à edição de 1987 de $A$ Confederacy of Dunces, doravante ACD.
} 
his already obese body with a steady diet of hot-dogs, Dr. Nut (a soft-drink), and bakery cakes. (McNeil, 1984-1985, p. 35)

Em Ignatius instaura-se a diferença porque o protagonista é indesculpavelmente hipócrita ele atira para todos os lados e no próprio pé. Tal comportamento o diferencia de outros heróis cômicos em defesa de valores como tradição, moralidade e dignidade pertencentes à tradição literária do Sul dos EUA, como o personagem Sut Lovingood, de George Washington Harris (Ruppersburg, 1986, p. 118), uma vez que em Ignatius não se pode confiar. Por outro lado, de acordo com Ruppersburg (op.cit.), A Confederacy of Dunces segue essa tradição ao apresentar ingredientes dos romances do final do século XIX, conhecidos por pertencerem à escola da cor local. Na obra de Toole destacam-se a vívida descrição dos lugares, a variedade étnica retratada e os dialetos ilustrados, aspectos que dão ao romance o colorido inconfundível da cidade onde a narrativa está ambientada:

Toole evokes the lower middle-class Catholic atmosphere of his setting by including numerous authentic details of New Orleans life. He describes the city exactly as it existed in the early 1960s, with no apparent embellishment of the facts. The streets named and places described actually exist. (...) The dialects of Mrs. Reilly, Burma Jones, Santa Battaglia, and other characters also contribute to the evocative sense of place. (Ruppersburg, 1986, p.119)

O talento de Toole para recriar as diversas variantes lingüísticas presentes em New Orleans é um dos pontos altos do romance. Pelos elogios recebidos, percebe-se que Toole conferiu, em alguma medida, exatidão à recriação dos falares locais. Portanto, é de se esperar que os dialetos literários em A Confederacy of Dunces resultem de um projeto autoral fundamentado na mimese, fato corroborado por outro talento notável do escritor, o de imitar as pessoas. As aulas de Literatura Inglesa, ministradas por ele no Colégio Dominicano de New Orleans, no decorrer de 1964, eram das mais populares entre os estudantes, e não sem motivo, pois como recorda um deles "he was hysterically funny and could make the class weep with laughter while he barely cracked a smile". (Nevil; Hardy, op.cit., p. 130)

Mas se a princípio os falares de New Orleans estão na obra com o objetivo de ilustrar um determinado espaço geográfico e seus habitantes, é possível afirmar também que os dialetos apareçam por uma necessidade intrínseca à narrativa. Num viés interessante de análise literária, Fennell e Bennett utilizam o instrumental da sociolingüística para demonstrar como Ignatius faz uso da língua com a finalidade de manter-se à margem de sua comunidade de fala e dos 
"dunces" à sua volta. A pretensa superioridade de caráter e a escolaridade ostentadas por Ignatius são reforçadas em seu desempenho lingüístico, cujo objetivo é mantê-lo seguro em sua "comunidade de um só". Ainda mais relevante para este estudo é a afirmação das autoras de que

There is a continuum of dialect use in the novel, with an illiterate black ex-vagrant night-club floor-sweeper on one end, Ignatius J. Reilly on the other, and various other significant characters in between (Fennell; Bennett, 1991, p. 373).

O argumento é um gancho poderoso na defesa de que o "unabashed use of Negro dialect" (Codrescu, 2000, p. 4) não passe por um processo homogeneizador na tradução, pois, além de estar associado à realidade da cidade de New Orleans, responde a uma necessidade de articulação dos personagens entre si. Como veremos a seguir, a taxa de saturação dos marcadores dialetais está relacionada à caracterização do personagem e do papel desempenhado por ele no enredo. Portanto, é justo afirmar que a defesa de manter-se na tradução algum nível de diferenciação

lingüística nos diálogos é válida para todos os outros personagens da escala dialetal entre os extremos de Ignatius e Burma Jones.

\subsection{0 enredo}

Ignatius vive às custas da mãe num bairro modesto de New Orleans sem demonstrar a menor vontade de entrar para o mundo dos adultos. Sempre na companhia de seu relógio de pulso com a figura do Mickey, suas atividades resumem-se a ficar na cama, ir ao cinema ou assistir à televisão, enquanto se empanturra de refrigerante e bolo. Nos momentos de depressão, o herói clama pela justiça da Roda da Fortuna, embora quem bata à sua porta não seja a "blind, heedless goddess" (ACD, p. 42) e sim Irene Reilly, sua sofredora mãe, vítima de constante abuso psicológico por parte do filho e chegada a um bom copo. Apertada financeiramente em decorrência de uma dívida contraída num acidente automobilístico, Irene Reilly dá um basta à vida parasitária do filho ao exigir que ele comece a trazer dinheiro para casa. Deparando-se com a "perversion of having to GO TO WORK" (ACD, p.41), Ignatius emprega-se, primeiramente, numa decaída fábrica de calças, onde lidera os operários negros na fracassada "Crusade for Moorish Dignity" (ACD, p.149). Colocado no olho da rua, o protagonista passa a vender cachorro-quente metido numa fantasia de pirata. Certa tarde, ao perambular com seu carrinho de 
lanches, Ignatius entra em contato com o contrabandista de figurinhas pornográficas George, de quem adquire a foto de uma mulher nua cuja sugestão de "onanism with the piece of chalk intrigued Ignatius" (ACD, p. 300). O rosto da modelo está oculto pelo livro A Consolação da Filosofia, de Boetius, o livro de cabeceira do medievalista. Certo de que a modelo é "some destitute woman intellectual (...) doing anything for a dollar" (ACD, p. 300), Ignatius decide resgatá-la. Um endereço anotado às pressas do pacote de material ilícito leva-o à boate Noite do Prazer. Jones, o faxineiro negro do inferninho, que vinha aguardando uma oportunidade para sabotar a patroa racista, facilita a entrada de Ignatius na boate, onde ele é atacado pelo cockatoo da dançarina, que confunde o brinco de pirata do protagonista com as argolas do vestido que a ave deveria abrir durante o striptease da dançarina Harlett O'Hara. Ignatius é forçado a deixar o local às carreiras. Na confusão que se segue do lado de fora, o protagonista é salvo por Jones de ser atropelado por um ônibus, estatelando-se no chão, inconsciente. No dia seguinte, os jornais estampam, na primeira página, a foto de Ignatius caído em frente à boate, com o nome ligado à rede de contrabandistas encabeçada pela patroa de Jones, Lana Lee, a verdadeira modelo da foto. Ao ver a foto do filho, Irene Reilly convence-se de que ele, na verdade, é um comunista e chama a ambulância do manicômio público de New Orleans para recolhê-lo. Ignatius, no entanto, consegue escapar, sendo resgatado por sua ex-namorada, a beatnik Myrna Minkoff, com quem mantém uma intensa e conturbada correspondência ao longo do romance. Os dois partem rumo a New York sob o olhar otimista do narrador: "Now that Fortuna had saved him from one cycle, where would she spin him now? The new cycle would be so different from anything he had ever known" (ACD, p.405).

À linearidade narrativa conjugam-se quatro subenredos ligados diretamente a Ignatius, relacionando-se entre si por meio de um ou mais personagens, como sugerido por Patteson e Sauret (1982). De acordo com os autores, a força vulcânica de Ignatius expande-se em quatro subenredos dominantes, centrados em Irene Reilly, no policial Mancuso e nos espaços da boate Noite do Prazer e da fábrica Levy Pants. Irene Reilly conecta-se a Mancuso logo no segundo capítulo, quando este a procura para comunicar-lhe a dívida do acidente automobilístico. A visita do policial tem seu lado positivo, pois ele será o responsável por apresentar a Irene Reilly seus futuros amigos e defensores contra a tirania de Ignatius: Santa Bataglia, tia do policial, e Mr. Robichaux. O círculo de amigos de Irene Reilly passa então a ser composto por Santa Bataglia, "a stocky woman with kinky gray hair" (ACD, pp.114-115), o policial Mancuso, que perambula 
pela cidade como punição por seu deprimente desempenho profissional, fantasiado em "ballet tights and a yellow sweater" (ACD, p. 38), e o ferroviário aposentado Mr. Robichaux, membro do clube "Older Age" (ACD, p. 26) e pretendente de Irene Reilly. Todos, incluindo Irene, representam "the lower-class, uneducated descendants of Irish, Italian and French immigrants who have settled in New Orleans" (Daigrepont, 1982, p.76). A outra ligação com o lar dos Reilly, mediada por Mr. Levy, é a fábrica Levy Pants. Ao trabalhar na fábrica de calças, Ignatius não apenas promove a insurgência, como também envia uma missiva grosseira, em nome do proprietário, a um dos parceiros comerciais da Levy Pants, o que gera uma ação indenizatória por parte do ofendido. Na busca do verdadeiro autor da ofensa, Mr. Levy entra em contato com os Reilly, mas acaba por simpatizar com Ignatius, transferindo para Miss Trixe, a senil secretária da fábrica, a responsabilidade pela autoria da carta. A fábrica de calças, por sua vez, liga-se à boate Noite do Prazer por meio do personagem de Burma Jones. O jovem negro conhece um dos operários da Levy, e recebe a informação de que um sujeito "one-hunner-percen freak" (ACD, p.144) está tramando uma sabotagem contra a fábrica. Dessa maneira, quando Ignatius aparece na boate, Burma Jones reconhece no gordo excêntrico a chance de sabotar Lana Lee, "the novel's greatest cynic" (Patteson; Sauret, 1982, p.81).

No quarto vértice, temos a própria boate Noite do Prazer, espaço ligado à fábrica Levy Pants por meio de Burma Jones e ao policial Mancuso pela ação do contrabandista adolescente George. A boate Noite do Prazer é o espaço de Jones por excelência, onde ele "unenthusiastically sweeps the floor" (ibidem, p. 79), por um salário que Lana Lee afirma não pagaria "a blind Eskimo" (ACD, p. 119). George, o adolescente vestido em "tight trousers that bulged offensively in the crotch" (ACD, 173), comandado pela "Nazi" Lana Lee, entra em contato com Mancuso quando ambos se encontram no banheiro da rodoviária, onde Mancuso faz plantão. O policial está escondido num dos banheiros lendo A Consolação da Filosofia, de Boetius, livro emprestado por Ignatius, quando observa George em atitude suspeita. Ao tentar prendê-lo, é agredido pelo adolescente, que the bate com o livro na cabeça e foge levando o exemplar. Será por essa via torta que o livro predileto de Ignatius aparecerá na foto pornográfica ocultando a identidade de Lana Lee.

No final da narrativa, o personagem central de cada subenredo receberá o mesmo desfecho libertador reservado a Ignatius. Irene Reilly consegue dar seu grito de liberdade ao anunciar o casamento com Mr. Robichaux e dizer ao filho "Go to hell, Ignatius" (ACD, p.375). Mr. Levy 
liberta-se da esposa opressora e da lembrança do pai, igualmente opressor, e decide-se por mudar a linha de confecção para bermudas, iniciando uma nova fase com a Levy Shorts. O policial Mancuso, após desmantelar "the city's most active high school pornography racket."(ACD, p. 355), deixa de lado o passado humilhante das patrulhas fantasiadas para receber uma merecida promoção. Já Burma Jones, um dos “"undercover' agents in the novel” (Kline, 1999, p. 287), ao lado de Mancuso, colhe finalmente os louros por sua melhor faxina, "Jones subversion finally wins him an award as the savior of a city that, with Ignatius removed and Jone's corrupt employer Lana Lee in jail, is comically cleansed" (Mackethan, 1994, p. 38), sendo agraciado por Mr. Levy com um novo emprego.

\subsection{0 tempo}

O tempo da narrativa é linear, e, embora não haja nenhuma referência a datas que oriente o leitor, sua passagem é percebida pelo encadeamento dos fatos no enredo, em que encontramos pontuações temporais do tipo "he saw the sun beginning to descent over the Mississipi" (ACD, p.14) ou "Twilight was settling around the Night of Joy" (ACD, p.29). É razoável sugerir que o enredo desenrola-se em um mês.

\subsection{Ospaço}

A importância atribuída à ambientação não é casual em A Confederacy of Dunces. O próprio autor recorreu a duas das três epígrafes do livro para ilustrar a contribuição da diversidade étnica e cultural na formação da cidade de New Orleans, aspectos presentes na obra. As epígrafes apresentadas funcionam como uma porta de entrada para a atmosfera complexa do local. New Orleans é um caldeirão de culturas, e seus habitantes manifestam essa mistura em diversos aspectos da vida, inclusive na linguagem. A descrição minuciosa e precisa dos lugares é um reforço na realização plena da ambientação, bem como o emprego de dialetos.

Há quem veja na vida da cidade moderna o tema central da obra (Ruppersburg, 1986, p. 120), e o espaço urbano como um catalisador de personagens "suffering the modern disease of alienation" (Mackethan, 1994, p.29), mal que afeta principalmente Ignatius. Mas, para o nosso herói cômico, New Orleans vem ao encontro de suas preocupações e contradições. Se, por um lado, ele defende que "outside of the city limits the heart of darkness, the true wasteland begins" (ACD, p.22), por outro, não hesita em elencar a "fauna" condenável que habita New Orleans: 
This city is famous for its gamblers, prostitutes, exhibitionists, anti-Christ, alcoholics, sodomites, drug addicts, fetishists, onanists, pornographers, frauds, jades, litterbugs, and lesbians, all of whom are only too well protected by graft. (ACD, p.15)

A decadência moral apontada por Ignatius pode ser rastreada na própria origem da cidade. Colonizada primeiramente por franceses, em 1682, a região recebeu o nome de Louisiana em homenagem ao Rei Sol, Luís XIV. Em 1727, quando a vida estava difícil naquele terreno pantanoso habitado por jacarés e varrido por furacões, o governo francês, na busca de acalmar os ânimos dos colonos, decide tirar 88 mulheres das prisões parisienses e transformá-las em esposas na terra nova. Muitas dessas mulheres eram prostitutas que foram à colônia acompanhadas de religiosas. Todas caíram nas mãos dos colonos, e dessa união nasceu a relação duradoura entre New Orleans e a devassidão.

Ignatius também coloca o dedo em outro tipo de "ferida" da cidade, a decadência material, que se associa a fatos posteriores da história de New Orleans. Em fins do século XVIII, a Louisiana passou de colônia francesa a domínio espanhol, num acordo entre as coroas, selado nos palácios europeus (os moradores da colônia levariam quatro anos para saber que deviam lealdade a outro rei). Tal situação perdurou por apenas três décadas e a região voltou à coroa francesa em fins do mesmo século. Em 1803, a Louisiana é finalmente vendida por Napoleão à nova união americana, recentemente liberta, em 1776. Nesse vaivém formou-se uma cidade singular, com uma população de franceses, espanhóis, anglo-saxões, africanos e índios. New Orleans chegou a ocupar a posição de segunda cidade mais rica dos EUA devido ao movimento portuário, posição perdida posteriormente para New York. Como sugerem Pattenson e Sauret, em A Confederacy of Dunces a formação cultural e econômica da cidade são primordiais para o protagonista, oferecendo-lhe alívio e danação:

The Germanic, industrial side of New Orleans' heritage can be associated with all that has gone wrong with European civilization since the discovery of 'progress', while the city's links to the Mediterranean world suggest another, more sensual, kind of decadence. Ignatius needs both varieties of decadence - materialistic and sensual as something to indulge and against which to react. (Pattenson; Sauret, 1983, p. 81) 
Outro aspecto importante relacionado à ambientação está na relação já citada entre a obra e os romances da escola da cor local. O movimento americano da cor local originou-se no período posterior à Guerra Civil (1860-65), quando "the aura of never-never-land exoticism began to spread over the land of the Lost Cause" (Simpson, 1992, p.80). O resultado foi que à dependência econômica do sul em relação ao norte somou-se a dependência cultural. Por contraditório que pareça, a dependência cultural aumentou, porque a literatura sulista descobriuse produtora de um tipo de romance muito bem aceito entre os leitores de toda a nação, aqueles em que o passado era romantizado e retratava o "Old South". New Orleans, localizada no "Deep South”, torna-se o cenário por excelência da ambientação literária pintada em tais romances:

No product the southern writers turned out, moreover, was more eminently exportable than a story set in the city that even before the war had attracted attention as the most exotic of the South. Now, through an image nurtured by a whole group of writers - Cable, Chopin, Lafcadio Hearn, Grance King, Ruth McEnery Stuart - New Orleans unquestionably afforded the most exotic setting, rural or urban, in the whole nation. (Ibidem, p.82)

Embora em $A$ Confederacy of Dunces a ambientação não seja o personagem principal da narrativa - elemento característico dos romances da cor local - a descrição detalhada, e de certa forma realista, é um ponto importante de confluência desse tipo de literatura com a produzida por Toole. Podemos observar a preocupação do autor em descrever, por exemplo, os locais por onde os personagens circulam. Os Reillys moram em uma "declining neighborhood”, espremida entre a St. Charles Avenue e o rio Mississippi, com casas "built in the 1880s and 90s, wooden Gothic and Gilded Aged relics that dripped carving and scrollwork" (ACD, 48), onde habitações maiores "had become impromptu apartment buildings, their porches converted into additional rooms" (ACD, 48). A falta de privacidade é marcada no romance pela intromissão constante da vizinha dos Reilly, sempre reclamando de Ignatius.

Burma Jones, por sua vez, quando não está na Noite do Prazer, é encontrado no Mattie's Ramble Inn, uma "combination [of] bar and grocery" (ACD, 141), situado "on a corner in the Carollton section of the city where, after run parallel for six or seven miles, St. Charles Avenue and the Mississippi River meet and the avenue ends" (ACD, 141). O bairro é descrito como "an old rural town", que sofre com o mau cheiro de uma destilaria situada às margens do Rio Mississippi; Mattie's retrata todas as construções do quarteirão, "it was low, unpainted, imperfectly vertical” (ACD, 141). 


\subsection{Os personagens}

Todos os personagens em A Confederacy of Dunces apresentam grande potencial cômico, qualidade que também reside na manipulação autoral de conceitos sociolingüísticos, sendo o de maior visibilidade, neste estudo, o de variação lingüística. É sob esse prisma que apresentarei o modo de falar de Ignatius, Burma Jones e Mrs. Reilly. Escolhi os três personagens por sua relevância na narrativa e o grau de saturação das marcas dialetais neles verificados. Na figura elaborada por Fennell e Bennett, Ignatius ocupa o topo da escala da língua padrão, ao passo que, no extremo oposto, estão os falantes que fazem uso do inglês "menos" padrão, Mrs. Reilly e Burma Jones:

$\begin{array}{ll}\text { Most Nonstandard } & \text { Jones } \\ \text { Mrs. Reilly } & \text { Santa Battaglia } \\ \text { Darlene } \\ \text { Mr. Clyde } \\ \text { Mr. Robichaux Robichaux } \\ \text { Patrolman Mancuso } \\ \text { Mrs. Levy } \\ \text { Mr. Levy } \\ \text { Lana Lee } \\ \text { Dorian Greene } \\ \text { Standard } & \text { Myrna Minkoff } \\ & \text { Ignatius J. Reilly }\end{array}$

Legenda: A Continuum of Dialect Use in A Confederacy of Dunces. Fonte: Fennell; Bennett, op. cit., p.373.

Em Burma Jones e Mrs. Reilly, a identificação das variantes socioculturais recriadas por Toole não oferece dificuldade. O próprio autor sinalizou-as em epígrafes e informações fornecidas pelo narrador. No caso de Burma Jones, a primeira fala do personagem é precedida da seguinte descrição: "a young black man, eyeless behind spaceage sunglasses" ( ACD, p. 25), 
artifício que prepara o leitor para a recepção de um falar diferente, esteja ele concretamente presente no diálogo que se segue ou que terá de imaginar. Logo após a primeira fala de Irene Reilly, recebemos do narrador a explicação de que "Mrs. Reilly called in that accent that occurs south of New Jersey only in New Orleans, that Hoboken near the Gulf of Mexico" (ACD, p.16). Vale lembrar que, para esse falar "forasteiro", o leitor já havia sido alertado em uma das epígrafes:

There is a New Orleans accent associated with downtown New Orleans, particularly with the German and Irish Third Ward, that is hard to distinguish from the accent of Hoboken, Jersey City, and Astoria, Long Island, where the Al Smith inflection, extinct in Manhattan, has taken refuge. The reason, as you might expect, is that the same stocks that brought the accent to Manhattan imposed it on New Orleans. (ACD, p. 11)

Burma e Irene Reilly encabeçam dois grupos distintos de falar dialetal. Todos os negros do romance, os operários da fábrica Levy Pants e o dono do bar freqüentado por Jones, falam de maneira similar a Jones, ao passo que os amigos de boliche de Mrs. Reilly apresentam marcas de recriação dialetal similares às dela. Já a caracterização lingüística de Ignatius segue por outra via. Não há nos diálogos de Ignatius rastros de um falar marcado por sua origem étnica, mas sim do emprego do dialeto culto da língua em todas as situações de interação. Ao agir astutamente contra seus interlocutores para afirmar sua superioridade intelectual e de caráter, o protagonista acaba por isolar-se socialmente.

\section{Ignatius, 0 auto-sabotador}

A linguagem de Ignatius reflete sua obstinação em manter-se à parte do mundo e das pessoas que o cercam. O ("mau”) comportamento lingüístico do protagonista revela objetivos e estratégias pré-estabelecidas, como observam Fennell e Bennett:

Ignatius's contempt comes through most clearly in his attempt to differentiate himself linguistically from his social peers. Determined not to communicate with anybody any more than is essencial to remain in minimal contact, Ignatius aims to seal himself off from the other characters in a speech community of one, consistently employing verbal obfuscation and

\footnotetext{
${ }^{3} \mathrm{O}$ conceito de fala forasteira é de Azevedo (2003) e representa "a maneira de falar de imigrantes, viajantes, exilados e outros elementos alienígenas" (p.81).
} 
breaching linguistic conventions in order to stifle communication with those he considers inferior. (Fennell; Bennett, 1991, pp. 372-373)

Segundo as autoras, o conceito sociolingüístico de comunidade de fala, que envolve, grosso modo, "the ideas of shared linguistic norms, common locality, and more or less frequent primary interaction" (ibidem, p. 373), é central para o entendimento do personagem. O esperado, dentro de uma comunidade, é que os interlocutores usem a língua visando à comunicação e à integração no grupo social. Com Ignatius ocorre a quebra dessa expectativa. O protagonista não faz o menor esforço para integrar-se à sua comunidade, muito ao contrário. Na busca de isolamento, Ignatius, por exemplo, não poupa críticas ao desempenho lingüístico dos outros personagens, ao mesmo tempo em que sua performance é prestigiada por eles. A questão do prestígio lingüístico, noção que parece ser consciente em Ignatius, mas inconsciente nos outros personagens, está presente, por exemplo, na passagem em que o protagonista encontra-se na boate Noite do Prazer, na companhia da mãe e da candidata à dançarina exótica Harla O'Hara:

I bet you cook good, huh? Darlene asked.

"Mother doesn't cook", Ignatius said dogmatically. "She burns."

"I used to cook when I was married," Darlene told them. "I sort of used a lot of canned stuff, though. I like that Spanish rice they got and that spaghetti with tomato gravy."

"Canned food is a perversion," Ignatius said. "I suspect that it is ultimately very damaging to the soul."

"Lord, my elbow's starting up again," Mrs. Reilly sighed.

"Please, I am speaking," her son told her. "I never eat canned food. I did once, and I could feel my intestines starting to atrophy."

"You got a good education," Darlene said.

"Ignatius graduated from college. Then he stuck around there for four more years to get his master's degree. Ignatius graduated smarted."

"'Graduated smart,"” Ignatius repeated with some pique. "Please, define your terms. Exactly what do you mean by 'graduated smart."” (ACD, p.33)

Numa sociedade, a língua funciona "como uma marca social de um grupo, como um elemento identificador, à semelhança de um vestuário" (Preti, 2004, p.13); portanto, quando Ignatius emprega a palavra atrophy, Darlene reconhece um símbolo de prestígio lingüístico, 
inferindo que ele possui um grau de escolaridade elevado. Fennell e Bennett, com base nas máximas de Grice, comentam que, em sua busca de isolamento, Ignatius fere a máxima da relação ao trocar de assunto bruscamente, a máxima da polidez ao ser extremamente rude com os interlocutores e a máxima de modo, ao ser obscuro e ambíguo, pois dá preferência a palavras cujos significados poucos conhecem. A conversação seguinte exemplifica como Ignatius falha em informar o que lhe é perguntado, atropelando a máxima de quantidade. Esse item da conversação cooperativa é transgredido na transmissão de informações e idéias simples por meio de um excesso de palavras que cansam o interlocutor e das quais pouco se aproveita. Um exemplo da verborragia de Ignatius pode ser encontrado na defesa que ele faz de seu hábito de viver enfurnado num quarto fétido:

Mrs. Reilly threw herself against the unpainted wood.

"Well, don’t break the door," he said finally and, after a few moments, the bolt slid open.

"Ignatius, what's all this trash on the floor?"

"That's my worldview that you see. It still must be incorporated into a whole, so be careful where you step."

"And all that shutters closed. Ignatius! It's still light outside."

"My being is not without its Proustian elements," Ignatius said from the bed, to which he had quickly returned. "Oh, my stomach."

"It smells terrible in here."

"Well, what do you expect? The human body, when confined, produces certain odors which we tend to forget in this age of deodorants and other perversions. Actually, I find the atmosphere of this room rather comforting. Schiller needed the scent of apples rotting in his desk in order to write. I, too, have my needs. You may remember that Mark Twain preferred to lie supinely in bed while composing those rather dated and boring efforts which contemporary scholars try to prove meaningful. Veneration of Mark Twain is one of the roots of our current intellectual stalemate." (ACD, p.59)

Quanto às variantes lingüísticas, é possível apontar a impropriedade do uso da modalidade culta da língua em situações informais de comunicação. Ignatius, em sua busca de isolamento social, fala como se dialogasse consigo mesmo, fazendo uso de um léxico demasiado formal para 
as situações de interação. Esse é outro elemento de reforço cômico, pois o comportamento de Ignatius contraria a expectativa que se tem daqueles que detêm o domínio da língua culta:

São os falantes cultos, por certo, os que possuem maior consciência da necessidade de variarem a sua linguagem, em função das situações de interação diversas. São eles que, em razão de sua cultura lingüística, estão aptos a empregar a linguagem, segundo seus vários usos, adequando suas formas, empregando-as mais próximas ou mais distantes das regras da gramática escrita tradicional, de acordo com o grau de cultura de seus interlocutores, com o status, a idade, a escolaridade dos mesmos e o próprio tema da conversação. (Preti, 2004, p.14)

Ignatius, curiosamente, não flexibiliza sua linguagem em momento algum. Ele mantém sempre o mesmo padrão de fala, espesso na formalidade e ralo no sentido. Na cena abaixo, Irene Reilly acaba de receber a conta do acidente automobilístico, mãe e filho conversam na cozinha da casa em companhia do policial Mancuso. Ignatius dá preferência a palavras de origem latina e tempos verbais geralmente reservados às situações formais:

"Ignatius, honey, the man wants over a thousand dollars for what I did to his building."

"A thousand dollars? He will not get a cent. We shall have him prosecute immediately. Contact our attorneys, Mother."

"Our attorneys? He is got a estimate from a contractor. Mr. Mancuso here says they's nothing I can do."

"Oh. Well, you shall have to pay him then."

"I could take it to court if you think it's best."

"Drunken driving," Ignatius said calmly. You haven't a chance."

Mrs. Reilly looked depressed.

"But Ignatius, a thousand twenty dollars."

"I am certain you can procure some funds," he told her. Is there any more coffee, or have you given the last to this carnival masker?" [Referindo-se ao policial Mancuso.] (ACD, p.53)

$\mathrm{Na}$ insurgência contra o gerente da fábrica Levy Pants, a disparidade entre o léxico empregado por Ignatius e o nível de escolaridade de seus interlocutores é gritante. Esse comportamento demonstra que Ignatius fere também as relações implícitas no conceito de rede social, contrariando a idéia de que "people express solidarity through their use of similar ways of speaking” (Fennell; Bennett, 1991, p.375): 
Ignatius was at last vertically atop the long table, holding the bundled bed sheet over his pelvis to hide from his audience the fact that during the process of being lifted, he had become somewhat stimulated.

"Friends!" Ignatius said grandly and lifted the arm that was not holding the sheet. "At last the day is ours. I hope that you have all remembered to bring your engines of war." From the group around the cutting table there issued neither confirmation nor denial. "I mean the sticks and chains and clubs and so forth." Giggling in chorus, the workers waved some fence posts, broomsticks, bicycle chains, and bricks. "My God! You have really assembled a rather formidable and diffuse armory. The violence of our attack may surpass my expectations. However, the more definitive the blow, the more definitive the results, My cursory inspection of your arms, therefore, confirms my faith in the ultimate success of our crusade today. In our wake, we must leave a sacked and pillaged Levy Pants, we must fight fire with fire."

"What he say?" one worker asked another. (ACD, p. 148)

No personagem de Ignatius a força de convencimento e o humor passam, sem dúvida, pela habilidosa construção lingüística do personagem, o que evidencia a sensibilidade de Toole para tal aspecto da obra literária. Vale ressaltar que as qualidades apontadas podem ser facilmente mantidas na tradução, correndo-se o risco de privar o leitor de boa parte da comicidade de $A$ Confederacy of Dunces caso a rede de elementos que tornam a língua de Ignatius tão bizarra quanto sua presença física e intelectual seja apagada. Mas, se a motriz de Ignatius é mostrar-se “actively offensive whenever possible” (Fennell; Bennett, op. cit., p.377), os diálogos de Mrs. Reilly possuem elementos de outra natureza, assim como é outro o seu temperamento e sua função na narrativa, pois seu desejo é integrar-se à sociedade e garantir para si um final de vida confortável. 


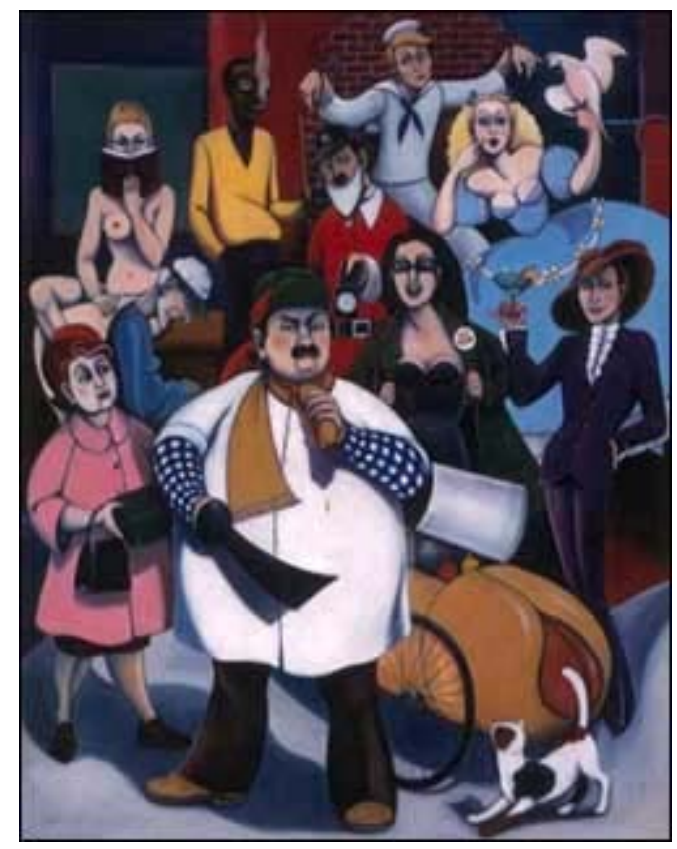

A trupe de A Confederacy of Dunces

\subsubsection{Mrs. Reilly, a anti-sabotagem}

Lê-se na primeira epígrafe de $A$ Confederacy of Dunces:

When a true genius appears in the world,

you may know him by this sign, that the dunces

are all in confederacy against him. (ACD, p. 5)

No caso de Ignatius, a confederação que se organiza contra ele começa em sua própria casa. Mrs. Reilly, que se orgulha de ser "a decent citizen" (ACD, p.211) e traz sempre à tona o tema de seu passado humilde, não se mostra atormentada por dilemas históricos ou filosóficos, mas pela falta de segurança financeira. Tal preocupação está também presente nos personagens que a 
cercam, os mesmos que irão lhe dar força e apoio emocional para que se liberte da tirania do filho. Segundo Daigrepont, Irene Reilly, Santa e Mr. Robichaux

... exemplify the problem evinced in Ignatius' vision of history, namely that of liberation of the lower economic classes, which began as a quest for truth and justice in the era of Renaissance and Reformation has resulted in a widespread, bourgeois quest for economic advancement in which spiritual concerns have often been degraded or cast aside. (Daigrepont, 1982, p.76)

Irene Reilly descende de irlandeses. Já Santa Battaglia beija diariamente o retrato da mãe, cujos "little black coals of Sicilian eyes" (ACD, p 203) não deixam dúvidas quanto ao sangue italiano. Mr. Robichaux, que na gradação dialetal sugerida por Fennell e Bennett encontra-se na metade da escala, não tem a origem explicitada. O próprio Toole parecia estar convencido da realidade de sua criação, como confidenciou em uma das cartas que endereçou ao editor Robert Gottlieb, onde comenta que os personagens do livro são o resultado da observação e da experiência, referindo-se a eles como se fossem de carne e osso:

Irene, Reilly, Mancuso - these people say something about New Orleans. They're real as individuals and also as representative of a group. One night recently I watched again as Santa bumped around while Irene sat on a couch guffawing into a drink. And how many times have I seen Santa kissing her mother's picture. (Nevil; Hardy, 2001, p.139)

As marcas dialetais apresentadas nos três personagens não diferem muito entre si, e alguns marcadores se repetem também na fala de Burma Jones. Essa repetição acontece, por exemplo, com os modais, que estão registrados como oughta [ought], musta [must], shoulda [should], mighta [might], e na dupla negativa em "he ain’t wearing no earring" de Irene Reilly e "I ain gonna rape nobody" de Jones, para citar apenas dois exemplos.

O traço mais saliente da fala de Mrs. Reilly e seus amigos é a marcação sutil que Toole faz das variantes dialetais. Ao contrário da fala de Ignatius, pesada e indivisível, os diálogos de Irene Reilly, Santa e Mr. Robichaux são pontuados por desvios fonéticos, morfológicos e sintáticos delicados, a produzir um jogo entre significante e significado que beneficia a ambos. $\mathrm{Na}$ passagem em que Mrs. Reilly será apresentada ao ferroviário aposentado num jantar oferecido por Santa, é possível observar algumas dessas marcas, bem como constatar que, apesar de toda a 
"carolice" das amigas - elas garantem seguir o "Christian way" (ACD, p. 210) - o dinheiro fala mais alto nas tomadas de decisão:

“To tell you the truth, Santa, I don't think I want to meet this old man."

"Well, it's too late now."

"Yeah, but what me and this old man gonna do?" Mrs. Reilly asked apprehensively.

“Aw, relax, Irene. You making me nervous. I'm sorry I axt you over.” Santa pulled Mrs. Reilly's drink down from her lips for a moment. "Now listen to me. You had arthritis very bad. The bowling's helping that out. Right? You was stuck home with that crazy boy every night until Santa come along. Right? Now listen to Santa, precious. You don't wanna end up all alone with that Ignatius on your hands. This old man looks like he's got him a little money. He dresses neat. He knows you from somewhere. He likes you." Santa looked Mrs. Reilly in the eye. "This old man can pay off your debt!"

"Yeah?" Mrs. Reilly hadn't thought of this before. The old man suddenly became a little more attractive. "He's clean?" (ACD, p.208)

Irene Reilly e Santa apresentam muitos marcadores dialetais em comum, sendo o mais evidente entre eles os desvios morfológicos. No diálogo acima, temos exemplos de conjugações não-normativas em "you was stuck home" por "you were stuck home", "you making me" por "you are making me", ausência de preposição em "you was stuck Ø home" e emprego equivocado do artigo definido em "the bowling's helping that out" por "bowling is helping you out". Irene Reilly usa o pronome oblíquo na função de sujeito em "what me and this old man gonna do" por "what this old man and I gonna do?". O emprego constante de formas de tratamento informais e afetivos, como "honey", "babe", “darling", "sugar", permeia a fala de Mrs. Reilly e Santa. Se Ignatius levanta barreiras na comunicação com seus interlocutores com o objetivo de manter-se isolado, os três amigos formam uma comunidade de fala coesa.

Ciente das vantagens financeiras que a relação com Mr. Robichaux pode oferecer, Irene Reilly termina por ceder, e o flerte entre o casal tem início. Agora, também sob a influência do ex-ferroviário, para quem "it pays to be careful" (ACD, p.212), ela é alertada de que o problema com Ignatius é que ele passou tempo demais na escola, pois "they got plenty communiss in them colleges" (ACD, p.214). O uso de them no lugar do pronome demonstrativo "those" é também uma característica da fala de Ignatius. Irene Reilly, Santa e Mr. Robichaux compartilham 
também da desconfiança de que aqueles que se diferenciam deles são comunistas. Esse será o diagnóstico final de Ignatius e a desculpa para interná-lo no manicômio. No diálogo que se segue, alguns desses elementos podem ser observados, bem como os marcadores dialetais da fala de Mr. Robichaux. Os amigos estão outra vez reunidos na casa de Santa e, por um descuido de Irene, o tópico da conversa vira-se para Ignatius:

“Angelo's [referindo-se ao policial Mancuso] got a hard road to travel," Mrs. Reilly said absently. She was thinking of the PEACE TO MEN GOOD WILL sign that Ignatius had tacked to the front of their house after he had come from work. Miss Annie had immediately started an inquisition about that as soon as it had appeared, screaming questions through her shutters. "What you think about somebody wants peace, Mr. Robichaux?"

"That sounds like a communiss to me."

Mrs. Reilly worse fears were realized.

"Who wants peace?" Santa asked.

"Ignatius got a sign up in front the house about peace."

"I mighta known," Santa said angrily. 'First that boy wants a king, now he wants peace. I'm telling you, Irene. For your own good. That boy's gotta be put away."

“He ain't wearing no earring. I ask him and he says, 'I ain’t wearing no earring, momma.'”

"Angelo don't lie."

"Maybe he just got him a small one."

"A earring's a earring to me. Ain't that right, Mr. Robichaux?"

"That's right," Mr. Robichaux answered Santa.

"Santa, honey, that's a sweet little Blessed Virgin you got on top that TV," Mrs. Reilly said to get them off the earring topic.

Everyone looked at he television set next to the refrigerator, and Santa said, "Ain't that nice, though? It's a little Our Lady of the Television. It's got a suction cup base so I don't knock it over when I'm banging around in the kitchen. I bought it by Lenny's."

“Lenny's got everything,” Mrs. Reilly said. “It looks like it's made outta nice plastic, too, don't break." (ACD, pp. 273-4)

Os desvios morfológicos estão novamente presentes em conjugações impróprias. Temos casos de omissão de verbos em "You Ø making me nervous" e construções interrogativas em que o auxiliar é omitido, e o verbo respeita a flexão do tempo presente, "What you $\varnothing$ think about 
somebody wants peace, Mr. Robichaux?" (Irene). Igualmente representativa é a ausência de preposições, como em "I got plenty Ø relatives" (Santa), “You was stuck Ø home” (Santa), "Ignatius got a sign up in front Ø the house" (Irene). Ainda quanto aos aspectos morfológicos, Santa emprega apenas o artigo indefinido, seja a palavra que vem a seguir iniciada por som vocálico ou consonantal, como em "a earring's a earring to me" por "an earring is an earring". No nível da frase, podemos citar "you had arthritis very bad" por "you had arthritis very badly" ou " you had a very bad arthritis".

Uma das qualidades da fala desses personagens reside na representação das alterações fonéticas que, embora não apareçam em grande número, registram o sotaque dos três amigos. A baixa incidência de estereótipos fonéticos parece ser a fórmula encontrada por Toole para divertir o leitor sem cansá-lo e ao mesmo tempo não ridicularizar os personagens. Da tentativa de recriar a fala desses filhos de imigrantes, encontramos arthuritis por arthritis (Irene Reilly), granchirrem por grandchildren (Santa e Mr. Robichaux), chirren por children (Irene Reilly), potatis salad por potato salad (Santa), ersters por oysters (Santa), axt por asked (Santa), whist por which (Irene), arress por arrest (Mr. Robichaux), communiss por communist (Irene Reilly, Santa e Mr. Robichaux), letrit range por eletric range (Mr. Robichaux), zink por sink (Santa), letrit socket por “eletric socket” (Santa), buncha communiss por bunch of communists (Irene Reilly).

A contribuição mais geral das características apontadas acima reside na diferenciação da fala de Irene Reilly, Santa e Mr. Robichaux em relação aos outros personagens. Mas a recriação literária do falar dos brancos imigrantes é bem menos intensa se comparada ao material de Ignatius e Burma Jones, o que pode sugerir que o autor também marcou na linguagem o nível de integração dos personagens na sociedade ficcional de A Confederacy of Dunces. Mrs. Reilly conquista nossa empatia não apenas em sua sofredora figura maternal, mas no falar sutilmente marcado, que gera certa ambigüidade na reação do leitor, situado entre a piedade e a pilhéria.

Em Burma Jones chegamos ao extremo oposto de Ignatius na escala dialetal sugerida por Fennell e Bennett, quando o inglês não-padrão está congestionado de marcadores, num máximo de saturação dialetal, formando uma unidade compacta de desvios fonéticos, morfológicos e gramaticais. No negro faxineiro, a linguagem por vezes impenetrável esconde o personagem mais lúcido do romance. Desse modo, o plano de Burma Jones de sabotar a patroa racista é bemsucedido tanto no nível do enredo quanto no da linguagem, pois como ele próprio avisa, "If I 
gonna be a doorman, I gonna be the mos sabotagian doorman ever guarded a plantation" (ACD, p. 253).

\subsubsection{Burma Jones, o duplo sabotador}

Burma Jones diferencia-se dos outros personagens integrantes de A Confederacy of Dunces não apenas por seu modo de falar, mas pela consciência que possui de si mesmo e do lugar que ocupa na sociedade na qual o livro se articula. Jones é "the only character in the novel truly to understand and effectively expose the corruption around him" (Macthekan, 1994, pp.37-38). Nesse sentido, a linguagem obscura de Jones é diretamente proporcional à clareza de seu discurso:

Burma Jones speaks clearly to the issue of southern discrimination, his black dialect cuts through all of the others character's foggy pretensions, especially those of Ignatius. (Ibidem, p.38)

O personagem é apresentado ao leitor logo no primeiro capítulo, mas seus diálogos não ultrapassam cinqüenta páginas de um total de quatrocentas do romance. Apesar da pouca presença na narrativa, suas ações são fundamentais para o desenvolvimento do enredo, cabendo a ele a responsabilidade pela "limpeza" da cidade, resultado da remoção de Ignatius e da prisão de Lana Lee. Em sentido mais amplo, Burma Jones é visto como um instrutor na

... complex morality of the city, that is, in the dark heart of humankind. As part of this process of instruction, the black characters help their creators to identify the sin of racism within the sin of pride, illustrating in particular how southern white racism is a function of pride or fear or ignorance, often a perilous combination of all three. (Ibidem, pp. 29-30)

As falas de Jones que ajudam a "identificar o pecado do racismo" pontuam toda a trajetória do personagem, apresentando-se quase que na totalidade de seus diálogos. A estréia de Jones na narrativa dá-se em uma delegacia, para onde ele fora recolhido sob a acusação do furto de um pacote de parafusos. Nesse diálogo, a idiossincrasia do personagem é lançada ao leitor de maneira vigorosa, como as baforadas de cigarro que Jones, impiedosamente, lança sobre tudo e 
todos. Seu interlocutor é Mr. Robichaux, preso pelo policial Mancuso ao interferir numa discussão entre o policial e Ignatius, na abertura do livro:

In the precinct the old man sat on a bench with the others, mostly shoplifters, who composed the late afternoon haul. He had neatly arranged along his thigh his Social Security card, his membership card in the St. Odo of Cluny Holy Name Society, a Golden Age Club badge, and a slip of paper identifying him as a member of the American Legion. A young black man, eyeless behind spaceage sunglasses, studied the little dossier on the thigh next to his.

"Whoa!" he said, grinning. "Say, you mus belong to everthin."

The old man rearranged his cards meticulously and said nothing.

"How come they draggin in somebody like you?" The sunglasses blew smoke all over the old man's cards. "Them po-lice mus be getting desperate."

"I'm here in violation of my constitutional rights," the old man said with sudden anger.

$(\ldots)$

"Sure." A new cloud floated up. "How come you are here, man?"

"I don't know."

"You don know? Whoa! That crazy. You gotta be here for somethin. Plenty time they pickin up color peoples for nothing, but, mister, you gotta be here for somethin."

"I really don't know," the old man said glumly. "I was just standing in a crowd in front of D. H. Holmes."

"And you lif somebody wallet."

"No, I called a policeman a name."

"Like wha you callin him?

"Communiss."

"Cawmniss! Ooo-woo. If I call a po-lice a cawmniss, my ass be in Angola right now for sure." (ACD, pp. 25-26)

Ao episódio da delegacia, segue-se que Jones é obrigado a arrumar um trabalho regular, pois os casos de vadiagem serão punidos pela lei com o encarceramento. McNeill salienta que "like Ignatius, Jones must find a job and discovers that America is the land of inopportune circumstances, of fortune's downward swing" (McNeill, 1984-1985, p. 44). A oportunidade de trabalho aparece em um anúncio da boate Noite do Prazer, onde há uma vaga de faxineiro. 
Recebido pela dona do estabelecimento, Jones passa por uma entrevista, na qual enfatiza o tipo de serviço destinado aos negros:

"I come about that porter job you got advertise in the paper."

"Yeah?" Lana Lee looked at the sunglasses. "You got any references?"

"A po-lice gimme reference. He tell me I better get my ass gainfully employ," Jones said and shot a jet of smoke out into the empty bar.

"Sorry. No police characters. Not in a business like this. I got an investment to watch."

I ain exactly a character yet, but I can tell they gonna star that vagran no visible means of support stuff on me. They told me." Jones withdrew into the forming cloud. "I thought maybe the Night of Joy like to help somebody become a member of the community, help keep a poor color boy outta of jail. I keep the picket off, give the Night of Joy a good civil right ratin."

"Cut out the crap."

"Hey! Whoa!"

"You got any experience as a porter?"

"Wha? Sweepin and moppin and all that nigger shit?"

"Watch your mouth boy. I got a clean business."

"Hell, anybody do that, especially color peoples." (ACD, p.44)

Depois de conseguir o emprego, Jones avalia sua nova condição, concluindo que, aos negros, integrar-se à comunidade pode ser pior do que a exclusão. Lana Lee, mesmo ciente da situação desfavorável do faxineiro, admitido por um "discount price" (ACD, 119), não perde a oportunidade de humilhá-lo:

The broom bumped against the bar several more times. Then, the cloud of smoke and the broom moved off across the floor.

"You oughta tell your customer use they ashtray, tell them peoples you workin a man in here below the minimal wage. Maybe they be a little considerate."

"You better be glad I'm giving you a chance, boy," Lana Lee said. "There's plenty colored boys looking for work these days."

"Yeah, and they's plenty color boy turning vagran, too, when they see what kinda wage peoples offerin. Sometime I think if you color, it better to be a vagran.” (ACD, p.82) 
Ao anunciar o show da dançarina "Harla O'Horror" aos transeuntes da rua Bourbon, Burma Jones satiriza as condições de trabalho a que está submetido, ironizando sua própria condição:

"Hey! All you people draggin along here. Stop and come stick your ass on a Night of Joy stool," he started again. "Night of Joy got genuine colors peoples working below the minimal wage. Whoa! Guarantee plantation atmosphere, got cotton growin right on the stage right in front your eyeball, got a civil worker getting his ass beat up between show. Hey!” (ACD, p. 339.)

Cansado da exploração de Lana Lee, Burma começa a tramar sua vingança contra a patroa. Ao ouvir sobre Ignatius e a tentativa de revolução na fábrica Levy Pants, o faxineiro acredita ter encontrado a pessoa ideal para detonar a sabotagem contra a patroa:

"Shit. I like to fin out where that fat freak hidin out. Maybe I call up Levy Pant and ax for him. I like to drop him in the Night of Joy like a nucular bum. Seem him the kin make that Lee mother shit in her drawer. Whoa! If I gonna be a doorman, I gonna be the mos sabotagin doorman ever guarded a plantation. Ooo-wee. The cotton fiel be burn to the ground before I'm through." (ACD, p.253)

Com a bem-sucedida execução do plano de vingança, Jones está desempregado de novo e mostra-se pessimista. Em seu último diálogo, após a prisão de Lana Lee e o fechamento da boate, a situação de Jones volta a se complicar. Na análise de Daigrepont, "even Burma Jones, who has the vision and courage to fight racial discrimination, sometimes seems less concerned with human dignity than with the material attractions of decent employment” (Daigrepont, 1982, p. 79). Nas palavras de Jones:

Maybe some peoples gettin ahead. Some other peoples be turnin vagran again. Some peoples ain gonna be gainfully employ below the minimal wage after tonight. Some peoples be draggin they ass all aroun town somewheres, be buyin me air condition, color TV.' Shit. Firs I'm a glorify broom expert, now I'm vagran. (ACD, p.362) 


\subsubsection{A linguagem de Burma Jones no nível formal}

As intervenções de Burma Jones são pautadas pelo discurso contra a discriminação racial tanto no conteúdo quanto na forma, o que lhes agrega valor. Toole fez uso dos mais variados recursos estilísticos para compor o $\mathrm{BEV}$ idiossincrático falado pelos personagens negros do romance, a começar pelo cuidado com o ritmo das frases, constituídas, em grande parte, por palavras curtas. Rickford e Rickford observam que

in Black speech, cadence is as crucial to meaning as the words themselves. The rhythm, inflection and rhetorical style are all part of the makeup of the message; the clues that the speaker provides as to his or her mood and the nature of his or her relationship with the audience. (Rickford; Rickford, 2000, p. 4)

De fato, Toole se fundamenta em recursos estilísticos no nível fônico para compor o falar do negro, conferindo ritmo aos enunciados, em especial, graças às supressões e aglutinações de vocábulos. Os diversos marcadores fonéticos empregados por Toole passam pela supressão de fonemas iniciais ou finais, alterações no interior do vocábulo e aglutinações. A apócope é o recurso mais encontrado, principalmente nos vocábulos terminados em $[\mathrm{t}]$, $[\mathrm{g}]$ e [d]. Alguns exemplos são mus [must], wha [what], bes [best], mos [most], lif [lift]; didn [didn't], las [t], don [don't], convic [convict], firs rate [first]; jus [just]; resis [resist]; everthin, draggin, gettin, somethin, callin, sweepin and moppin, payin, becomin, growin, openin, goin, hidin, turnin, standin, grabbin, ratin mutherfuckin; hustlin; runnin; cleanin; waxin; wron; clothin, rollin, learnin; fin [find], fiel [field]; erran [errand], recor plain [record playing], worl [world]; awar [award]. Apesar da grande incidência da eliminação dos fonemas acima citados, encontramos algumas exceções, como what e that, grafados com o /t/ final e screaming, washing, sending, thing, em que fica mantido o /g/. Os vocábulos poor, floor e floors aparecem como po (poor), flo (floor) e flos (floors). No interior da palavra, tem-se a supressão de uma sílaba em probly [probably], reglar [regular] e a inversão em modren (modern), e westren [western]. Quanto aos casos de aférese, encontramos apenas um exemplo, em cause [because]. As elisões estão presentes na fala de Burma Jones bem como nas de Irene, Santa e Mr. Robichaux. As de maior incidência são gotta [got to], gonna [going to], kinda [ kind of], oughta [ought to], gimma [give to], musta [must to], wanna [want to]; sorta [sort of]; lotta [lots of], shoulda [should have]; havta [have to]; lemme [let me]. 
Alguns vocábulos, que receberam um tratamento especial, tendo sido deformados exageradamente, enquadram-se no recurso do "eye-dialect" sugerido por Ives (1950). Como veremos no capítulo seguinte, esse tipo de deformidade gráfica, visando a recompor o modo de falar de personagens de baixa escolaridade, é um elemento usado freqüentemente pelos escritores como reforço na construção do humor. Burma Jones e alguns outros personagens negros menores empregam palavra como cawmniss [communist], grammaw [grandmother], humanitaria [humanitarian], ax (ask), nucular bum [nuclear bomb], awar [war], hisself [himself], mutherfuckin [motherfucker], impressia [impression], yawng [young], oldtimey [old time], tawlet [toalet], chariddy [charity], aigs [eggs], atom bum [atomic bomb], one-hunner-percen [one hundred per cent], whaddya know [what do you know], attagg [attack], sigsty [sixty], grossries [groceries], specia price [special price], ack [act], siphlus [syphilis], coupla [couple], daid [dead], sabotagin [saboteur], cain [can] e barroom [saloon].

No nível morfossintático destacam-se alguns plurais não-padrão ou de uso informal, respectivamente em anyways e somewheres. Há igualmente o emprego do pronome them em vez de those: "them po-lice mus be getting desperate", "tell them peoples, them po-lice take one look at me", "I aint got them cashews, I wonder who lif them nuts" e "where you keep them mutherfuckin broom?” De acordo com Rickford e Rickford, trata-se de aspectos da pronúncia crioula, incluindo o "the use of dem for "those" (Ibidem, p. 17); o mesmo recurso foi observado na fala de Mr. Robichaux, como citado anteriormente. Ainda quanto aos pronomes, há impropriedade de uso em "you oughta tell your customer use they ashtray", "they's plenty color boy turning vagran", "Some peoples be draggin they ass all round town somewheres", "Me, they probly gimma”. Outra característica da fala de Burma Jones é a omissão de preposições: “ plenty $\varnothing$ time", "What kinda Ø change you got", "when they see what kinda $\varnothing$ wage peoples offerin", "anything $\varnothing$ keep my ass away from police", "I got me some peoples $\varnothing$ form a human chain in front $\varnothing$ your door" e "get somebody else $\varnothing$ run your erran”. Omissão do artigo indefinido: “Just $\varnothing$ nigger".

Quanto aos verbos, os exemplos de conjugações não-padrão são abundantes. A omissão dos modais é regra na fala de Jones: "if I call a po-lice cawmniss, my ass $\varnothing$ be in Angola right now", "he $\varnothing$ say", “and I $\varnothing$ say”, “'Hey!' and he $\varnothing$ say”, “ I $\varnothing$ like to fin out”, "I $\varnothing$ like to drop him in the Night of Joy", "some peoples $\varnothing$ be draggin they ass all aroun town somewheres", “ $\varnothing$ be 
buyin me air condition, color TV", "I thought maybe the Night of Joy $\varnothing$ to help someome", “Some other peoples $\varnothing$ be turnin vagran again", "too bad you two ain met She $\varnothing$ love you" e "if I quit, I $\varnothing$ get report for bein vagran". Há uma exceção, porém, na frase negativa: "If I had me some trainin I wouldn be mopping no old whore floor." Outra omissão constante é a do verbo to be , como em "that $\varnothing$ crazy", "she think cause I $\varnothing$ black", "she $\varnothing$ about to trow", "I $\varnothing$ gainfully employ”, "I Ø really a member", “now I Ø a real nigger", “ that $\varnothing$ fine”. No present perfect, o auxiliar está ausente: "like she $\varnothing$ been stab". Diversos enunciados são igualmente apresentados sem auxiliar, por exemplo, em "what kinda change you $\varnothing$ got", "Where $\varnothing$ you keep them mutherfuckin broom?”, "Where Ø I miss a spot?” No tempo presente, ocorre a omissão da flexão na terceira pessoa do singular em "she think I Ø black", "sometime I think if you color, it $\varnothing$ better to be a vagran", "she think $\varnothing$ cause I $\varnothing$ color", "she $\varnothing$ force to be a B-drinker", "He $\varnothing$ a schoolteacher now". No tempo futuro, não há o registro do auxiliar: "maybe they $\emptyset$ be a little considerate", “maybe I $\varnothing$ call up Levy Pant", "they $\varnothing$ probly let you go", "the cotton fiel $\varnothing$ be burn to the ground before I'm through", "some peoples $\varnothing$ be draggin they ass all round town somewheres" e"they $\varnothing$ probly try to prove I got them nuts". No presente contínuo também estão omitidos os auxiliares, recurso verificado em "maybe some peoples $\varnothing$ gettin ahead, "the glasses $\varnothing$ stayin on, "I $\varnothing$ getting pretty tired of bein vagran" e "I $\varnothing$ waitin till I can ring up". Há tempos verbais em desacordo com a gramática normativa: "I come about the job", "I better get my ass gainfully employ", "I never go to school more than two years". Encontrei, ainda, um caso de "regularização" de um verbo irregular: "get your ass throwed in jail".

Todos os marcadores dialetais empregados por Toole na recriação do BEV de Burma Jones e de outros personagens negros do romance apontados até o momento parecem colaborar para a construção de enunciados sustentados por vocábulos curtos e de orações com menos palavras do que rege o inglês padrão. Tal característica corrobora a linguagem cadenciada da fala do negro, sugerida por Rickford e Rickford, conferindo rapidez aos enunciados.

$\mathrm{Na}$ sintaxe, a dupla negativa é uma constante na fala dos personagens negros. Alguns exemplos são: "I ain gonna rape nobody", "I ain walkin in no precinc and flappin my mouth at no 
po-lice", "Color peoples cain fin no job", "I didn call nobody a cawmniss", "I ain cleanin after no animal" e "Don't get yourself in no trouble". Para enfatizar a sagacidade de Burma Jones, seus enunciados apresentam rupturas no esquema sintático em desenvolvimento, numa mudança brusca de assunto. Tal aspecto aparece em "Like this afternoon I standin around in Woolsworth and some cat steal a bag of cashew nuts out the "Nut House" start screaming like she been stab" (ACD, p.26).

Entre os diversos efeitos estilísticos que reforçam o tom coloquial da fala de Burma Jones, gostaria de salientar dois. O emprego generalizado do verbo "get" e de vocábulos obscenos. Do primeiro caso, cito apenas algumas ocorrências, uma vez que essa característica está presente também na fala de Irene, Santa e Mr. Robichaux:

Night of Joy got genuine colors peoples working below the minimal wage. Whoa! Guarantee plantation atmosphere, got cotton growin right on the stage right in front your eyeball, got a civil worker getting his ass beat up between show. Night of Joy got genuine colors peoples working below the minimal wage. (ACD, p. 339)

O linguajar obsceno, por sua vez, é parte integrante do falar de Burma Jones e "caracteriza normalmente a linguagem de grupos de pessoas de menos cultura e posição social” (Urbano, 2000, p. 127). O vocábulo "ass" é o preferido de Jones, que o combina em diversas expressões: "stick your ass", "getting his ass beat up", "trow my ass in jail", "draggin they ass all round town", "gettin their ass blown up", "I better get my ass gainfully employ", "keep my ass away from police", "busting his ass for twenty dollars", "get your ass throwed in jail" e "gettin their ass blowed up".

Este capítulo buscou elucidar aspectos do romance $A$ Confederacy of Dunces e assegurar a relevância de um tratamento diferenciado, na tradução, da fala dos personagens. O projeto de Toole, apresentar uma gradação dialetal entre os diversos actantes, é central para o entendimento da obra, e oferece material profícuo para a interface entre lingüística e literatura. Vimos que Toole manipulou diversos mecanismos sociolingüísticos na elaboração da fala dos personagens, obtendo como produto imediato o humor. 


\title{
CAPÍTULO II
}

\section{DIALETO LITERÁRIO: FORMA E EFEITO}

\author{
Mas, na literatura de uma terra de imigrantes, é de se \\ esperar que haja personagens em cuja voz ressoe um \\ sotaque delator de outros sons e ritmos, que \\ aprendemos, como leitores, a ouvir com os olhos. \\ (Milton M. Azevedo)
}

Procedo neste capítulo à discussão acerca do dialeto literário, suas especificidades e aplicações formais, bem como das funções humorística, identificadora e ideológica que tal recurso assume no texto literário. Ilustro essa reflexão com exemplos de diálogos romanescos pertencentes a personagens negros de textos originais da literatura brasileira. Pretendo igualmente demonstrar como a aplicação de conceitos sociolingüísticos na análise dos dialetos literários migrou das abordagens de enfoque lingüístico para as de teor literário, cuja ênfase recai na narrativa e em suas necessidades intrínsecas e específicas. Tal deslocamento é relevante para os estudos da tradução ao oferecer um alívio teórico à busca de equivalência dialetal entre texto original e texto traduzido, pois, ao sugerir o resgate de sentidos socioeconômicos, culturais, geográficos, entre outros, que porventura integrem a narrativa, sinaliza para um caminho de reconstrução dos dialetos literários cujos limites de funcionalidade estão delimitados pelo próprio texto.

O dialeto literário é um artifício narrativo cada vez mais empregado por escritores contemporâneos, bem como é cada vez maior o número de estudiosos que se dedicam à sua análise (Nomura, 2002, p. 11). As abordagens que apresentarei ora assemelham-se, ora trilham caminhos opostos, oscilando entre uma análise literária que emprega conceitos da sociolingüística para comparar literatura e realidade e outra que busca na sociolingüística conceitos para melhor entender a obra literária. 
No Brasil, grande parte dos estudos sobre a oralidade na literatura deve-se ao pioneirismo de Dino Preti, que, desde seus primeiros trabalhos, aplica estudos sociolingüísticos à análise dos diálogos literários. Em estudo recente (2004), o autor acresceu conceitos da Lingüística Interacional à análise do diálogo literário, sugerindo os níveis macro (variedades lingüísticas) e micro (situação de interação). Outro estudioso do tema é o professor brasileiro da Universidade da Califórnia, Milton Azevedo (2002), cujas análises oferecem uma abordagem estilística de como os escritores, em diversos períodos literários, recriaram as variantes lingüísticas.

Dos EUA, onde a tradição dos estudos sociolingüísticos e do dialeto literário é anterior à do Brasil, recorro ao trabalho basilar de Sumner Ives (1950), de teor sociolingüístico e ainda hoje leitura obrigatória para quem se dedica ao tema. Outra colaboração norte-americana vem da professora da Western Michigan University, Lisa Cohen Minnick (2004), cuja obra não apenas demonstra o método empregado por ela na análise dos dialetos literários, uma mescla de abordagem lingüística e artística - "the best practitioners of literary dialect create effects that are linguistically and artistically believable" (Ibidem, p.33) -, mas constitui fonte de informações históricas sobre o emprego do dialeto literário na tradição literária norte-americana, em especial sobre a representação da fala do negro. A autora apresenta ainda correntes diversas de análise do dialeto literário, das quais destaco aquelas que priorizam a função artística das representações da fala dialetal na narrativa de ficção.

A pesquisadora e tradutora canadense Gillian Lane-Mercier (1990, 1997), por sua vez, debate o diálogo romanesco e o socioleto literário com base na Semiótica, ao entender o primeiro como signo textual construído em função das exigências da instituição literária, fato que, no entanto, não o desvencilha por completo de representar os estratos sociais da realidade extratextual.

\subsection{A construção do dialeto literário}

A Sociolingüística demonstrou como a língua sofre a influência de diversos fatores exteriores a ela, disso resultando grande número de variedades lingüísticas. As variedades diacrônicas são causadas pelo efeito do tempo, as variedades geográficas ou diatópicas, pelo espaço. Inseridas nessas duas dimensões, as variedades socioculturais, ou diastráticas, revelam a posição do falante na hierarquia sociocultural, ao passo que sua forma de realização na língua 
resulta em diferentes modalidades. Sendo as fronteiras entre elas imprecisas, é possível admitir as variedades socioculturais culta e popular, e as variedades situacionais formal e informal; quanto às modalidades, manifestamo-nos no dia-a-dia normalmente por meio da fala (língua falada) e mais raramente por meio da escrita (língua escrita).

Dos ensinamentos da Sociolingüística aprendemos que a variedade formal manifesta em sua modalidade escrita é o que chamamos de norma culta da língua e a que rege, em geral, a língua literária. No entanto, fica claro também que essa combinação é uma entre muitas outras existentes, e não representa a variação à qual recorremos com mais freqüência, a língua falada informal, carregada de elementos regionais e socioculturais, estes caracterizados pelas "linguagens profissionais, étnicas, etárias, grupais etc" (Urbano, 2000, p. 73). A inserção da fala não-padrão na literatura é, portanto, a manifestação do dialeto literário, sob cujo escopo estão alojadas todas as variantes não-padrão de uma língua. Nas palavras de Azevedo:

O conceito de dialeto literário como artifício representativo afigura-se suficientemente flexível para analisar qualquer forma de linguagem de ficção que, escapando aos parâmetros homogêneos da linguagem normativa, vise a representar a oralidade com verossimilhança. Formalmente, é uma técnica baseada na suspensão deliberada e sistemática de regras da escrita normativa, com o fim de refletir características essenciais de cada fala retratada. (Azevedo, 2003, p. 135)

Na definição de Azevedo, os dialetos literários mantêm íntima relação com a fala real, uma vez que buscam "representar a oralidade com verossimilhança", e, para tanto, atualizam no texto literário as "características essenciais" da variante em questão; a abordagem do autor, portanto, valoriza o efeito de mimese na construção do diálogo dialetal, que é apresentado em sua relação com as descrições da sociolingüística acerca das variantes da língua. A concepção "realista" dos dialetos literários remonta aos estudos do norte-americano Sumner Ives, cuja orientação marcadamente sociolingüística caracteriza o termo dialeto literário como "an author's attempt to represent in writing a speech that is restricted regionally, socially, or both" (Ives, 1950, p.137). Ives lançou as bases para se estabelecer o grau de exatidão com o qual as variedades regionais e/ou sociais do inglês norte-americano foram retratadas na obra de ficção, ao propor a consulta aos Atlas regionais lingüísticos, elaborados nos EUA da primeira década do século XX, e concentrar a análise principalmente nos marcadores fonológicos, fato que lhe rendeu críticas entre os pesquisadores da área (Minnick, 2004, p.31). 
De acordo com Ives, os dialetos literários resultam da impressão individual do autor em relação aos falares reais e explicitam os elementos que destoam da maneira de falar do próprio autor e de sua noção do que seja a língua-padrão. Para evidenciar a diferença, os personagens apresentam uma linguagem com marcadores não-convencionais de pronúncia, gramática e vocabulário, que chegam ao texto após uma triagem do escritor. As escolhas do autor são determinadas pelas posições socioeconômica e geográfica às quais ele pertence, ou seja, por meio de qual variante lingüística o próprio escritor se comunica.

O dialeto padrão ao qual nos referimos é, de fato, o dialeto praticado pelo autor (Ives, 1950, p. 150), e contra o qual comparamos os outros falares, o Outro cultural. A voz do narrador sempre foi a referência contra a qual se comparou a fala dos personagens dialetais, o que pode dizer algo sobre as escolhas do próprio autor. Da mesma forma que o escritor domina a língua padrão, em geral os narradores também o fazem. Assim, o sopro de vida dos dialetos literários está no contraste entre as variedades lingüísticas presentes na obra, característica que remete ao conceito de realce (foregrounding), originário do Círculo Lingüístico de Praga, e assinala 'um desvio literário significativo, contra o pano de fundo de uma norma não literária” (Leech, 1992, p. 259 apud Azevedo, 2003, p. 62).

Como veremos adiante, hoje os "falantes dialetais" já ocupam a posição de narradores. Contudo, mesmo nesses casos, a construção dos dialetos literários exige do autor a seleção de características fonéticas e sintáticas da variante que ele irá atualizar. Ives aposta na idéia de que o processo de escolha obedece menos a um método sistemático do que à liberdade artística do escritor:

Nearly all examples of literary dialect are deliberately incomplete; the author is an artist, not a linguist or a sociologist, and his purpose is literary rather than scientific. In working out his compromise between art and linguistics, each author has made his own decision as to how many of the peculiarities in his character's speech he can profitably represent (Yves, 1950, p. 138).

Ives compara o resultado da aplicação do dialeto literário numa obra de ficção a uma “colcha de retalhos", onde os aspectos dialetais "rentáveis" são colocados lado a lado para criar o padrão dialetal ficcional. Nessa construção, o autor privilegiará os hábitos de fala mais salientes do grupo social representado, generalizando-os ao longo do texto. O dialeto literário 
conterá marcadores que serão apresentados de forma mais regular e sistematizada do que no dialeto real, contrariando a observação de que num dialeto real "it is the combination [of speech habits] which is unique rather than the discrete features themselves" (Ibidem, p.152).

O caráter restritivo da construção dos dialetos literários é igualmente observado por LaneMercier em relação à elaboração do diálogo romanesco. A autora aponta para a natureza contraditória da construção do discurso dos personagens, pois a fala ficcional consolida-se na repetição de certos elementos selecionados pelo autor - as "redes de redundância" - os quais, transpostos para o papel, ficam empobrecidos em relação aos diálogos reais devido a um efeito de "clausura". Tal efeito se verifica por ocorrerem, no diálogo dialetal ficcional, perdas de materiais lingüísticos sonoros, verbais e suprassegmentais - acento, duração, altura e entonação e também de marcadores paralingüísticos ou visuais - gestos, expressões faciais ou atitudes corporais:

...tout dialogue romanesque ne contient qu'um nombre plus ou moins limité de particularités pragmatico-linguistiques caractéristiques du parler réel représenté, et ce en raison d'un tri tout à fait conscient effectué par l'auteur parmi ces dermières. Soulignons que ce tri peut opérer à de multiples niveaux et, dans tout les cas, donne lieu à des réaménagements divers qui <réduisent> le taux de réalisme des passages dialogués. Il en résulte ce que nous appelons um effet de clôture, dans la mesure où les réseaux dialogaux intratextuels se trouvent réduits, incomplets, appauvris relativement au modèle réel senti comme nettement plus riche et <ouvert>. De plus, les traits pragmatico-linguistiques effectivement retenus par l'auteur ont tendance à se systématiser au sein du texte et, ce faisant, à engendrer des réseaux de redondances... (Lane-Mercier, 1990, p.61).

A autora trabalha com o conceito de socioleto literário, referindo-se às marcas que caracterizam "the textual representation of 'non-standard' speech patterns that manifest both the social-cultural forces which have shaped the speaker's linguistic competence and the various socio-cultural groups to which the speaker belongs or has belonged" (Lane-Mercier, 1997, p. 45). Nesse caso, as redes de redundância são a cristalização dos aspectos fonéticos ou gramaticais que apontam para a posição sociocultural do personagem, selecionados pelo autor para representar um determinado estrato social. Assim como Ives, a autora observa que os socioletos literários no discurso direto dos personagens apresentam configurações fonética, sintática, lexical e/ou semântica quase sempre arranjadas de forma a mostrá-los negativa ou depreciativamente em relação ao "socially 'neutral", , linguistically 'correct' discourse of the narrator"(Ibidem, p. 46). 
De acordo com a autora, os socioletos literários são "highly stereotypical, based on commonly shared, easily recognizable assumptions of socio-cultural and linguistic differences" (Ibidem, p.46), o que facilita a sensibilização do leitor. Ao manipular as unidades sociolingüísticas extratextuais visando à prática retórica de mimese, o autor produz uma forte carga de sentido estético, ideológico e político. Isto significa que a adequação do fenômeno de fala "real" ao projeto estético do escritor não é uma questão somente de diferença lingüística, mas de representação dos conflitos de poder entre as classes sociais:

Far from constituting a neutral operation, both the stylization process to which literary sociolects are exposed and the comic, picturesque or realistic effects they generate involve the manipulation of real-world class determinations, ethic and gender images, power structure, relations of hierarchy and exclusion, cultural stereotypes and institutional roles. (Ibidem, p.46)

A autora apresenta três resultados possíveis para a aplicação do socioleto literário: o cômico, o pitoresco e o realista, que são determinados pelo nível de saturação das redes de redundância na fala do personagem dialetal. Ives admite que quanto mais marcadores considerados "socially disaproved, old-fashioned or local pronunciations" (Ives, 1950, p.147) estiverem presentes no texto, mais o personagem será caracterizado como "grotesque, humorous, or socially inferior" (Ibidem, p.146). Sobre a intensidade dos marcadores, Pym emprega os conceitos de paródia e autenticidade para caracterizar a intensidade com a qual os desvios aparecem na representação dialetal, em relação à norma estabelecida num determinado produto cultural e não apenas em relação às observações sociolingüísticas. Se forem “only reduced and extreme markers of a truer variety" (Pym, 2000, p.2), salpicados ao longo do texto, como sugerem Ives e Lane-Mercier, trata-se de paródia; aparecendo em quantidade maior, "of finely nuanced accented features, local lexis and faintly non-standard syntax" (Ibidem, p.2), e gerando certa dificuldade de compreensão, aproximam-se do que se consideraria "real" e "autêntico". No primeiro caso, escritor e leitor unem-se para desqualificar o personagem; no segundo caso, emissor e receptor valorizam-no:

Authenticity, like parody, is created in the rapid shift away from an established norm, specifically the norm set up in the course and rhythm of the particular cultural product in 
question. We are dealing with syntagmatic shifts, not just true or false representations.

(Ibidem, p.2)

A representação estereotipada, mais próxima da paródia, é a que tem consolidado a tradição ficcional no que se refere a determinados grupos sociais, "como no caso da 'fala de negros' ou da fala caipira - que habitua os leitores e cria certas expectativas, que funcionam como um ponto de referência obrigatório" (Azevedo, 2003, p. 137). Tal efeito é sentido tanto no nível da tradição literária quanto no âmbito de uma única obra. Em língua portuguesa, por exemplo, um dos marcadores fonéticos mais empregados para remeter à fala do negro é a troca da consoante lateral palatal /lh/ pela semivogal palatal /y/ ou /i/. Podemos citar tal recurso em obras de Gil Vicente (Vicente apud Azevedo, p.70), "Bosso oyo he tam trabessa"; em Machado de Assis (Assis apud Azevedo, p. 70), Eu vaio um galo, sim senhô.”; em Mário de Andrade, “Ói, Frorinda, ocê bem sabe que num sô home pra tá tirano a honra de muié” (Andrade apud Lopez, 1997, p. 107). No nível morfológico, alguns marcadores também estão presentes em diversas obras, como a omissão do /s/ nos plurais. Em Gil Vicente (Ibidem , p.70), "Por o quatro dia no maas"; em Afonso Arinos (Arinos apud Azevedo, p.70), "Leza prôs cativo, mio blanco Senhola do Lozaro", “Não é à-toa que nós mulato gosta mêmo de vancê!"; em Ferréz, e "Sobrevivo comendo coisas que ganho, mano, e até reviro os lixo, é mó treta com os cachorro, cê tá ligado?" (Ferréz, 2002, p. 25).

No âmbito de uma única obra, foi possível observar no capítulo anterior como Toole valeuse de determinados efeitos estilísticos fonéticos e gramaticais para elaborar o BEV de Burma Jones. No correr da leitura, acostumamo-nos com tais marcadores, reconhecendo de imediato quem é o enunciador. Na fala dos negros, a mutilação dos vocábulos nas aféreses e apócopes, bem como a ausência de muitos elementos frásicos - verbos auxiliares, preposições e modais fazem parte da rede armada pelo autor para prender o leitor, ao sinalizar os interlocutores "diferenciados", satisfazer e realimentar a expectativa do leitor em relação ao falar ficcional do grupo social em jogo.

Em Burma Jones, como em muitas representações da fala do negro na literatura, os efeitos fonéticos estão em evidência. Ives debruçou-se sobre esse tipo de elaboração ficcional chegando 
ao conceito de dialeto visual, ou "eye-dialect", um dos truques mais usados, por ser muito eficiente, quando se quer conotar personagens de baixa ou nenhuma escolaridade:

A further type of exaggeration comes from the fact that all dialect writers, so far as I know, sometimes use spellings that mean nothing at all phonetically; they are merely a sort of visual sign to the reader that the dialect speaker is not literate. (Ives, 1950, p. 147)

O dialeto visual é a técnica de reescrever uma palavra modificando um ou mais de seus fonemas com o objetivo de que ela sugira o vocábulo-padrão. As deformações podem ser em graus variados, até a desfiguração total. Para tal composição, o autor vale-se da expressividade sonora dos vocábulos por meio dos metaplasmos, sendo os casos de supressão de som nas várias partes dos vocábulos os mais freqüentes. Preti nomeou essa técnica de "ortografia fonética individual" do autor, em alusão à transcrição dos símbolos fonéticos convencionais, e alertou para a ininteligibilidade dos diálogos caso o autor exagere na singularidade da fala do personagem (Preti, 1994, p.65). Ives considera o emprego do dialeto visual como o recurso que mais negativamente caracteriza o personagem, pois está "deliberatly overstanding the ignorance or illiteracy of his characters.” (Ibidem, p.147) Na opinião de Lane-Mercier, os estereótipos fonéticos, alimentados pelas deformações gráficas, também geram “effets supplémentaires de comique et de ridicule"(Lane-Mercier, 1990. p.47).

\subsection{A "língua de preto"}

As colocações acima implicam reconhecer que, até recentemente, os negros foram retratados de forma inferiorizada em nossa literatura, pois desde as primeiras tentativas de ilustrar a diferença sociocultural dos personagens, os autores de língua portuguesa recorreram largamente a uma fonética individual. Azevedo, remetendo-se ao filólogo francês Paul Teyssier ${ }^{4}$, cita a tradição literária da "língua de preto", uma representação literária da fala precária dos escravos negros que começavam a desembarcar em terras portuguesas, em meados do século XIII (Azevedo, 2003, 66). Um dos autores que mais se destacou nessa tradição e popularizou o "exotismo" da fala do negro foi Gil Vicente, levando aos palcos portugueses personagens cômicos que falavam “em seu português xacôco para gáudio dos ouvintes” (Mendonça, 1973, p.

\footnotetext{
${ }^{4}$ TEYSSIER, Paul. La langue de Gil Vicente. Paris, C. Klincksieck, 1959.
} 
58). Em A Influência Africana no Português do Brasil, Mendonça cita "a presença de uma literatura curiosa em que apareciam sonetos, sermões, almanaques e calendários em língua de preto" (Ibidem, p. 58) já no século XV, e destaca um "fenômeno fonético, a substituição do th por y que aparece freqüentemente nessas representações" (Ibidem, p.58). Frágoa de Amor (1524-25?), de Gil Vicente, é conhecida por sua comicidade no trato com o "português africano":

Que inda que negro soo

Bosso oyo he tam trabessa,

Tam preta, que me matoo.

Senhora, quem te frutasse

Por o quatro dia no maas

E logo morte me matesee,

Que mas o dia nam durasse

Pollo vida que boso me das.

(Azevedo, 2003, p. 66)

Além da já citada substituição do /lh/ por /y/, há também outro marcador bastante recorrente na literatura para representar a fala do negro, a troca do fonema $/ \mathrm{v} /$ por $/ \mathrm{b} /$. Temos uma alteração no interior do vocábulo em "frutasse" por "furtasse", além do (não) plural impróprio em "quatro dia". Mendonça aponta as peculiaridades retratadas por Gil Vicente como "alterações fonéticas de origem africana" (Ibidem, p. 61) presentes na fala do brasileiro, resultado da presença do negro, a partir do século XVII, "na intimidade da família, na vida do campo bem como na cidade" (Ibidem, p.60) em substituição ao índio, o que possibilitou a influência dos negros em nossa língua popular.

$\mathrm{Na}$ obra supracitada de Mendonça, o autor faz um levantamento da presença de personagens negros na literatura brasileira e ressalta que o primeiro escritor a retratar o negro no Brasil "não foi Castro Alves e sim um poeta maranhense, Trajano Galvão, que viveu entre $1830 \mathrm{e}$ 1864" (Ibidem, p.100). No entanto, como pude constatar, no poema a Crioula ${ }^{5}$, a voz da narradora não apresenta marcadores de nenhuma ordem. Entre os romancistas nacionais que recorreram largamente ao dialeto visual para a composição lingüística dos personagens destaca-

\footnotetext{
${ }^{5}$ Amadeu Amaral, A Literatura da escravidão, in Revista no Brasil no. 29 - maio de 1918.
} 
se Coelho Neto (1864-1934). Na obra Rei Negro, a fala do escravo destoa da linguagem castiça do narrador e dos outros personagens, reforçando a visão estereotipada do negro:

Na véspera da partida, à tarde, arrumando a maleta, o negro chamou-a:

- Oia, véia, toma bem conta della, não dêxa ella. Ocê fica aqui: sinhô boto Thereza p'ra cuida du chiquêro. Istende istêra na sala i dorme lá.

- Vai dicançado, fio di Deus. Lucia não tem nada de maió. Ocê mêmo é que bot'ella ansim. - Você já vai?-J'é hora.

Abraçaram-se em silêncio. Ella desprendeu-se-lhe dos braços, atirou-se nos travesseiros abafando o choro.

- Não chóra, tôla. Noss'Sinhô ta hi. Ainda a beijou, acaraciou-a: Adeu! Té a vorta.

A lua velava muito alta. $O$ terreiro parecia de cal. Toda a paisagem jazia sob uma nívea furfurina diaphana. Tiniam campainhas no silencio. (Neto, 1926, p.149)

O abolicionista parece ter empregado o dialeto visual na melhor das intenções. Apesar do congestionamento de marcadores, a seleção das características da fala do negro parece ter sido acertada em alguns aspectos. Temos a vocalização costumeira do /lh/ em /i/ (óia, veia, fio), redução dos ditongos "ei” (chiquero, dexa), a metátese em "dicançando"; todas características fonéticas apontadas por Mendonça como resultado da influência africana no português do Brasil. No entanto, o afã "realista" de Coelho Neto sobrecarrega a representação, gerando um contraste negativo em relação à voz do narrador.

A elaboração de uma fonética individual para caracterizar a fala do negro é também encontrada entre autores modernistas. No conto Foi Sonho, Mário de Andrade dá voz a um narrador negro que tenta convencer sua companheira de que a infidelidade dele não passou de um sonho. O monólogo é construído na tradição de representar a fala do negro com estereótipos fonéticos, aplicados ao texto de forma bem carregada:

Será que você qué abandoná seu negro pru causo de otra...

Antão arresorvi vim buscá ocê. Ói, Frorinda, ocê bem sabe que num sô home pra tá tirano a honra de muié...Só tirei a honra de uma, foi você, pruque nóis dois se pirtincia. Mais porém te dei a minha, que ocê é que guarda a honra de seu negro, num é mermo?...diga! E agora, será que ôce tá 
quereno me dishonrá...Antão você vai dá de mostrá pr’us otro que tu é uma disgraçada, quano num é!...

Eu inté não gosto de jurá pruque sô home cumpridô de sua palavra, mais...ói! te juro que nunca mais hei-de oiá pra outra mulé, é ocê que eu quero bem, te juro! Bamo fingi que tudo o que sucedeu, num sucedeu, foi sonho, e hei-de te prová que foi sonho memo, num dexô siná. Bamo cumigo, Frorinda... (Andrade apud Lopez, 1997, pp.107-108)

Nessa representação, Mário de Andrade baseia-se em vários aspectos da fala do negro para elaborar o dialeto ficcional. Destaco a apócope em verbos (abandoná, buscá, dishonrá, mostrá), o rotacismo ( Frorinda por Florinda), a vocalização (muié por mulher)e a redução (otra por outra). Tais singularidades são apontadas por Mendonça como pertencentes à fala popular brasileira. Mais uma vez, a comicidade está associada ao excesso de processos fonológicos. Entretanto, se o nível fônico foi bastante explorado até meados do século passado, os autores mais recentes deslocaram seus marcadores dialetais para as esferas do léxico e da gramática, alterando a tradição da "língua de preto", iniciada há 500 anos, em especial ao introduzirem narradores em língua não-padrão.

O valor do léxico na recriação dialetal é salientado por Preti, para quem "as maiores aproximações [em relação aos dialetos reais] estão sempre no nível lexical” (Preti, 2004, p. 121). Como explica Martins, "a tonalidade emotiva de um grande número de palavras se deve a associações provocadas pela sua origem ou pela variedade lingüística a que pertencem” (Martins, 2000, p. 80). São os estrangeirismos, as palavras indígenas, os arcaísmos, os regionalismos e as gírias. A gíria, por exemplo, é largamente empregada por autores da chamada literatura marginal, produzida por jovens da periferia dos grandes centros urbanos; como corrobora Martins, "no presente século, a gíria passou a ter acolhida na literatura, evocando os meios populares dos grandes centros urbanos" (Ibidem, 89).

Na cidade de São Paulo, há a projeção de um autor do bairro de Capão Redondo, Ferréz, cujos romances Capão Pecado (2000) e Manual Prático do Ódio (2003) são um inventário de gírias dos jovens dessa comunidade e retratam o que é "ser preto, pobre, filho de mãe solteira negra, que veio da Bahia com doze anos de idade" (Brown apud Ferréz, 2000, pp. 23-24). No 
diálogo abaixo, que abre a narrativa de Capão Pecado, os interlocutores parecem disputar quem conta mais infortúnios, com a mais fina ironia:

- Aí, mano! Eu bebo todo dia, cê tá ligado?

- Fumo pra cacete, mano, durmo sempre aqui em frente à vendinha da Maria.-Já vi de tudo aqui no Capão, coisa que até o diabo duvida, mano, cê tá ligado?

- Sobrevivo comendo coisas que ganho, mano, e até reviro os lixo, é mó treta com os cachorro, cê tá ligado?

- Já fui esfaqueado duas vezes, mano; uma pelo Luís Negão e a última foi pelo Sandrinho e o China, uns moleque forgado da porra.

- E agora você pensa: tudo isso eu ainda tô vivo, mano. Agora uma pá de maluco que comia bem pra caralho já foi embora, é só você pensar, o Senna, o Jânio, o João Paulo, o PC Farias, a mãe do Collor, o irmão do Collor, o Leandro, aquele da dupla sertaneja, cê tá ligado? Então num é embaçado, mano? Aí, eu vou sair fora agora, vai ter um boi na brasa lá no Saldanha, e hoje eu vou comer que nem um cachorro, falou Marquinhos, depois a gente se cruza.

- Falou Vasp, depois a gente se tromba. (Ferréz, 2000, p. 25)

É possível observar o emprego constante do marcador conversacional, "cê tá ligado", cuja função não é semântica, mas contribui “para a fluidez da comunicação" (Azevedo, 2003, p.27) e assim aumenta o nível de interação entre os interlocutores. É a transposição de um elemento pertinente na recriação da oralidade na escrita. As gírias permeiam o texto: "pra cacete”, "mano", "mó treta”, “forgado" (por folgado), “pá", “embaçado", "se cruzar”, “se trombar”, "sair fora”. Como explica Preti, a gíria é uma variante sociocultural da língua e surge como resposta de um determinado grupo social à sua exclusão do todo da sociedade:

A gíria, portanto, como mecanismo de agressão e defesa, podemos dizer, ganha um caráter de elemento compensatório, meio de purgação da alma popular. Optando pelas formas gírias, deformando significantes da linguagem usual, criando significados especiais, o falante agride com esse vocabulário o convencional, opõe-se a um comportamento lingüístico, escolhido pela maioria como norma e, assim, deixa marcado seu conflito com a sociedade. (Preti, 1984, p.22.)

A violência urbana como resultado da exclusão social é o tema do segundo romance de Ferréz. O autor mantém o mesmo padrão lingüístico de reconstrução da língua dos jovens pobres 
da periferia de São Paulo, sustentando sua técnica principalmente na escolha do léxico. Ainda que, como visto acima, encontremos algumas alterações fonéticas, como o rotacismo ("forgado" por folgado) e desvios morfossintáticos nas concordâncias de número ("reviro os lixo"), as gírias e os vocábulos de baixo calão sobressaem. No trecho a seguir, os interlocutores tramam a morte de um terceiro sujeito, mas Régis irá trair Nego Duda, que acabará morto:

- E aí, Nego Duda? Porra, nem te vi, tudo pela ordí?

- Mais ou menos, Régis, oh! Tô precisando de uma dica sua, oh, e isso vai me dá mó visão.

- Diga então jão, se puder eu ajudo.

- Vamo pro canto, chega aí. (...)

- O barato é o seguinte, tô com um esquema bom, pra fazer um maluco.

- Quem que é? - perguntou Régis colocando a mão dentro da cintura novamente, com o temor de Nego Duda falar que era ele, se fosse esse o caso, quem puxasse primeiro fritaria o outro.

- Você num conhece, mora longe.

- Sério? - disse Régis tirando a mão da cintura novamente.

- Mas num é isso que interessa, o que pega é o seguinte, o maluco quer dar cinco pau pra o outro ir pro inferno, só que quero saber com você como vou fazer isso?

- Fazendo, porra! - respondeu Régis com ironia.

- Cê tá me zuando, eu sei, mas num sei se pega alguma coisa, o maluco mora lá no Brás, pode ser encrenca, num conheço a área, truta.

- Peraí, deixa eu pensar...Faz assim, ó, dá um psicológico no cara, nesses caso, força num é nada, você tem que usar a sapiência.

- O quê?

- Esquece, vou resumir procê, (...) assim cê num corre risco fazendo merda na área dozotro.

- Mas o maluco não vai pagá adiantado, eu acho.

- Paga sim, fala que é garantido, (...)-de crê, Régis, ó, vou dá dessas memo, e depois ele num vai poder falar com o Valdinei da padaria, afinal difunto não fala, né não? (Ferréz, 2004, pp.33-35)

Novamente, a reconstrução da fala do grupo sociocultural retratado nos romances de Ferréz permite situar os falantes num terreno onde a língua é também um instrumento de luta social. A gíria, nesse sentindo, é bastante expressiva em sua função de marcar na língua o conflito entre as camadas socioculturais. Temos "tudo pela ordí" (em ordem), mó (por maior) visão, "fazê (fazer) um maluco (matar), "pegar” (o que está acontecendo), “jão”, "truta” (amigo), zuar (troçar de 
alguém); observe-se que muitas dessas gírias apresentam também alterações fonéticas. É interessante notar a utilização de gíria também pelo narrador, como em "se fosse esse o caso, quem puxasse primeiro fritaria o outro"(mataria o outro).

No entanto, o gênero que mais se destaca no Brasil por representar a fala dos negros de forma inovadora é o conto atual. A violência urbana (e humana) é o tema de outro escritor contemporâneo, o pernambucano João Filho. Em Encarniçado o contista faz uso de uma linguagem incomum, demonstrando preferência por uma representação estilizada da linguagem oral. O negro Jeromão, protagonista de Finta-de-traço, ex-craque de futebol de segunda divisão e sambista, está assim representado:

Ah... como gozaria meu traço se lograsse alguns elásticos na Língua, fedendo urina, o que for mais que ponto e vírgula, exita. Jeromão, jamanta retinta, putárico daí que sambista, só em caçarola batuca - "invernô, invernô, Gué-Cabeção invernô", valsila não, que desce-o-badego. trovão de voz -“ê-pa-ê poeta, meu traíra predileto" e risava, chapa'num'canto da boca comida por dente sobrado. retintão e hoje jamanta, mas nunca estiva. moleque-picolé-pastel, vendedor. seu velho sanfona'dedilha, hoje enferrujado por janeiros idos.

"um veludo..." quando inquiro Maciel, "sabe Toninho Cerezo? Um cisne ao pegar na bola, mas ao deslocar-se, um pato", asas'gesticula. "força'estampido, arrojo, mas ao pespegar na cilíndrica veludo..."

craque segundona, boleiro por baixo, dois três mínimos, soldo suado. Campeão juvenil quando Aymoré Moreira o Bahia treinava. afoito de menino'ossudo, Dadá Maravilha, malaca, né, atiçou “ vai Jerimum!", assim chamado caí pra dentro, espanquei novato, suspensão cumpri, mamão, né. No Vira-Copos espalmei facão na cintura e fui rela-buchar co'as cabrochas, qual causa?! Biquinha, este por ti ficcionado, ele pensou que'eu ia'abrir e acendi, o salão lotado - arreganhou. Biquinha fez menção de tá berrado. que-nada, pixote.

na Argentina jogara, "espera'aí, na segundona da província”. do castelhano apenas'só "gracias, me gusta"e risava o bigodinho a la'malaca, numa macieza de pé-de-pano, calça branca vincada, camisa comprida, corte rente'gris na carapinha, nariz taboca, tão amálgama que chibarro, como a Língua. (Filho, 2004, pp.109-110)

A prosódia da fala do personagem está marcada no ritmo da oxítona "invernô", bem como em "ê-pa-ê poeta", conferindo certo ritmo malandro à fala de Jeromão. Os apóstrofos aglutinam os sintagmas, incorporando a velocidade da fala espontânea em "co' as", "ele pensou 
que'eu ia'abrir e acendi" e a união de "que-nada". No léxico, temos os neologismos "relabuchar" (dançar) e "tá berrado" (estar armado). O emprego do itálico representa o aumento da entonação, a exaltação do personagem em relatar o fato. No nível da frase, observa-se o emprego de orações assindéticas, cuja contribuição estilística é a de marcar "um tom mais espontâneo, menor rigor lógico; é mais ágil, sugere a simultaneidade ou a rápida seqüência dos fatos" (Martins, 2000, p. 137).

Outro escritor que vem marcando na sintaxe a fala ficcional do negro, em especial no apagamento da virgulação, é Marcelino Freire, cujo conto “Trabalhadores do Brasil” apresento na íntegra:

Enquanto Zumbi trabalha cortando cana na zona da mata pernambucana Olorô-Quê vende carne de segunda a segunda ninguém vive aqui com a bunda preta pra cima tá me ouvindo bem?

Enquanto a gente dança no bico da garrafinha Ode trabalha de segurança pega ladrão que não respeita quem ganha o pão que o Tição amassou honestamente enquanto Obatalá faz serviço pra muita gente que não levanta um saco de cimento tá me ouvindo bem?

Enquanto Olorum trabalha como cobrador de ônibus naquele transe infernal de trânsito Ossonhe sonha com um novo amor pra ganhar 1 passe ou 2 na praça turbulenta do Pelô fazer sexo oral anal seja lá com quem for tá me ouvindo bem?

Enquanto Rainha Quelé limpa fossa de banheiro Sambongo bungo na lama e isso parece que dá grana porque o povo se junta e aplaude Sambongo na merda pulando de cima da ponte tá me ouvindo bem?

Hein seu branco safado?

Ninguém aqui é escravo de ninguém. (Freire, 2005, pp. 19-20)

É possível notar que a prosódia do enunciador é livre de vírgulas, e, nas frases, as orações são alinhavadas por aliterações, que determinam o ritmo dos parágrafos. Há um efeito bastante interessante na duplicação da locução "de segunda categoria" ao unir-se com de "segunda a segunda". O tom ameaçador do narrador não dá vez nem a réplica, nem a qualquer tipo de comicidade.

Remetendo-nos à história literária do Brasil, observamos como as escolhas das marcas dialetais passaram do nível fonético, altamente estereotipado, para marcações no léxico e na 
gramática. Essa transformação foi acompanhada de outra mudança significativa, a de que hoje os narradores também não se expressam na língua-padrão, o que amplia a heterogeneidade lingüística na narrativa literária e afasta o valor negativo dos personagens dialetais.

\subsection{Restrições à representação dialetal}

O problema da construção formal dos dialetos literários não está restrito apenas às escolhas do autor entre as marcas dialetais que figurarão no texto, em seus diversos níveis. Dentre os obstáculos à representação dos dialetos na literatura, e igualmente relacionado ao caráter redutor das representações dialetais no diálogo romanesco, situa-se a limitação dos recursos fornecidos pela ortografia. Como observa Urbano:

Como língua escrita, vê-se ela, pois, a braços com as restrições técnicas que o canal escrito impõe. O escritor tenta, muitas vezes, servir-se dos mesmos recursos gráficos gramaticalmente previstos, dando-lhes, porém, novos usos e funções. Quando são insuficientes, cria outros, para consecução de efeitos estéticos. Ocorre, com efeito, que principalmente o escritor moderno procura transpor para a sua obra, na fala de seus personagens, a pronúncia cotidiana do povo e, para tanto, os recursos normais, tradicionais da língua escrita, geralmente não bastam. (Urbano, 2004, pp. 129-130)

Como vimos, a criatividade dos escritores vem renovando o potencial expressivo de recursos como o itálico, a maiúscula, as reticências, o hífen, entre outros, na busca de transmitir “o ritmo, a entonação e todas as variações - de altura, duração, timbre” (Azevedo, 2003, p. 44),

embora esses recursos costumem "ser subsidiários, e é raro que tenham um papel central" (Ibidem, p.49). Igualmente de difícil representação são os elementos paralingüísticos, como gestos, expressões faciais ou atitudes corporais, que poderão apenas ser explicados pelo narrador ou pelos personagens.

Remetendo-se aos estudos da Análise da Conversação, à Lingüística Interacional e à Teoria da Enunciação, Urbano elenca uma série de contrastes entre escrita e fala, resultado de estados diferentes de produção, recepção e canal, responsáveis por limitar a representação da oralidade na literatura. A espontaneidade da língua falada é analisada no que Urbano considera a diferença central entre a língua falada e a escrita, a "execução única, sem revisão e apagamento possível” da língua falada, resultado da simultaneidade entre o pensamento e a sua expressão, 
diferentemente do que acontece no ato de escrever (Ibidem, p. 88). Outro aspecto salientado é o da interação, pois, no caso da fala, os enunciadores, falantes e ouvintes participam de um mesmo momento de conversação, o que propicia maior envolvimento entre os interlocutores.

Além das restrições do canal escrito, Ives e Preti estão de acordo em relação a outro aspecto delimitador da presença dos dialetos literários nos diálogos romanescos - a tolerância do leitor. Ives afirma que "at some point, the author must restrain his desire to be comprehensive and give some thought to the patience and understanding of his readers" (Ives, 1950, p.148). Trata-se do que Preti chama de "estruturas de expectativa do leitor" (grifo do autor) (Preti, 2003, p. 145), ditadas pela "tradição da linguagem culta", mas igualmente pela repetição de determinados desvios na caracterização dos dialetos geográficos ou sociais. O leitor, em seu conhecimento prévio de mundo, o qual é atualizado no ato de leitura, encontra-se entre os dois pólos, a linguagem culta e a linguagem do personagem, e sua tolerância parece responder a um meio termo entre essas convenções. No entanto, sendo a expectativa do leitor um "gosto" construído, é passível de ser transformada pela ousadia de escritores e editoras.

Lane-Mercier não aceita o argumento da restrição do canal escrito como empecilho à presença de variantes não-padrão na literatura, pois continuamos a trabalhar com signos lingüísticos. Por conta disso, a pesquisadora sustenta que cada vez mais os autores sabem tirar proveito dos elementos do diálogo real para criar interações convincentes nos romances, sendo estes "susceptibles de présenter une homologie privilégiée avec leur $<$ référent $>$ extratextuel, dans la mesure où il s'agit de la tranposition du linguistique (le code oral) par du linguistique (le code écrit), ce que donne lieu à de puissants effets de mimésis” (Lane-Mercier, 1990, p. 44). A autora conclui que a inserção de variantes lingüísticas no texto literário está cada vez mais elaborada e bem-sucedida, sendo possível representar de maneira bastante convincente "une certaine façon de prononcer, des structures syntaxiques ou des champs sémantiques plus ou moins stéréotypés" (Ibidem, p.44), bem como peculiaridades do momento de interação.

Tanto é verdade que, em seu último livro sobre o diálogo literário, Preti sugere dividir a análise em duas instâncias. Primeiro, uma macroanálise, que deve buscar a presença de marcadores que denunciem a posição sociocultural do personagem, o "contexto histórico e geográfico, fatores extralingüísticos e sua possível influência sobre as personagens ou o narrador de primeira pessoa, tais como grau de escolaridade, profissão, posição social, faixa etária, sexo dos falantes" (Preti, 2004, p. 121), perceptíveis graças à aplicação de conceitos da 
sociolingüística; em seguida, proceder a uma microanálise, que repousaria em conceitos da Lingüística Interacional, diz respeito à situação de interação entre os interlocutores e "compreende todos os elementos pragmáticos que acompanham as falas e que geram contrastes como proximidade/afastamento, clareza/ocultação, poder/submissão, etc., além de estratégias conversacionais empregadas pelos interlocutores durante o diálogo" (Ibidem, p.121).

De acordo com Lane-Mercier, os diálogos romanescos rejeitam a presença de uma linguagem outra que não a culta por terem de se conformar às exigências de serem signos textuais literários. Assim, enquanto Ives defende que os dialetos literários são recriados graças a uma lógica de realismo e transparência na inserção da fala no texto, num compromisso com a verdade do dialeto e por meio de efeitos de mimese, a autora entende as réplicas intratextuais como "partie intégrante d'un système sémiotique univoque, contraint de se conformer, entre autres, aux exigences d'um, genre d'une esthétique (réaliste ou non) et d'une logique narrative" (Ibidem, p. 44). Como resultado, o caráter redundante, redutor e freqüentemente episódico dos socioletos romanescos é "déclenchées par le triple travail du scriptural, de la fiction et de l'idéologie du texte" (Ibidem, p.44), e se aloja nas limitações impostas pela instituição literária:

Historiquement marquées vis-à-vis d'une forme perçue comme normative, ces inscriptions se posent em tant qu'infractions et, comme telles, portent atteinte tantôt à l'institution littéraire (qui a toujours prôné la standardisation de l'orthographe ainsi que tout um code de $<$ bienséances verbales $>-$ em témoigne, jusqu'au mouvement naturaliste, l'exclusion des parles populaires et argotiques du domaine littéraire), tantôt au scriptural, senti comme supérieur au code oral parce que plus homogène (voir l-e refus d'enregistrer les < ratés $>$ de la commication: bafouillage, hésitations, < bruits $>$ non linguistiques), tantôt encore à um discours dominant précis. Cela explique, du moins em partie, la forte charge idéologique dont um sociolecte, par définition, se leste et que les représentations intratextuelles ne font que souligner, d'une manière ou d'une autre. (Ibidem, p. 45)

Lane-Mercier esclarece que é para resguardar as "convenções institucionais" e manter "um certo realismo sociolingüístico" que o sistema escrito e literário coloca à disposição do escritor “diferentes procedimentos - anúncios, itálicos, precisões diegéticas, salpicadas discretas, entre outros”. Essas indicações, que separam o narrador das infrações às normas literárias, revelam "um desejo de distanciamento, por si só altamente ideológico" (Ibidem, p. 45), da parte do autor. Em nossa literatura, a presença de um "cordão de isolamento" entre narradores cultos e 
personagens dialetais foi detectada por Azevedo, que afirma a utilização entre os pré-modernistas de

(...) recursos gráficos para interpor certa distância entre a fala popular, cuja marginalidade vem assinalada por aspas e apóstrofos, e o texto em linguagem padrão, atribuível à voz narradora (Azevedo, 2003, p.73).

\subsection{O dialeto literário como signo textual}

Compreender o dialeto literário como um signo textual é uma mudança de paradigma na análise desse artifício. Como sentencia Lane-Mercier, "la parole fictive n'oublie jamais sa littérarité" (Lane-Mercier, 1990 p. 47). A transferência do foco de análise do grau de acuidade com a qual o escritor retratou um dialeto real para o entendimento de que essa reprodução é infiel, pois obedece às exigências do meio em que está representado, cria novos objetivos para as análises dos dialetos ficcionais. Preti, cuja linha de pesquisa se apóia nos conhecimentos da sociolingüística e da lingüística interacional para levantar quais elementos reais estão presentes na ficção, também compartilha da assunção de Lane-Mercier de que a tradição literária cerceia a presença de variantes da língua em seu território e admite que tais "infrações" serão aceitas pelos leitores apenas se possuírem uma finalidade intrínseca ao texto:

O peso da tradição da linguagem culta para o narrador (principalmente, o onisciente, de terceira pessoa) e as variações lingüísticas da linguagem das personagens e do narrador de primeira pessoa sempre estiveram de acordo com certos limites impostos pela tradição cultural. Para o emprego de uma linguagem popular, mais livre, com a aceitação de gírias, modismos populares, quebra de tabus lingǘ́sticos, seria necessário que essa atitude do escritor correspondesse a uma necessidade do texto, a uma verdade artística. (Preti, 2004, p.146)

Chegar à verdade artística de um romance é o propósito pelo qual alguns estudiosos vêm se dedicando à análise dos dialetos literários. No capítulo intitulado "Linguists, Literary Critics, and Literary Dialect”, Minnick apresenta um panorama das várias correntes de análise dos dialetos literários nos EUA e menciona trabalhos de crítica literária que englobam a análise dos diálogos 
dialetais visando a determinar o "sucesso artístico" do texto e não o grau de exatidão sociolingüística da representação dos dialetos.

A autora cita Roger W. Cole, cuja defesa de uma análise das representações da fala humana julgada "in terms of function or purpose of that speech within [a work's] overall artistic scheme: in terms of the artistic work as a whole" (Cole, 1986, p. 4 apud Minnick, 2004, p. 31) não desloca a visão do pesquisador do objeto de estudo, mas oferece a esse mesmo objeto - os dialetos literários - uma outra finalidade. Na opinião de Cole, o dialeto literário funciona não se estiver de acordo com as observações da Sociolingüística sobre as variantes da língua, mas se for artisticamente crível. Sobre a análise do emprego do dialeto literário na obra de William Faulker, analisado por Helmut Esau, Norma Bagnall e Cheryl Wares, Minnick observa que

(...) more important than determining accuracy and mapping the fictional dialect, which they, like other critics, claim is the legacy of early literary dialect analysis theory, is determining the social and linguistic "hierarchy of values" among the characters correlate to the social class structure of the fictional community. (Ibidem, p. 35)

A mesma idéia persiste na análise de A Confederacy of Dunces, apresentada no capítulo anterior, realizada por Fennell e Bennett ao interpretar o protagonista por meio da análise de suas peculiaridades lingüísticas e desvendar a gradação dialetal na qual se baseia a obra. $\mathrm{Na}$ análise que fiz, também observei como a saturação no nível de marcadores dialetais está em proporção direta ao nível de inclusão do personagem na sociedade ficcional do romance. Fennell e Bennett sugerem que a abordagem "artística" dos dialetos literários seja levada também à sala de aula:

(...) students might be encouraged to concentrate not on whether a particular author represent a particular dialect "accurately", but on the literary effect achieved by the actual dialect features used, that is, some aspect of the author's plot or character or group of characters. (Fennell; Bennett, 1991, p. 378)

\section{5 As funções identificadora, ideológica e humorística do dialeto literário}

Se, por um lado, determinar a exatidão com a qual um dialeto foi representado no texto literário não é mais uma obrigação daqueles que agora se debruçam sobre o tema, e a "verdade artística" do emprego dos dialetos literários pode ser estudada em sua interação com outros 
elementos da narrativa, por outro ainda não há como escapar às associações com o real operada pelos dialetos literários. Lane-Mercier acredita que os dialetos literários são "signos motivados", pois carregam em si a função de identificar um grupo social e uma ideologia:

... l'allure stéréotypée [d'un sociolecte] résulte d'un transfert direct d'éléments syntacticosémantiques du code parlé, ceux-ci subissent une systématisation textuelle qui em opère une clôture au deuxième degré - littéraire cette fois - cautionnée par l'émergence de réseaux redondants, d'abord arbitraires (tel aspect de la langue parlée est reproduit et non tel autre), mais qui fonctionnent sur le plan intratextuel em tant que signes motivés, c'est-à-dire comme effect de mimésis sociolectale et/ou idiolectale à fonction identificatrice et idéologique. (Lane-Mercier, 1989, p. 172 apud Lavoie, 1994, p.127)

A autora sugere que a composição das redes de redundância dá-se, na verdade, na escolha de signos motivados, aqueles mais representativos na fala de determinada comunidade sociocultural: os signos que trazem em si o poder de identificar tal grupo e lançar sobre ele determinada visão político-ideológica. Em A Confederacy of Dunces, o BEV de Burma Jones é fator de identificação étnica do enunciador, bem como de sua posição social. Ao depararmos com a linguagem de Burma Jones, reconhecemos de imediato que ali não há o emprego do inglêspadrão. Toole habilmente recriou no diálogo literário do personagem os fatores sociais que influenciam a linguagem de Jones, principalmente no uso sistemático de traços gramaticais e fonológicos da variedade não-padrão que constituem o BEV, e de um registro informal, que é representado por uma ortografia em desacordo com as normas institucionalizadas. Burma Jones é negro, pobre e analfabeto, e a suas escolhas lingüísticas denunciam a posição socioeconômica e cultural ocupada por ele no romance e sua correlação fora do texto. Azevedo atenta igualmente para o aspecto identificador do dialeto literário:

Haveria de considerar também a relação entre a temas de etnicidade e identidade lingüística, individual ou coletiva, e analisar o dialeto literário como uma maneira de projetar a figura do "subalterno"- o morador do campo, o favela, o proletário, o imigrante - e indagar sobre a motivação de cada representação, e o seu possível impacto sobre os leitores. ( Azevedo, 2002, p. 141) 
A motivação autoral e o impacto sobre os leitores, por seu lado, referem-se à função ideológica dos dialetos literários. Na opinião de Lane-Mercier, os socioletos literários atestam “the author's own sociolinguistic positioning and foregrounds his or her ideological and political agenda"( Lane-Mercier, 1997, p. 47). Apesar de a opinião da autora coincidir com a de Ives no que diz respeito a considerar a linguagem padrão no texto literário como sendo a linguagem praticada pelo próprio autor, Lane-Mercier sugere que, para entendermos a função ideológica do socioleto literário, é necessário "to look beyond the aesthetic effects" (Ibidem, p.47), e considerar "the authorial values and attitudes" (Ibidem, p. 47) que os socioletos deixam transparecer. A autora sugere que indaguemos se o autor trata o personagem dialetal de maneira condescendente, distante ou solidária, entre outras atitudes. No ato de leitura, o tratamento dado pelo autor à recriação dos elementos sociolingüísticos fornece ao leitor uma primeira avaliação ideológica dos sujeitos representados, que poderá ser acatada ou descartada posteriormente. O resultado desse movimento é que o dialeto literário seria um construto textual privilegiado, ao oferecer espaço à aplicação

(...) of writing and reading strategies whose aim is to incarnate, in conjunction with specific ideological and political aims, the socio-cultural identity of fictitious speakers presented as positive or negative, or both positive and negative cultural Others. (Ibidem, p. 47)

Uma das facetas da representação negativa do personagem está associada à função humorística do dialeto literário, como vimos acima, construída largamente com base nos processos fonológicos desviantes. Contudo, na análise que fiz da fala do negro Jones, o humor não deprecia o personagem, corroborando as idéias de Lane-Mercier quanto aos aspectos ideológicos do socioleto literário, os quais é preciso observar além do efeito estético. Ao 
analisarmos a representação conferida por Toole à fala de Burma Jones apenas no aspecto de sua construção formal, talvez possamos concluir que ele está sendo depreciado pelo autor, uma vez que é impossível não se divertir com o modo de falar do negro. No entanto, o que faz a diferença na representação do negro é notar que o autor entregou ao personagem mais "negativamente" marcado no aspecto lingüístico a função de porta-voz do discurso anti-racista. Quando Toole escreveu o romance, o movimento pelos direitos civis nos EUA estava em marcha, e Burma Jones, como demonstramos no Capítulo I, é o porta-voz desse aspecto da sociedade norteamericana de meados do século XX.

Nos EUA, o dialeto literário apareceu em íntima conexão com o humor, na segunda década do século XIX. O alvo dos escritores era o homem comum, o cidadão que surgia com o avanço das fronteiras, associado à administração do primeiro presidente democrata, Andrew Jackson (1829-1837). Daí até mudar de mira e focar os negros foi questão de poucas décadas, quando teve início a tradição do “Old South western’humor” (Minnick, 2004, p. 4). Minnick explica que "perhaps more than in any other literary culture, the functions and traditions of literary dialect in the United States are closely associated with humor" (Ibidem, p.1). Burma Jones faz parte dessa tradição, sendo construído, com a superexploração dos desvios fonéticos e morfossintáticos, sobre o arquétipo da fala do negro norte-americano.

Neste capítulo busquei apontar como se dá a construção do dialeto literário no nível formal e quais as conseqüências semânticas desse artifício na narrativa. Das peculiaridades fonéticas, lexicais e gramaticais eleitas pelos autores para caracterizar a fala de determinado grupo sociocultural, constatei que as originadas em desvios fonéticos são as que mais têm sido empregadas na representação ficcional da fala do negro, ao mesmo tempo que alguns autores consideram esse desvio o mais pejorativo em relação à representação do personagem. Dos processos fonológicos nasce o humor e a associação com personagens de baixa escolaridade. Desde a tradição da "língua de preto", iniciada na literatura portuguesa do século XV e praticada 
até meados do século passado, as alterações fonéticas foram responsáveis pela identificação do negro em nossa tradição literária. Discuti, igualmente, como a fala do negro vem sendo retratada por escritores contemporâneos, em romances e contos que abordam as várias facetas da discriminação social, econômica e racial. Nesses autores, os personagens negros são menos marginalizados porque os marcadores dialetais estão menos na fonologia do que na escolha do léxico e dos desvios gramaticais, além de que, nessas novas representações, os narradores também são usuários de uma variante não-padrão da língua, o que faz toda a diferença.

\section{CAPÍTULO III}

\section{BURMA JONES: SABOTAGEM TRADUZIDA}

As traduções, como nós, e tudo o que nos cerca, não podem deixar de ser mortais.

Rosemary Arrojo

Como analisado no capítulo anterior, na construção do dialeto literário o autor elege marcadores fonéticos, gramaticais e de interação, resultando nas funções humorística, representativa e ideológica; ou seja, a marcação lingüística determina o resultado estético e ideológico do dialeto literário. Quanto à elaboração da fala dos negros na literatura, vimos que recursos fonéticos, como o eye-dialect, são os que mais negativamente caracterizam o personagem, sua baixa escolaridade, sua inferioridade cultural e social em relação aos outros personagens e ao narrador. Por outro lado, também foi possível observar que os escritores contemporâneos vêm abandonando tal caracterização, transferindo a marcação para o léxico e a sintaxe, assim abandonando a maneira tradicional de representar o negro na literatura.

Neste capítulo, dando prosseguimento à discussão acerca dos dialetos literários, acrescento o fator da tradução, o que agrega um complicador à representação da heterogeneidade lingüística no âmbito da ficção. A tradução das variedades dialetais é um tópico controvertido, exigindo de tradutores e teóricos da tradução certa dose de maleabilidade no trato com o corpus e com a crítica produzida e/ou recebida a partir de sua tradução. Ao criar uma ponte permanente e de mão dupla entre os estudos lingüísticos e a literatura, a representação literária da heterogeneidade lingüística, quando acrescida de uma terceira via, a tradução, gera outros desafios e caminhos. 
Dos teóricos contemporâneos da tradução, abordarei com mais ênfase as idéias da canadense Gillian Lane-Mercier apresentadas em "Translating the Untranslatable: The Translator's Aesthetic, Ideological and Political Responsibility", datado de 1997. A escolha justifica-se por exercer o texto influência direta na concepção de tradução que discuto aqui e na estratégia tradutória que desenvolverei para os diálogos de Burma Jones ao final do capítulo. Lane-Mercier, em sua reflexão pós-moderna, sugere que a tradução ultrapasse as dicotomias apresentadas por teóricos da tradução como Lawrence Venuti $(1986,2002)$ e Antoine Berman (2003) e seja entendida como o resultado de uma posição ética do tradutor, "his or her responsibility and engagement with respect to the choices for which he or she opts, and the aesthetic, ideological and political meanings these choices generate" (Lane-Mercier, 1997, p. 63). Por isso, este trabalho distancia-se das análises ligadas à lingüística mais estrita e aproxima-se das que entendem a tradução como uma questão discursivo-cultural, de acordo com a separação sugerida por Sariam em sua dissertação sobre tradução dialetal. A pesquisadora agrupa, de um lado, os autores ligados à lingüística contrastiva e à sociolingüística, respectivamente Catford e Bortoni e Tarallo, e de outro, Lavoie, Vidal, Brodsky e Lane-Mercier, cuja ênfase de análise recai sobre os valores culturais e políticos que norteiam o trabalho do tradutor (Sariam, 2002, p. 16).

A tradução que se segue à discussão teórica apresenta as falas mais relevantes de Burma Jones no correr da narrativa de A Confederacy of Dunces. O negro terá diferentes interlocutores, o que enriquece o texto, além de oferecer a oportunidade de propor a tradução de outros personagens. Após cada bloco de tradução, teço comentários sobre os aspectos mais problemáticos do texto, oportunidade em que justifico minhas escolhas.

\subsection{A ética na tradução de dialetos literários}

Lane-Mercier inicia seu artigo "Translating the Untranslatable: The Translator's Aesthetic, Ideological and Political Responsibility" afirmando ser unânime entre os teóricos contemporâneos da tradução a concepção de que a tradução é um ato que reproduz e produz sentido por meio da dupla dialética fidelidade/ transformação e perda/ganho, ainda que haja divergências entre os autores quanto ao conceito de fidelidade, à natureza da transformação, ao tipo de sentido que se ganha ou se perde e ao próprio papel do tradutor nesse processo. Tal 
concepção sustenta-se nos estudos recentes da tradução, sob o viés de teorias pós-modernas, onde as noções de original, equivalência e fidelidade são contestadas.

Em Tradução e Diferença (1999), Rodrigues apresenta a perspectiva pós-estruturalista desses três valores, explicando-nos, com base nas obras de Fish e Derrida, como ela se aplica à tradução. Em relação aos conceitos de "texto original" e "texto fonte", essa autora lembra-nos que o signo lingüístico, a partir das idéias de Saussure, passou a ser entendido não como a representação de algo conhecido pela experiência, como se acreditava na Antiguidade e na Idade Média, mas "em relação ao que o diferencia dos demais signos do sistema” (Rodrigues, 1999, p. 187). Dessa maneira, os textos, compostos de signos, não possuem um significado fechado, imutável, com um sentindo intrínseco, mas depreendido segundo a relação entre significante e significado, sendo essa relação "sempre contingente e dependente de espaço e tempo" (Ibidem, p.204). Pensando na tradução, Rodrigues afirma que

Visto por esse ângulo, o chamado texto-fonte não pode estar carregado de sentido, só pode ser movimento, heterogeneidade e, da mesma maneira que os signos, não é recuperável enquanto pura origem, mas efeito produzido no movimento dos signos. Se a cultura não é fonte das representações, mas seu efeito; se a representação não domina nem oculta o referente, ela cria e interpreta esse referente, sem oferecer um acesso imediato a ele, o tradutor não lida com uma "fonte", nem com uma "origem" fixa, mas constrói uma interpretação que, por sua vez, também vai ser movimento e desdobrar-se em outras interpretações. (Ibidem, p. 203)

O "texto-fonte" não pode ser entendido como "fonte transparente de significados" (Ibidem, p.204), pois é "signo de signo" (Ibidem, p. 204), e não um receptáculo de significado permanente e passível de ser transportado para uma outra língua. O contexto histórico torna-se relevante uma vez que não há "significado que transcenda as circunstâncias e a história de sua leitura e que esteja, de alguma maneira, protegido da diferença e da mudança” (Ibidem, p.178). Sob essa perspectiva, os conceitos de equivalência e fidelidade ficam comprometidos. Para Arrojo, ao se abandonar a idéia de que o texto tem sentido a ser desvendado, e ao se entender o ato de leitura como o resultado da inserção do texto numa estrutura de interpretação previamente estabelecida, determinada por estratégias discursivas pertencentes a dado momento histórico, não há como responsabilizar o tradutor pela falta de fidelidade ou por ele não ter encontrado uma solução "equivalente" para determinado aspecto do texto de partida: 
(...) ainda que um tradutor conseguisse chegar a uma repetição total de um determinado texto, sua tradução não recuperaria nunca a totalidade do "original"; revelaria, inevitavelmente, uma leitura, uma interpretação desse texto que por sua vez será, sempre, apenas lido e interpretado, e nunca totalmente decifrado ou controlado. (Arrojo, 2000, p.22)

Se ler e interpretar são o resultado de estratégias pré-estabelecidas, determinadas historicamente, a tradução, por sua vez, irá reproduzir e produzir sentidos delatores da posição social do tradutor no âmbito das estratificações socioideológicas de sua cultura, seus valores e crenças, as imagens e as atitudes culturais em circulação no contexto social em que ele está inserido. Desse processo, resulta que as estratégias discursivas assumidas pelo tradutor serão indicadoras das possibilidades interpretativas disponíveis aos leitores do texto de chegada e que as escolhas tradutórias revelarão o compromisso estético, ideológico e político do tradutor.

Um exemplo de como os tradutores manifestam sua agenda política e ideológica é a tradução feminista, citada no estudo de Moreno e Oliveira. Em artigo sobre a "tradução subversiva", os autores defendem que, dentre as possibilidades discursivas disponíveis no contexto histórico e ideológico em que se realiza a tradução, o tradutor opta por manter-se ligado aos conceitos mais tradicionais de "fidelidade" e "original" ou por assumir uma posição "subversiva". No domínio da tradução, subverter é "ser fiel a certos aspectos do original não lidos ou não enfatizados por outras traduções" (Moreno e Oliveira, 2000, p. 133), é o resultado de uma leitura que valoriza outros elementos do original, que não aqueles determinados pelo discurso dominante. Assim, no domínio da ideologia, os autores citam a prática tradutória de discurso feminista, em que as tradutoras assumem "uma postura de inequívoca intervenção no original" (Ibidem, p.136), modificando conscientemente o texto de partida com vistas a colocar em prática o discurso feminista contra o "texto original, geralmente tido como sexista, como parcial” (Ibidem, p.135). A intervenção do tradutor, nesse caso, é explícita:

A assinatura da tradutora indica ao leitor que a tradução realizada é explicitamente apropriada: a tradutora feminista torna feminista, via tradução, o que não é necessariamente feminista no original. (Ibidem, p.135)

Embora este pareça ser um caso extremo de destaque da estratégia discursiva, Moreno e Oliveira salientam que "a ideologia do tradutor está sempre presente em todas as traduções, e não apenas naquelas que se declaram "subversivas"” (Ibidem, p. 152). Com isso, validam a defesa que Lane-Mercier faz da "onipresença" do tradutor em cada "vírgula" de sua tradução, uma vez 
que traduzir é uma prática ética que envolve não apenas a produção de sentido, mas também a responsabilidade estética, ideológica e política do tradutor. Diferentemente desses autores, a pesquisadora canadense elegeu a problemática da tradução de dialetos literários para exemplificar como em toda tradução acontece um engajamento "violento" do tradutor na produção de sentido. A tradução de socioletos literários, diz ela, é paradigmática em relação à tradução em geral pela forma como o tradutor suplementa, apaga, transforma, subverte, parodia o sentido do texto-fonte por meio de estratégias tradutórias específicas. Dessa maneira, uma tradução sempre manifestará a presença "violenta" do tradutor.

No capítulo II, vimos que para Lane-Mercier os dialetos (a autora trabalha com o termo socioleto) aparecem em discurso direto, na fala de várias personagens de uma obra, cujas configurações fonética, sintática, lexical e/ou semântica são, quase sempre, arranjadas de forma a mostrar esses personagens negativa ou depreciativamente em relação ao discurso social "neutro", "correto". Para que sejam facilmente reconhecidas pelos leitores, o autor seleciona as marcas dialetais mais salientes de determinado grupo social, usando-as em quantidade excessiva no texto. A autora argumenta que a adequação do fenômeno de fala extratextual ao projeto estético do escritor não é uma questão apenas de diferença lingüística, mas de "social and cultural representations of the Other (...), as well as the underlying interests and power struggles upon wich such representations are constructed" (Lane-Mercier, 1997, p.46).

Diante dessa observação, fica exposta a intervenção "violenta" com a qual os dialetos literários integram a obra de ficção. O texto de partida carrega a presença marcante do autor na construção dos dialetos literários, o que, por sua vez, produz uma forte sugestão na leitura, cujo objetivo é "to oriented (or disorient) the reading by generating aesthetic, ideological and political meaning" (Ibidem, p.48). Na tradução, os dialetos estão saturados da presença do tradutor, resultando na criação de sentidos estético, político e ideológico que exprimem a visão do Outro cultural pelo prisma da língua-alvo. Em outras palavras, quando um texto marcado por dialetos literários é traduzido, ocorre uma dupla violência: a primeira, inerente ao próprio ato de representação das configurações lingüísticas marcadas socialmente; a segunda, resultado da transformação operada pelo tradutor.

Uma vez constatado que traduzir é um processo "violento" de produção de sentido, no qual estará sempre registrada a presença igualmente "violenta" do tradutor, Lane-Mercier questiona a dicotomia dos conceitos de visibilidade versus invisibilidade apresentados por Lawrence Venuti 
(1986) e as críticas positiva versus negativa sugeridas por Antoine Berman (2002). Os dois autores apresentam dicotomias bastante rígidas acerca das estratégias tradutórias, as quais passo a discutir.

Em um texto considerado quase canônico, Venuti criticou a invisibilidade do tradutor. Esta consistiria, em termos de estratégia tradutória, na aclimatação das especificidades lingüísticas e culturais do texto-fonte, com vistas a tornar a leitura fluente, dessa maneira "an effect of transparency" (Venuti, 1986, p.187); o tradutor exime-se de contestar os valores estéticos e ideológicos de sua cultura, fato que, por outro lado, "eclipses the translator's labor" (Ibidem, p. 181). No outro extremo, está o tradutor visível, aquele que, ao adotar uma estratégia resistente "that foregrounds the materiality of the text as a translation" (Ibidem, p.190), rompe com os valores estéticos e ideológicos de fluência e transparência textuais, adotando uma estratégia que faz uso de "anacronismos, de construções gramaticais e lógicas não-padrão ou marginais, realçando a heterogeneidade cultural, a ambivalência ou descontinuidades do discurso" (LaneMercier, 1997, p.58), com o objetivo de frustrar a expectativa etnocêntrica do leitor.

Em relação aos dialetos literários, no primeiro capítulo de Escândalos da Tradução, Lawrence Venuti expõe sua agenda política para a tradução, apresentando-nos seu projeto minorizante, no qual desenvolve a idéia de que a tradução deve apresentar uma heterogeneidade discursiva, obtida por meio da liberação do "resíduo" da língua. Por resíduo o autor entende as formas da língua que são subjugadas pela forma padrão, as variedades de baixo prestígio, pois a língua "nunca é simplesmente um instrumento de comunicação" (Venuti, 2002, p.24), mas um sistema de signos cuja estrutura hierárquica é determinada historicamente. Venuti assevera que

A boa tradução é a minorizante: libera o resíduo ao cultivar o discurso heterogêneo, abrindo o dialeto-padrão e os cânones literários para aquilo que é estrangeiro para eles mesmos, para o subpadrão e para o marginal. (Ibidem, p.28)

À primeira vista, parece-nos uma tarefa fácil seguir a sugestão de Venuti; contudo, ao sugerir a liberação do resíduo, o autor ressalta não estar se referindo à concepção de "uma língua menor como um mero dialeto" (Ibidem, p.28), com isso evitando a identificação com uma comunidade cultural específica, mas à utilização de elementos minoritários estrategicamente espalhados pelo texto, o que, citando Deleuze e Guattari, inventaria "uma formação específica, 
inédita, autônoma" (Ibidem, p. 28). O objetivo de Venuti é sempre o de diferenciar a linguagem da tradução para que o leitor perceba que está lendo um texto traduzido.

Mas, ao comentar a tradução de Ben Belitt para o inglês da peça em verso Splendor and Death of Joaquín Murieta, do chileno Pablo Neruda, Venuti elogia a escolha de um dialeto da costa oeste dos EUA para dar voz aos imigrantes chilenos, o que me parece contradizer seu apelo por não se referir diretamente a uma "comunidade cultural específica". De qualquer forma, o caso exemplifica seu entendimento do que seria uma estratégia que visaria à visibilidade do tradutor, ou à estratégia resistente:

In the end, what determines whether an English translation of Neruda's play is progressive or reactionary is a decision about translation strategy; fluency leads to the choice of a distinctive, realistic dialect for the Chileans because realism makes the text unequivocal and therefore readable for a North American audience, satisfying expectations that the aliens will have a cultural naiveté and inviting a condescending dismissal of, or merely a sentimental sympathy for, resistancy leads to the choice of a western dialect for the Chileans because the resulting linguistic discrepancy distances North Americans, frustrating ethnocentric expectations and forcing a more careful consideration of the aliens and possibly some self-reflection and revaluation. (Venuti, 1986, p. 207)

A proposta de Venuti enfatiza que a estratégia tradutória oferecida pelo tradutor é o "chão" sobre o qual crescerão as respostas do público, que podem ser de confortável reconhecimento de algo aceito como "real", no caso da tradução dos imigrantes chilenos da peça de Neruda "a mixture of colloquial English and Hispanicisms" (Ibidem, p.206), ou a opção de Belitt, a resistência, alcançada pelo uso de um dialeto da costa oeste norte-americana, onde a peça é ambientada. Ao sugerir o emprego da segunda opção, Venuti acredita que o tradutor esteja oferecendo um produto de "difícil digestão", com isso provocando um momento de reflexão no leitor/platéia.

De acordo com a reflexão do teórico e tradutor americano, o engajamento discursivocultural do tradutor na tradução de dialetos deve minar o etnocentrismo do público-alvo. Outro teórico da tradução que compartilha dessa idéia é Antoine Berman, que condena abertamente a tradução etnocêntrica, denominando-a de "má” tradução" (Berman, 2002, p.17). Berman acredita que hoje em dia há certas "resistências" (Ibidem, p.16) em se deixar que uma língua "nacional" seja "contaminada" por línguas estrangeiras, num esforço de evitar a "violência da 
mestiçagem” (Ibidem, p.16) que ocorre na tradução. Aí reside a importância do que o autor denomina "visada da tradução", um movimento de abertura da língua para o que lhe é estrangeiro:

Toda cultura resiste à tradução mesmo que necessite essencialmente dela. A própria visada da tradução - abrir no nível da escrita uma certa relação com o Outro, fecundar o Próprio pela mediação do Estrangeiro - choca-se de frente com a estrutura etnocêntrica de qualquer cultura, ou essa espécie de narcisismo que faz com que toda a sociedade deseje ser um Todo puro e não misturado. (Ibidem, p. 16)

A visada da tradução defendida por Berman é alimentada pelo que o autor denomina ética positiva intrínseca da tradução, ao passo que negar a abertura do vernáculo para as línguas estrangeiras, à mestiçagem das línguas, representa o lado negativo da tradução, sendo considerada uma ética negativa. As idéias de Berman operam quase que em sintonia com as dicotomias apresentadas por Venuti, já que, para o teórico e tradutor francês, a crítica positiva da tradução alinha-se com a prática discursiva "literal", ao entender que "a essência da tradução é ser abertura, diálogo, mestiçagem, descentralização" (Ibidem, p. 17). Os recursos empregados para atingir esse objetivo assemelham-se aos de Venuti, quando não são até mais radicais, uma vez que Berman sugere que a tradução intensifique ainda mais o que há de estranho no textofonte. Novamente, espera-se decepcionar os leitores em relação às suas expectativas de leitura e seus estereótipos culturais, bem como ampliar as possibilidades estéticas da língua-alvo. A essa estratégia contrapõe-se uma prática tradutória que opera "uma negação sistemática da estranheza da obra estrangeira" (Ibidem, p.18), numa tradução que privilegia o conteúdo e aclima o estrangeiro aos padrões estéticos da língua-alvo.

Aplicando os conceitos acima à tradução de socioletos literários, é possível notar que para Venuti e Berman as estratégias recomendadas seriam a da visibilidade do tradutor e a da crítica positiva, respectivamente. No entanto, Lane-Mercier parte dessa mesma aplicação para contestar não os conceitos em si, mas como essas idéias ajudam na manutenção da rigidez das dicotomias perda/ganho e fidelidade/transformação. Em Venuti, a autora salienta a limitada validade da idéia de visibilidade versus invisibilidade do tradutor, uma vez que o tradutor está sempre presente no texto traduzido, e nunca realmente invisível; trata-se apenas de uma "illusion of transparency" ( Lane-Mercier, 1997, p. 58), sendo a invisibilidade do tradutor uma estratégia tanto quanto a visibilidade. A pesquisadora canadense acrescenta que a proposta de Venuti não 
cobre todas as especificidades de um texto, acontecendo de ora o tradutor empregar a estratégia fluente, ora a resistente, e julgar essas estratégias depende do momento histórico.Quanto à ética positiva e negativa de Berman, Lane-Mercier discorda da relevância que a noção de "fidelidade" ao texto-fonte assume na proposta de tradução valorizada pelo autor, visto que a tradução é um processo sujeito a perdas e ganhos semânticos, pois a falta de equivalência entre as culturas envolvidas é um fato. Na prática de tradução "literal", ela acredita que Berman incorre numa atitude elitista, ao se recusar a traduzir para o público em geral. A pesquisadora aponta para o "caminho do meio":

Each "dichotomy" must therefore be seen less in terms of mutually exclusive opposites than in terms of translation strategies that may all come into play, for different reasons, at different textual sites, with varying effects, in the course of the translation process. And rather than systematically seeing one pole as negative ("wrong", "bad") and the other as positive ("correct", "good"), one must point out to the historical variability and the potential interchangeability of the two poles. (Ibidem, p.56)

Ainda com base na polaridade de valores atribuídos à prática tradutória e seus resultados, grande parte da crítica produzida em relação à tradução de dialetos literários se mantém presa aos conceitos de equivalência e fidelidade, sendo que o foco dos comentários está sempre no lado negativo do resultado da empreitada. Os tradutores são cobrados de gerar associações equivocadas de sentido na língua de chegada, e os críticos atribuem valor negativo às associações escolhidas pelo tradutor; de perder o sentido cultural e político do texto original, como se fosse possível encontrar equivalência cultural e política entre as comunidades falantes das línguas envolvidas na tradução; de o tradutor apresentar uma atitude etnocêntrica, domesticando o conteúdo em detrimento da forma; de faltar com autenticidade na recriação de um dialeto real por um artificial, estilizado e estereotipado, opinião que revitaliza a dicotomia original-autêntico/tradução-“fake” ou inautêntico.

Além de apresentar as críticas supracitadas, Lane-Mercier contesta as opções conservadora ou radical sugeridas por André Levefere (1992). O autor classifica de estratégia conservadora (negativa) aquela que se mantém fiel às construções gramaticais do original, em oposição a uma estratégia radical (positiva), na qual entram em cena jargões e atualizações da linguagem com base na cultura de chegada. Mais uma vez, a autora observa que ser conservador ou radical dependerá, entre outros fatores, da origem do tradutor, de sua posição sociocultural, do resultado da interpretação estética, ideológica e política do 
socioleto no texto-fonte (é realista? irônico? denuncia ou afirma os estereótipos culturais?), e do público que a tradução pretende atingir. Não é possível pensar apenas numa divisão rígida e simplista entre conservador ou radical.

Chegando-se à proposta de Lane-Mercier, a sugestão é de que as dicotomias devam ser suplantadas, pelas várias razões apontadas anteriormente. A autora propõe que tenhamos conhecimento da existência desses valores, mas que não limitemos nossas estratégias de tradução nem nosso julgamento sobre as mesmas em termos dessas dicotomias. A proposta da autora é a de transferir para as mãos do tradutor a responsabilidade de seu posicionamento frente a essas dualidades. Em outras palavras, Lane-Mercier sugere o questionamento não do resultado das estratégias tradutórias, sejam elas fluente ou resistente, positiva ou negativa, mas do sujeito que as colocou em ação:

(...) what is always already at stake in the translation process is neither the visibility vs the invisibility of the translator nor the ethical aim of translation per se, but rather the translator's own ethical code, his or her responsibility and engagement with respect to the choices for which she or he opts and the aesthetic, ideological and political meanings these choices generate (Lane-Mercier, 1997, p. 63)

Sob esse novo prisma, a ética na tradução refere-se à escolha que o tradutor faz entre dissimular ou reconhecer a manipulação que ele opera no texto-fonte e às conseqüências estéticas, ideológicas e políticas dessa atividade, ao passo que o tradutor invisível é aquele que se exime da responsabilidade de sua manipulação textual, deixando de refletir sobre os efeitos estéticos, ideológicos e políticos que ele coloca em circulação dentro da sua comunidade. Ou, nas palavras de Rodrigues, é preciso entender a tradução

(...) como uma atividade que se expõe como produto humano, como produto de uma interpretação, de uma perspectiva, que evidencia as diferenças entre as línguas, exibe sua nãoneutralidade. As polarizações propostas ocultam que a tradução é um processo de escolha, uma atividade interpretativa, em que o lingüístico se associa ao contextual em seu sentido mais amplo, incluindo o histórico e o social. Essas polarizações encobrem que toda tradução depende da "criatividade" do tradutor, ou seja, de sua capacidade de produzir significados aceitáveis para uma comunidade leitora. É impossível repetir significados porque não se retorna ao idêntico: novas situações, novos comentários, novas relações intertextuais sempre se instauram em uma leitura. (Rodrigues, 1999, p. 213)

Apesar de a responsabilidade última ser do tradutor, há que se considerar que nem sempre o tradutor tem autonomia para empregar numa tradução as estratégias que lhe pareçam melhores. 
Nesse caso, refiro-me às normas e exigências das editoras, aspecto apontado por Milton ao tratar da tradução dos dialetos literários. Ao indagar o porquê de os dialetos literários não serem traduzidos, o autor apresenta argumentos ligados a questões gerais, como a alegação “essencialista”, "platônica” (Milton, 2002, p. 55) de que o conteúdo é mais importante do que a forma, e a fatores específicos da situação da tradução literária no Brasil. Quanto aos últimos, Milton destaca a falta de tradição de romances proletários, o tardio desenvolvimento dos estudos dialetológicos, o conservadorismo das editoras, quase sempre um "negócio familiar que evita novidades" (Ibidem, p. 58); o fato de os romances clássicos fazerem parte da grade curricular; e, não menos importante, a baixa remuneração salarial dos tradutores no Brasil. $\mathrm{O}$ ambiente acadêmico, segundo Milton, surge nesse cenário como um "oásis", onde é possível traduzir apoiado em pesquisas, espaço no qual se insere este trabalho.

\subsection{Proposta de tradução para Burma Jones}

Conforme citado anteriormente, a pesquisadora e tradutora canadense Gillian LaneMercier foi a autora que mais influenciou a elaboração da estratégia tradutória que colocarei em prática. Embora ela não prescreva uma estratégia de tradução, suas idéias nos levam a refletir sobre a responsabilidade de nossa atividade como tradutores em um nível mais abrangente que apenas o textual. Após a leitura de seu artigo, perguntei-me qual o grupo sociocultural que eu gostaria de representar na tradução e quais seriam as conseqüências de minha escolha. Apesar de o livro de John Kennedy Toole não primar por uma abordagem politicamente correta sobre as diferenças étnicas, pois o falar de Burma Jones, em certos aspectos, pode aproximar-se do que Lane-Mercier aponta como uso depreciativo do socioleto em relação ao discurso neutro do narrador, a qualidade cômica do personagem é balanceada pelo "conteúdo" que ele veicula, pois, como afirma o escritor Walker Percy no prefácio de A Confederacy of Dunces, com Burma Jones "Toole atingiu o quase impossível, um soberbo personagem cômico de grande perspicácia e inventividade” (Toole, 1987, p. 9). A partir dessas observações, escolhi marcar a fala de Burma Jones na tradução tendo como uma das referências o falar dos jovens da periferia da cidade de São Paulo, representado ficcionalmente nos romances de Ferréz, Capão Pecado e Manual

Prático do Ódio. Nesse aspecto minha estratégia tradutória remete ao projeto minorizante 
de Venuti, uma vez que, para traduzir o romance gótico Fantastic Tales, de Tarchetti, o tradutor recorreu à tradição gótica britânica e inglesa. Ao detalhar a estratégia tradutória empregada, Venuti explica que "revisitou" trabalhos de Mary Shelly e Poe "em busca de palavras e frases que pudessem ser incorporadas na tradução" (Venuti, 2002, p.33).

Os livros de Ferréz são um retrato do cotidiano violento de uma das regiões mais miseráveis da capital paulista, o Capão Redondo, no extremo Sul da cidade, e um registro do embrutecimento do homem e de sua linguagem. Dessa forma, a obra de Ferréz é um trabalho bem realizado de inserção da linguagem oral na literatura. Burma Jones e os personagens de Capão Pecado e Manual Prático do Ódio apresentam algumas semelhanças socioeconômicas e étnicas: são negros, analfabetos ou semi-analfabetos, desempregados e excluídos de suas respectivas sociedades. É essa associação e esse parentesco de infortúnio que procuro reproduzir na tradução. A representação da oralidade foi a base sobre a qual empreguei os marcadores mais significativos da fala desses jovens ficcionais, e para isso empreguei elementos lexicais e gramaticais da linguagem coloquial, além de elementos ligados à situação de interação.

Na construção lingüística do falar de Burma Jones, optei por manter um alto índice de marcação fonética, o que gera grande associação com o humor e vai contra as representações do negro na literatura atual, como demonstrado no capítulo anterior. Minha decisão justifica-se por ser Burma Jones um personagem cômico, o que, na minha opinião, não deve ser visto como uma característica depreciativa; ao contrário, a agilidade mental e a lucidez de suas observações suplantam o simples humor, sendo este até um ponto de realce de seu potencial intelectual. Pois, como bem afirma Azevedo, "mesmo uma intenção humorística não denota, a priori, ausência de um sentido mais profundo, porquanto, mesmo em casos de comicidade proposital" (Azevedo, 2003, p. 139).

\subsubsection{Burma Jones e Mr. Robichaux}

Na primeira participação do negro no romance, Burma encontra-se na delegacia com o velho Mr. Robichaux, sob a acusação de ter furtado um pacote de parafusos. Burma estranha o fato de um senhor respeitável estar na mesma situação em que ele. 
In the precinct the old man sat on a bench with the others, mostly shoplifters, who composed the late afternoon haul. He had neatly arranged along his thigh his Social Security card, his membership card in the St. Odo of Cluny Holy Name Society, a Golden Age Club badge, and a slip of paper identifying him as a member of the American Legion. A young black man, eyeless behind spaceage sunglasses, studied the little dossier on the thigh next to his.

"Whoa!" he said, grinning. "Say, you mus belong to everthin."

The old man rearranged his cards meticulously and said nothing.

"How come they draggin in somebody like you?" The sunglasses blew smoke all over the old man's cards. "Them po-lice mus be getting desperate."

"I'm here in violation of my constitutional rights," the old man said with sudden anger.

"Well, they not gonna believe that. You better think somethin else." A dark hand reached for one of the cards. "Hey, wha this mean, 'Colder Age'?"
$\mathrm{Na}$ delegacia, o velho estava sentado num banco com os outros, a maioria ladrões de lojas, produto do arrastão do final de tarde. Arrumara no colo, enfileirados com capricho, sua carteira da Previdência Social, a carteira de sócio da Sociedade São Odo de Cluny, um crachá do Clube da Idade de Ouro e um comprovante de filiação da Legião Americana. Um jovem negro, com óculos escuros modelo espacial, observava o pequeno dossiê na perna ao lado.

“Meu!'(1) disse o jovem num esgar. "Aí, cê (2) deve ser sócio de tudo, tá ligado (3)?”

O velho tornou a arrumar meticulosamente as carteirinhas, e nada disse.

“Como é que pode eles prendê (4) alguém como você?" Os óculos escuros lançaram uma fumaceira cobrindo todas as carteirinhas. "Os home deve tá no desespero."

"Eu estou aqui numa violação dos meus direitos constitucionais", disse o velho com ira súbita.

“Aí, eles não vai acreditá nessa. Melhor cê contá outra, tá ligado?" Uma mão escura apanhou uma das carteiras. “Meu, que quer dizer "Idade de Não Dá no Couro (5)"? 
Notas

(1) A fala de Burma Jones faz uso recorrente das interjeições whoa! , ooo-woo! e hey!. Interjeições são palavras e sintagmas de valor expressivo ou comunicativo, remetendonos a elementos suprassegmentais, como a entonação. Traduzi-as, respectivamente, por “ah-hum!” (usado pelo negro Leléu do romance Viva o Povo Brasileiro, de João Ubaldo Ribeiro), “ôxe!” e "meu!".

(2) Um dos efeitos fonéticos mais empregados na minha tradução é a supressão nas várias partes dos vocábulos. Tal efeito é recorrente em nossa literatura regional (Martins), na representação do registro coloquial (Urbano), e igualmente atribuído à influência da fala dos africanos no português do Brasil (Mendonça). Mendonça aponta as "aféreses violentas" (p. 63) atribuídas à fala dos negros, como ocê por você, e a apócope em /l / e /r/ finais, características que incluo na tradução.

(3) Os elementos fáticos, como a expressão "tá ligado", permearão o texto, reforçando os aspectos de oralidade, o temperamento intrusivo e marcante do personagem, por serem altamente representativas do grupo social ao qual busco associar o personagem Burma Jones.

(4) Outra marcação recorrente são os plurais impróprios, característica da economia da língua falada (Urbano), bastante retrata nos personagens dos livros Capão Pecado e Manual Prático do Ódio, de Ferréz. Mendonça considera que manter o substantivo invariável nos plurais é um "vestígio" (p. 67), na morfologia, da influência africana sobre o português do Brasil, conservada, na opinião do autor, na "linguagem dos caipiras e matutos"(p. 67). 
(5) Optei por "Idade de Não Dá no Couro" e não a tradução literal de "Idade Mais Fria" pela semelhança fônica entre "ouro" e "couro", remetendo à carteirinha do "clube da Idade de Ouro", provavelmente a que se referia Burma Jones.

(6) O emprego de elementos gírios reforça a fala de um determinado grupo social, sendo vocábulos marginalizados pela fala padrão. As gírias serão muitas na tradução: “mano", “firmeza”, “da hora”, “mó certeza”, “treta”, entre outras.

(7) O senhor Robichaux, filho de imigrantes, também apresenta sua idiossincrasia lingüística, que optei por representar com alterações fonéticas.

(8) Busquei manter o mesmo jogo entre som e sentido apresentado em "cawmniss", e a melhor solução foi "cãomunista".

(9) Fiquei em dúvida na tradução de "Angola"; primeiramente, mantive o nome próprio, mas encontrei, num trecho que apresento mais abaixo, Jones dizendo que não queria ir parar em Angola com a Lana Lee, que naquele momento estava presa. Concluí, então, que Angola é uma gíria para cadeia.

(10) Burma Jones usa o vocábulo gírio "mother", uma redução de "motherfucker", indiscriminadamente. Optei por traduções diferentes no correr da tradução. Neste momento, emprego "puto".

(11) Para manter algum nível de comicidade e o duplo sentido de "Nut House" (casa da castanha, hospício), encontrei a solução na tradução de "bag of cashew nuts" por "pacote de parafuso" e "Nut House" por "Casa do Pinel”, já que dizemos que louco tem sempre um parafuso a menos, e Pinel lembra pino e afins, além de ser o nome de um hospício famoso no Brasil.

(12) Traduzi por "segurança" o vocábulo inglês flo'walk (floorwalker), que numa tradução literal seria gerente de seção de loja de departamento, cuja função é 
supervisionar os vendedores e servir aos clientes. Minha escolha buscou a contextualização, uma vez que não estamos familiarizados com tal função nas lojas brasileiras.

(13) Marcação sistemática da redução de $n d$ em $n$, como caracterização da língua falada (Urbano). Em sua análise sobre a influência dos negros no português do Brasil, Mendonça explica que "[o] gerúndio, no dialeto de S.Paulo, perde o $d$ nas desinências, ando $->$ ano, endo $->$ eno, indo-> ino, ondo $->$ ono: andano, veno, caíno, pôno (Mendonça, 1973, p. 68). Quanto à origem dessas alterações, o autor afirma não haver um consenso entre os pesquisadores, sendo apontada por alguns como herança dos negros e por outros, influência da língua tupi.

(14) Buscando reproduzir a rapidez da fala, optei pela aglutinação de palavras gramaticais (Martins, 2000), como em “que'u” (que + eu) e “pra'quela” (para + aquela).

(15) Por uma questão de humor, recorri ao efeito do "eye-dialect" para o vocábulo inglês forever, numa intervenção mais forte de minha parte na tradução. Minha escolha remete à estratégia proposta por Venuti em que o autor sugere o uso de arcaísmos, de material lingüístico colhido em obras literárias, decalques e clichês atuais, com a intenção de quebrar a "ilusão realista da narrativa" (Venuti, 2002, p.40).

\subsubsection{Burma Jones e Lana Lee}

Para se manter longe da cadeia, Jones vai trabalhar na Boate Noite do Prazer. A relação conturbada com Lana Lee, a dona do estabelecimento, tem início. 


\begin{tabular}{|c|c|}
\hline $\begin{array}{l}\text { "I come about that porter job you got } \\
\text { advertise in the paper." }\end{array}$ & $\begin{array}{l}\text { "Aí, vim sabê da vaga de faxinêro (16) } \\
\text { que saiu no jornal." }\end{array}$ \\
\hline $\begin{array}{l}\text { "Yeah?" Lana Lee looked at the } \\
\text { sunglasses. "You got any references?" }\end{array}$ & $\begin{array}{l}\text { "É? - Lana Lee olhou para os óculos } \\
\text { escuros. - Você tem alguma referência?" }\end{array}$ \\
\hline $\begin{array}{l}\text { "A po-lice gimme a reference. He tell } \\
\text { me I better get my ass gainfully employ," } \\
\text { Jones said and shot a jet of smoke out into } \\
\text { the empty bar. }\end{array}$ & $\begin{array}{l}\text { “Os home me deu uma referência. } \\
\text { Aí, falo que'é melhor eu sossegá a bunda } \\
\text { num emprego remunerado (17), tá } \\
\text { ligado?”, disse Jones e lançou um jato de } \\
\text { fumaça dentro do bar vazio. }\end{array}$ \\
\hline $\begin{array}{l}\text { "Sorry. No police characters. Not in a } \\
\text { business like this. I got an investiment to } \\
\text { watch." }\end{array}$ & $\begin{array}{l}\text { "Sinto muito. Nada de tipos com } \\
\text { passagem pela polícia. Não num negócio } \\
\text { como este. Tenho um investimento a } \\
\text { zelar." }\end{array}$ \\
\hline $\begin{array}{l}\text { "I ain exactly a character yet, but I can } \\
\text { tell they gonna star that vagran no visible } \\
\text { means of support stuff on me. They told } \\
\text { me." Jones withdrew into a forming cloud. } \\
\text { "I thought maybe the Night of Joy like to } \\
\text { help somebody become a member of the } \\
\text { community, help keep a poor color boy } \\
\text { outta jail. I keep the picket off, give the } \\
\text { Night of Joy a good civil right ratin." }\end{array}$ & $\begin{array}{l}\text { “Aí, eu não sou bem um fichado } \\
\text { ainda, mas garanto que vão vim pra cima } \\
\text { de mim co'aquele negócio de tolerância } \\
\text { zero (18) cos vagabundo. Eles me falô, tá } \\
\text { ligado?” Jones recolheu-se à sua nuvem de } \\
\text { fumaça. "Aí, eu pensava que a Noite do } \\
\text { Prazê talvez ia querê ajudá um sujeito a } \\
\text { fazê parte da comunidade, ajudá a mantê } \\
\text { um moço de cor do lado de fora das grade. } \\
\text { Eu não deixo o piquete acontecê, a Noite } \\
\text { do Prazê fica beleza no quesito dos direito } \\
\text { civil.” }\end{array}$ \\
\hline
\end{tabular}




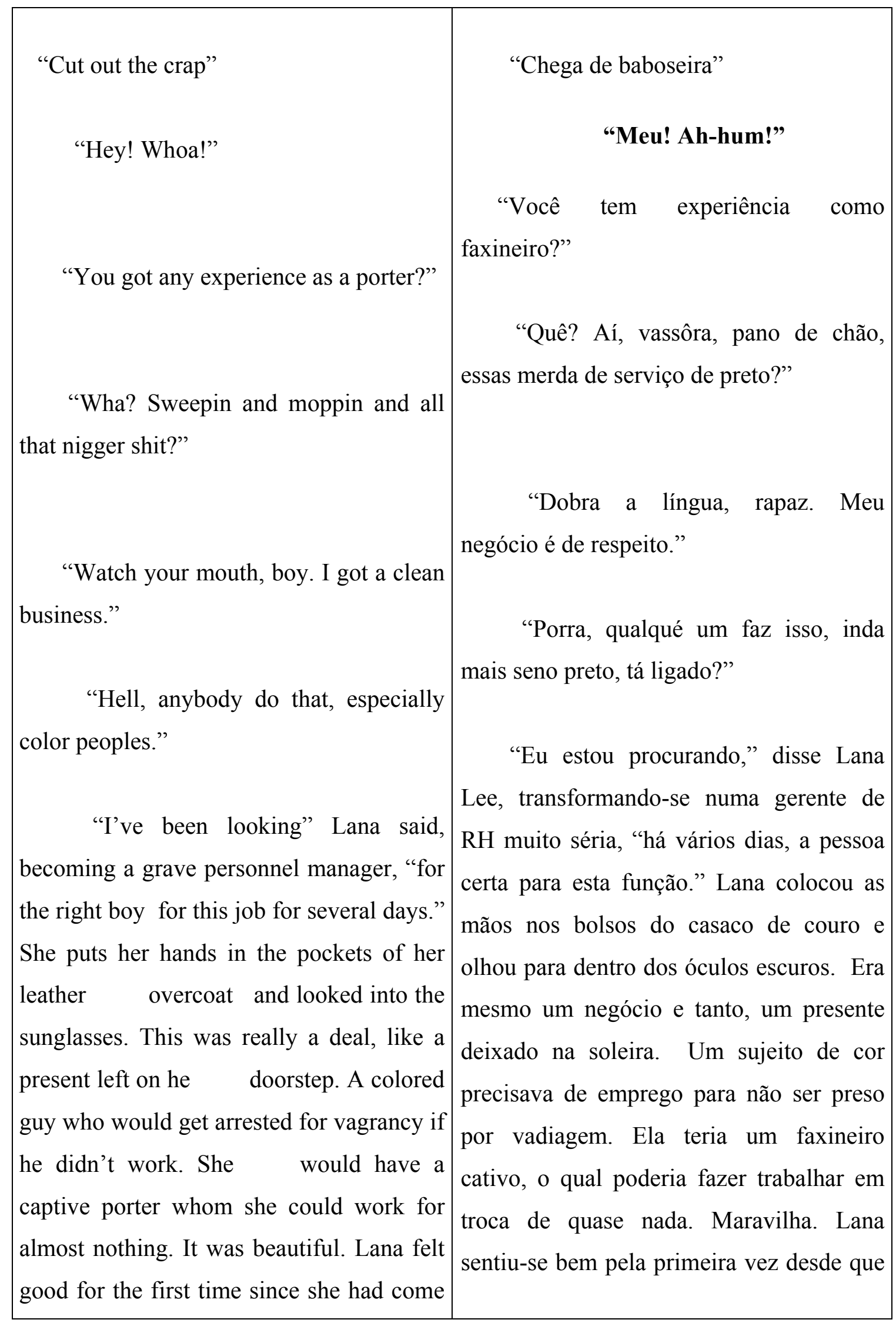




\begin{tabular}{|c|c|}
\hline $\begin{array}{l}\text { upon those two characters messing up her } \\
\text { bar. "The pay is twenty dollars week." }\end{array}$ & $\begin{array}{l}\text { aqueles dois haviam aparecido no bar } \\
\text { armando confusão. "O salário é de vinte } \\
\text { dólares por semana." }\end{array}$ \\
\hline $\begin{array}{l}\text { "Hey! No wonder the right man ain } \\
\text { show up. Ooo-wee. Say, whatever happen } \\
\text { to the minimal wage?" }\end{array}$ & $\begin{array}{l}\text { "Meu! Num é à toa que’o homem certo } \\
\text { não apareceu. Ôxe. Aí, que fim levô o } \\
\text { salário mínimo?” }\end{array}$ \\
\hline $\begin{array}{l}\text { "You need a job, right? I need a } \\
\text { porter. Business stinks. Take it from there. }\end{array}$ & $\begin{array}{l}\text { "Você precisa trabalhar, certo? Eu } \\
\text { preciso de um faxineiro. Os negócios vão } \\
\text { mal. É pegar ou largar." }\end{array}$ \\
\hline $\begin{array}{l}\text { "The las person workin in here musta } \\
\text { starve to death." }\end{array}$ & $\begin{array}{l}\text { "A última pessoa que trabalhô aqui } \\
\text { deve tê morrido de fome, tá ligado?" }\end{array}$ \\
\hline $\begin{array}{l}\text { "You work six days a week from ten } \\
\text { to three. If you come in regular, who } \\
\text { knows? You might get a little raise." }\end{array}$ & $\begin{array}{l}\text { "Você trabalha seis dias por semana, } \\
\text { das dez às três. Se aparecer todos os dias, } \\
\text { quem sabe? Talvez ganhe um } \\
\text { aumentozinho. }\end{array}$ \\
\hline $\begin{array}{l}\text { "Don worry. I come in regular, } \\
\text { anything keep my ass away from a po-lice } \\
\text { for a few hour," Jones said, blowing some } \\
\text { smoke on Lana Lee. "Where you keep } \\
\text { there mutherfucking broom? }\end{array}$ & $\begin{array}{l}\text { “Num esquenta, dona. Faço qualqué } \\
\text { coisa pra tirá meu cu da reta da polícia por } \\
\text { algumas hora, tá ligado?" disse Jones, } \\
\text { exalando fumaça em Lana Lee. "Onde cê } \\
\text { guarda a porra da vassôra? }\end{array}$ \\
\hline "One thing we gotta unders & "É bom ficar claro que aqui não se \\
\hline
\end{tabular}




\begin{tabular}{|c|c|}
\hline keeping our mouth clean around here." & palavrão.” \\
\hline $\begin{array}{l}\text { "Yes, ma'm. I sure donn wanna make } \\
\text { a bad impressia in a fine place like the } \\
\text { Night of Joy. Whoa!" }\end{array}$ & $\begin{array}{l}\text { "Pois não, madama (19). Eu com } \\
\text { certeza não quero causá impressãos (20) } \\
\text { ruim num lugar tão dos fino como a Noite } \\
\text { do Prazê. Ah-hum!"” }\end{array}$ \\
\hline (ACD, pp. 43-44) & \\
\hline
\end{tabular}

Notas

(16) Emprego na tradução outra característica apontada por Mendonça na influência do negro na fala do brasileiro, a redução dos ditongos ei e ou.

(17) Segundo o The Columbia Guide to Standard American English on line, a gainfully employed é "a cliché used to distinguish working for pay from working without compensation". Optei, igualmente, por usar a forma dupla de "emprego remunerado", ainda que redundante, pois a redundância é uma característica da língua falada.

(18) Neste trecho, optei por usar a expressão consagrada em português "tolerância zero" no lugar de "no visible means of support", mesmo não sendo esta a tradução da expressão em inglês. $\mathrm{Na}$ verdade, o que está em jogo nesse parágrafo é o termo "stuff”, que no caso significa uma ação policial que irá prender aqueles que não possuem um "ganha-pão", ou seja, os vagabundos, situação em que se encontra Burma.

(19) Optei por "madama" por ser por ser uma das marcações mais significativas quanto ao gênero em língua portuguesa (Martin, 2000), flexionar os substantivos de 
dois gêneros. Em português "madame" refere-se também a "mulher que pratica meretrício"e "gerente de prostíbulo" (Houaiss).

(20) Ao contrário da falta da desinência de plural, optei por "pluralizar" vocábulos com a intenção de reforçar a ironia de Jones.

A hostilidade entre Burma Jones e Lana Lee aumenta.

\begin{tabular}{|c|c|}
\hline $\begin{array}{l}\text { "Take those glass off. How the hell can } \\
\text { you see all that crap on the floor?" }\end{array}$ & $\begin{array}{l}\text { "Tire esses óculos. Ô diabo! Como } \\
\text { é que você vai enxergar toda essa porcaria } \\
\text { no chão?" }\end{array}$ \\
\hline "Who wanna look at all that crap?" & $\begin{array}{l}\text { "Quem qué olhá pra toda essas } \\
\text { porcaria?" }\end{array}$ \\
\hline $\begin{array}{l}\text { "I told you to take the glasses off, } \\
\text { Jones." }\end{array}$ & $\begin{array}{l}\text { "Eu mandei você tirar os óculos, } \\
\text { Jones." }\end{array}$ \\
\hline $\begin{array}{l}\text { "The glasses stayin on." Jones } \\
\text { bumped the push broom into the bar stool. } \\
\text { "For twenty dollar a week, you ain running } \\
\text { a plantation here." }\end{array}$ & $\begin{array}{l}\text { "O óculos fica." Jones bateu com a } \\
\text { vassoura contra uma banqueta do bar. "Por } \\
\text { vinte dólar por semana, cê não tá } \\
\text { administrano nenhum fazendão aqui." }\end{array}$ \\
\hline $\begin{array}{l}\text { Lana Lee started snapping a rubber } \\
\text { band around the pile of bills and making } \\
\text { little piles of nickels that she was taking } \\
\text { out of the cash register. }\end{array}$ & $\begin{array}{l}\text { Lana Lee passou um elástico no maço } \\
\text { de notas e fez montinhos com as moedas } \\
\text { que retirara da caixa registradora. }\end{array}$ \\
\hline "Stop knocking that broom against the & "Pára de bater com essa vassoura no \\
\hline
\end{tabular}




\begin{tabular}{|c|c|}
\hline $\begin{array}{l}\text { bar," she screamed. "Goddamit to hell, you } \\
\text { making me nervous." }\end{array}$ & $\begin{array}{l}\text { balcão", gritou. "Desgraçado dos inferno, } \\
\text { cê tá me dano nos nervo." }\end{array}$ \\
\hline $\begin{array}{l}\text { "You want quiet sweeping, you get } \\
\text { you a old lady. I sweep yawng. }\end{array}$ & $\begin{array}{l}\text { "Cê qué varreção quieta, contrate } \\
\text { umavéia. Eu varro jovem." }\end{array}$ \\
\hline $\begin{array}{l}\text { The broom bumped against the bar } \\
\text { several more times. Then, the cloud of } \\
\text { smoke and the broom moved off across the } \\
\text { floor. }\end{array}$ & $\begin{array}{l}\text { A vassoura bateu contra o balcão } \\
\text { muitas outras vezes. Então a nuvem de } \\
\text { fumaça e a vassoura atravessaram o salão. }\end{array}$ \\
\hline $\begin{array}{l}\text { "You oughta tell your customer use } \\
\text { they ashtray, tell them peoples you workin } \\
\text { a man in here below the minimal wage. } \\
\text { Maybe they be a little considerate." }\end{array}$ & $\begin{array}{l}\text { "Cê deve falá pro seus cliente usá o } \\
\text { cinzeiro deles, fala pra'quelas pessoa que } \\
\text { aqui trabalha um homem por menos do } \\
\text { salário mínimo. Talvez eles tenha um } \\
\text { pouco de consideraçãos, tá ligado?” }\end{array}$ \\
\hline $\begin{array}{l}\text { "You better be glad I'm giving you a } \\
\text { chance, boy," Lana Lee said. "There's } \\
\text { plenty colored boys looking for work these } \\
\text { days." }\end{array}$ & $\begin{array}{l}\text { "É melhor você agradecer a } \\
\text { oportunidade que estou te dando, garoto", } \\
\text { disse Lana Lee "Tem muita gente de cor } \\
\text { procurando emprego hoje em dia." }\end{array}$ \\
\hline $\begin{array}{l}\text { "Yeah, and they's plenty color boy } \\
\text { turning vagran, too, when they see what } \\
\text { kinda wage peoples offerin. Sometime I } \\
\text { think if you color, it better to be a vagran." }\end{array}$ & $\begin{array}{l}\text { "É, e tem muitos de cor virano } \\
\text { vagabundo também, quando eles vê o tipo } \\
\text { de salário que'as pessoa oferta, tá ligado? } \\
\text { Às vez eu penso que se ocê é preto, é } \\
\text { melhor sê vagabundo." }\end{array}$ \\
\hline "You better be glad you're working." & $\begin{array}{l}\text { "É melhor você agradecer por estar } \\
\text { trabalhando." }\end{array}$ \\
\hline
\end{tabular}




\begin{tabular}{|c|c|}
\hline "Ever night I'm fallin on my knee." & "Todas noite eu caio de joelho." \\
\hline The broom bumped against a table. & A vassoura bateu contra uma mesa. \\
\hline $\begin{array}{l}\text { "Let me know when you finish with } \\
\text { that sweeping," Lana Lee said. "I got a } \\
\text { little errand I want you to run for me." }\end{array}$ & $\begin{array}{l}\text { "Me avisa quando você terminar com } \\
\text { essa vassoura", disse Lana Lee. "Eu tenho } \\
\text { um servicinho pra você fazer pra mim." }\end{array}$ \\
\hline $\begin{array}{l}\text { "Erran? Hey! I thought this a sweepin } \\
\text { and moppin job." Jones blew out a } \\
\text { cumulus formation. "What this erran shit?" }\end{array}$ & $\begin{array}{l}\text { "Servicinho?" Meu! Eu pensava que’o } \\
\text { meu trabalho era varrê e passá pano." } \\
\text { Jones assoprou uma nuvem em formação } \\
\text { de cúmulo. "Que merda de servicinho é } \\
\text { esse?" }\end{array}$ \\
\hline $\begin{array}{l}\text { "Listen here, Jones," Lana Lee dumped } \\
\text { a pile of nickels into the cash register and } \\
\text { wrote down a figure on a sheet of paper. } \\
\text { "All I gotta do is phone the police and } \\
\text { report you're out of work. You understand } \\
\text { me?" }\end{array}$ & $\begin{array}{l}\text { "Escuta aqui, Jones," Lana Lee } \\
\text { despejou uma pilha de moedas dentro da } \\
\text { caixa registradora e anotou um número } \\
\text { numa folha de papel. "Tudo que eu } \\
\text { preciso fazer é ligar pra polícia e informar } \\
\text { que você está desempregado. Dá pra } \\
\text { entender?" }\end{array}$ \\
\hline $\begin{array}{l}\text { "And I tell the po-lice the Night of Joy } \\
\text { a glorify cathouse. I fall in a trap when I } \\
\text { come to work in this place. Whoa! Now I } \\
\text { jus waitin to get some kinda evidence. } \\
\text { When I do, I really gonna flap my mouth } \\
\text { at the precinct." }\end{array}$ & $\begin{array}{l}\text { "E eu conto pra polícia que a Noite do } \\
\text { Prazê é um putêro melhorado. Eu caí numa } \\
\text { cilada quano eu vim trabalhá aqui. Ah- } \\
\text { hum! Agora eu só tô esperano alguma } \\
\text { prova. Assim que encontrá uma, eu vô } \\
\text { mesmo dá a fita lá na delegacia." }\end{array}$ \\
\hline
\end{tabular}




\begin{tabular}{|c|c|}
\hline "Watch your tongue." & "Veja como fala." \\
\hline $\begin{array}{l}\text { "Times changin," Jones said, adjusting } \\
\text { his sunglasses. "You cain scare color } \\
\text { peoples no more. I got me some people } \\
\text { form a human chain in front your door, } \\
\text { drive away your business, get you on TV } \\
\text { news. Color peoples took enough horseshit } \\
\text { already, and for twenty dollar a week you } \\
\text { ain piling no more on. I getting pretty tire } \\
\text { of bein vagran or working below the } \\
\text { minimal wage. Get somebody else run } \\
\text { your erran." }\end{array}$ & $\begin{array}{l}\text { "Os tempo são outro", disse Jones, } \\
\text { arrumando os óculos escuros. "Cê não } \\
\text { pode assustá as pessoa de cor mais não. } \\
\text { Conheço gente pra formá uma corrente } \\
\text { humana na frente da tua porta, espantá os } \\
\text { cliente, mostrá você na televisão. As } \\
\text { pessoa de cor já engoliram muita merda, e } \\
\text { por vinte dólar por semana cê não vai jogá } \\
\text { mais no monte, tá ligado? Eu tô cheio de } \\
\text { sê vagabundo ou de trabalhá por menos do } \\
\text { salário mínimo. Você que arrume outro } \\
\text { para fazê seu servicinho." }\end{array}$ \\
\hline $\begin{array}{l}\text { "Aw, knock it off and finish my floor. I'll } \\
\text { get Darlene to go." }\end{array}$ & $\begin{array}{l}\text { “Ah, dá um tempo e termine o meu } \\
\text { chão. Vou mandar a Darlene." }\end{array}$ \\
\hline $\begin{array}{l}\text { "That po gal." Jones explored a booth } \\
\text { with the broom. "Hustlin water, runnin } \\
\text { erran. Whoa!" }\end{array}$ & $\begin{array}{l}\text { "Aquela pobre coitada," Jones } \\
\text { explorou um reservado com a vassoura. } \\
\text { "Empurrá bebida aguada pra cima dos } \\
\text { cliente, fazê servicinho. Ah-hum!" }\end{array}$ \\
\hline $\begin{array}{l}\text { "Ring up the precinct about her. She's } \\
\text { a B-drinker." }\end{array}$ & $\begin{array}{l}\text { "Denuncie ela pra polícia. O trabalho } \\
\text { dela é fazer companhia pros clientes só pra } \\
\text { eles gastarem bastante em bebida (21)." }\end{array}$ \\
\hline "I waitin till I can ring up the precinct & "Tô esperano até eu podê denunciá \\
\hline
\end{tabular}




\begin{tabular}{|l|l|}
$\begin{array}{l}\text { about you. Darlene don wanna be a B- } \\
\text { drinker. She force to be a B-drinker. She A Darlene não quer ser uma garota } \\
\text { say she wanna go in show biz." }\end{array}$ & $\begin{array}{l}\text { vo bar. Ela é forçada a ser uma garota de } \\
\text { bar. Ela diz que qué entrá pro show biz." } \\
(22)\end{array}$ \\
$\begin{array}{l}\text { Yeah? Well, with the brains that girl's } \\
\text { got she's lucky they haven't shipped her } \\
\text { off to the funny farm." }\end{array}$ & $\begin{array}{l}\text { aquela menina tem, ela tem sorte de não ter } \\
\text { sido mandada pro hospício." }\end{array}$ \\
"She be better off there." & \\
(ACD, pp.82-83)
\end{tabular}

Notas

(21) B-drink é a mulher que fica no bar fazendo companhia aos clientes apenas para que eles gastem mais em bebidas. B-drinker, nesse caso, é o homem, a vítima. Tanto Lana Lee quanto Burma Jones empregam o termo errado, B-drinker. Como não há tradução em português para o termo, recorri à paráfrase.

(22) Por ser um termo que no Brasil usamos muito em inglês, mantive como está no texto de Toole, marcando igualmente a pronúncia incorreta. (ver nota 15)

\subsubsection{Burma Jones e Sr. Watson (1)}

No bar do senhor Watson, Jones relata ao amigo seu infortúnio de trabalhar na boate Noite do Prazer e recebe a sugestão de sabotar a patroa racista. 


\begin{tabular}{|c|c|}
\hline Jones e Mr. Watson & \\
\hline $\begin{array}{l}\text { "The problem come from not havin no } \\
\text { vocation skill, Jones was saying to Mr. } \\
\text { Watson. Jones was perched on a wooden } \\
\text { stool, his legs bent under him like ice } \\
\text { tongs ready to pick up the stool and boldly } \\
\text { carry it away before Mr. Watson's old } \\
\text { eyes. "If I had me some trainin I wouldn } \\
\text { be mopping no old whore flo." }\end{array}$ & $\begin{array}{l}\text { "O problema é eu não tê vocação pra } \\
\text { nada”, explicava Jones ao Sr. Watson. } \\
\text { Empoleirado num banco de madeira, as } \\
\text { pernas dobradas sob o assento como um } \\
\text { pegador de gelo pronto a pinçar o banco } \\
\text { sob os olhos cansados do Sr. Watson. "Se } \\
\text { eu fosse estudado, eu não taria passano } \\
\text { pano no chão de puta véia não, tá ligado?” }\end{array}$ \\
\hline $\begin{array}{l}\text { "Be good," Mr. Watson answered vaguely. } \\
\text { "Be well behave with the lady. }\end{array}$ & $\begin{array}{l}\text { "Num fala assim", respondeu o Sr. Watson } \\
\text { vagamente. "Si comporta com a dona." } \\
\text { (23) }\end{array}$ \\
\hline $\begin{array}{l}\text { "Wha? Ooo-wee. You don understan at all, } \\
\text { man. I got a job workin with a bird. How } \\
\text { you like workin with a bird?" Jones aimed } \\
\text { some smoke over the bar. "I mean, I'm } \\
\text { glad that girl gettin a chance. She been } \\
\text { workin for that Lee mother a long time. } \\
\text { She need a break. But I bet that bird be } \\
\text { makin more money than me. Whoa!" }\end{array}$ & $\begin{array}{l}\text { “Quê? Ôxe! Cê num entende nada, mano. } \\
\text { Eu tô trabalhano cum passarinho. Se ia } \\
\text { gostá de trabalhá cum passarinho?” Jones } \\
\text { lançou fumaça sobre o balcão. “Acho da } \\
\text { hora a moça tê uma chance. Ela trabalha } \\
\text { pra aquela vaca (24) da Lee faz tempo, tá } \\
\text { ligado? Ela precisa de um breique (25). } \\
\text { Mas eu aposto que aquele passarinho tá } \\
\text { ganhano mais dinheiro que eu. Ah-hum! }\end{array}$ \\
\hline & "Seje bonzinho, Jones." \\
\hline $\begin{array}{l}\text { "Whoa! Hey, you really been brainwash," } \\
\text { Jones said. "You ain got nobody to come } \\
\text { in and mop your flo. How come? Tell me }\end{array}$ & $\begin{array}{l}\text { "Ah-hum! Eles fez mesmo uma lavage } \\
\text { cerebral no cê”, disse Jones. "Cê não tem } \\
\text { ninguém passano pano no teu chão. Por } \\
\text { quê? Diz aí." }\end{array}$ \\
\hline
\end{tabular}




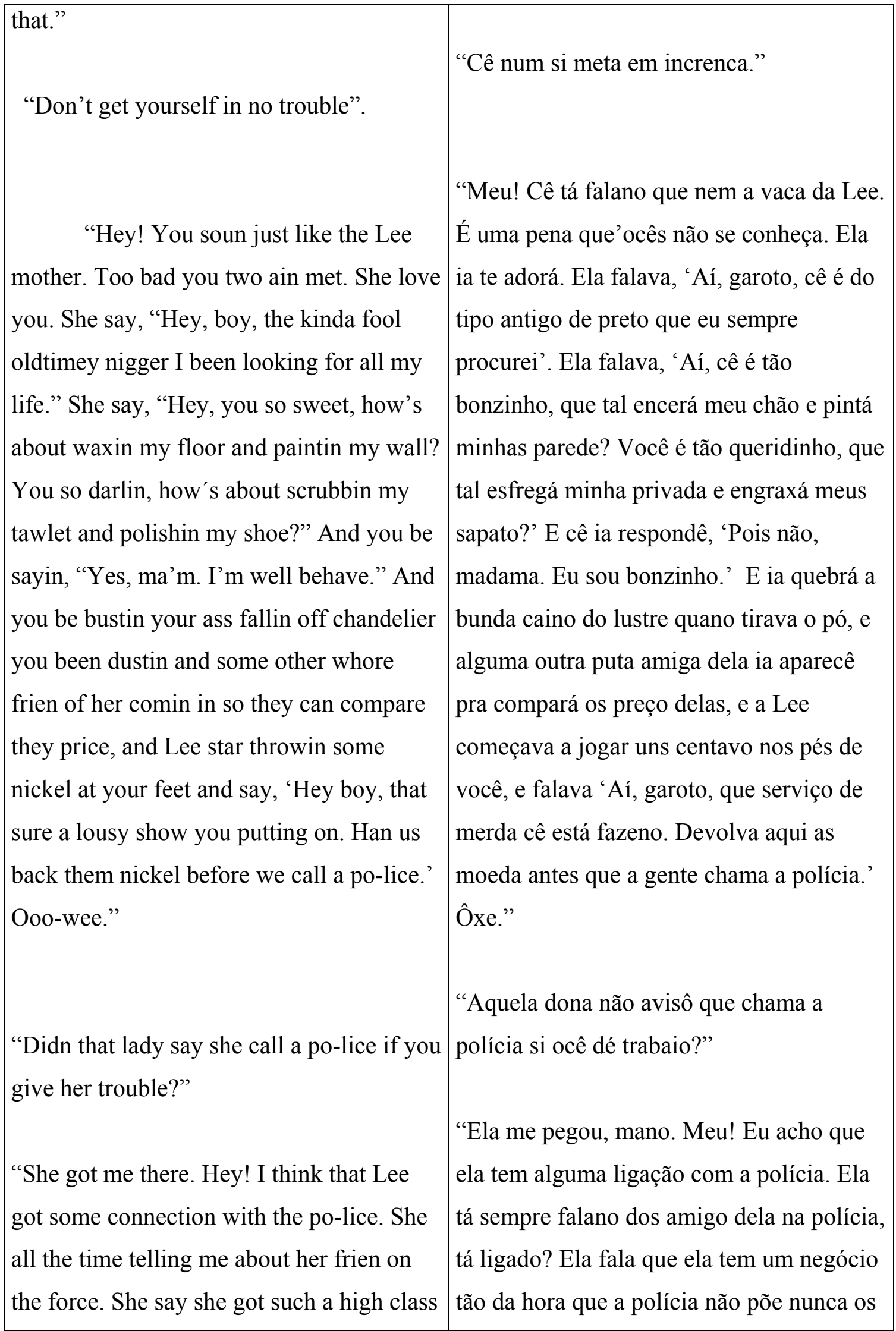




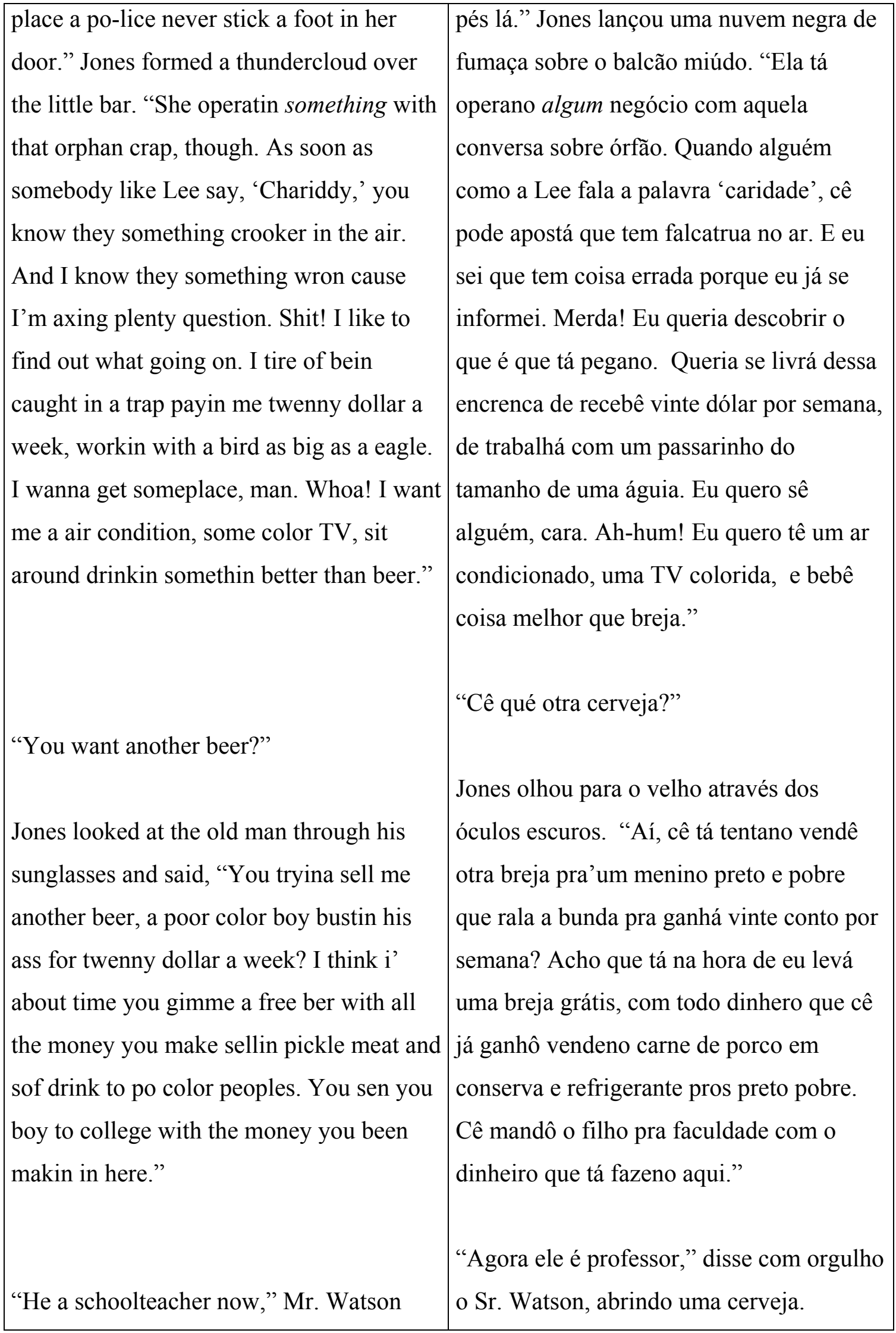




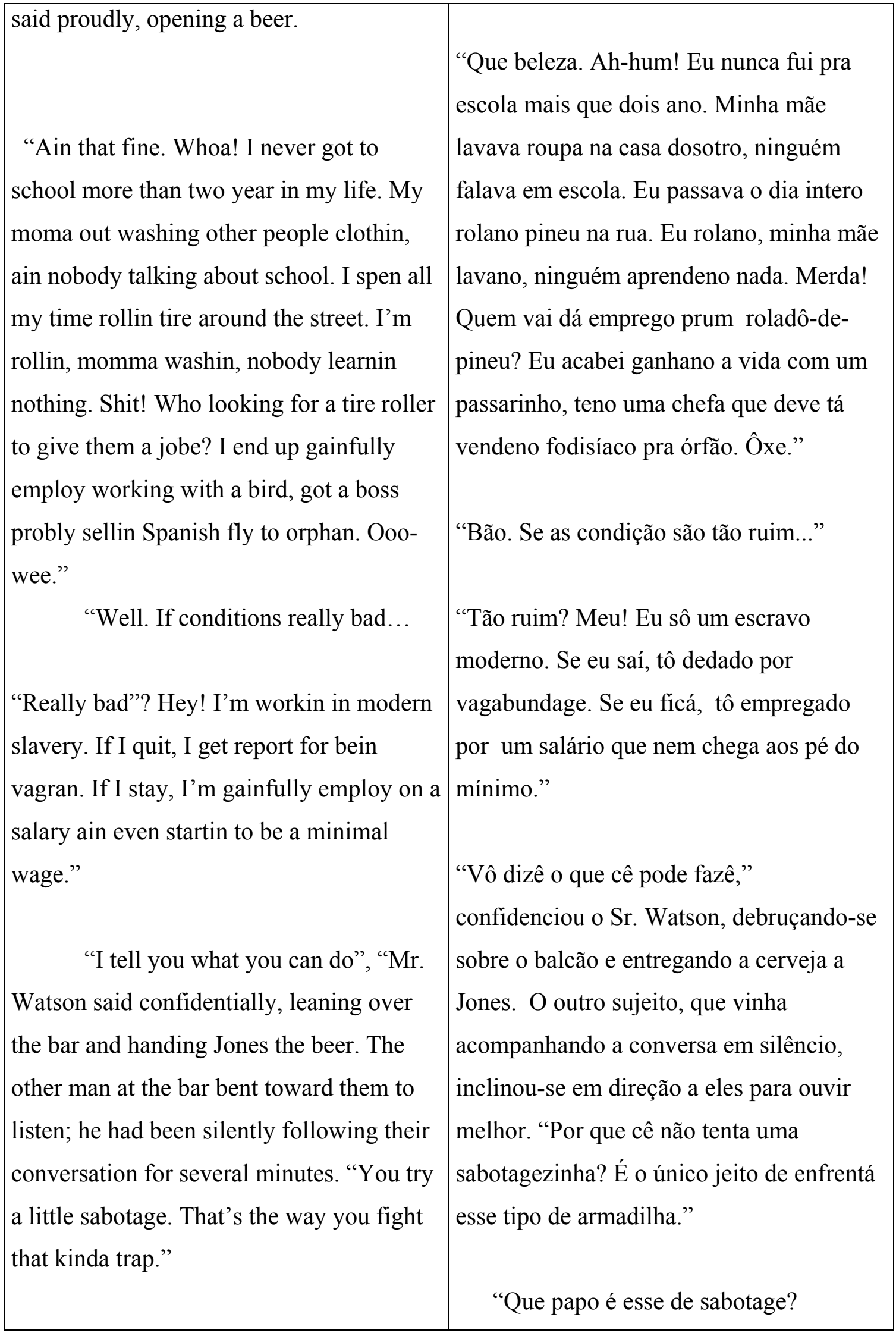




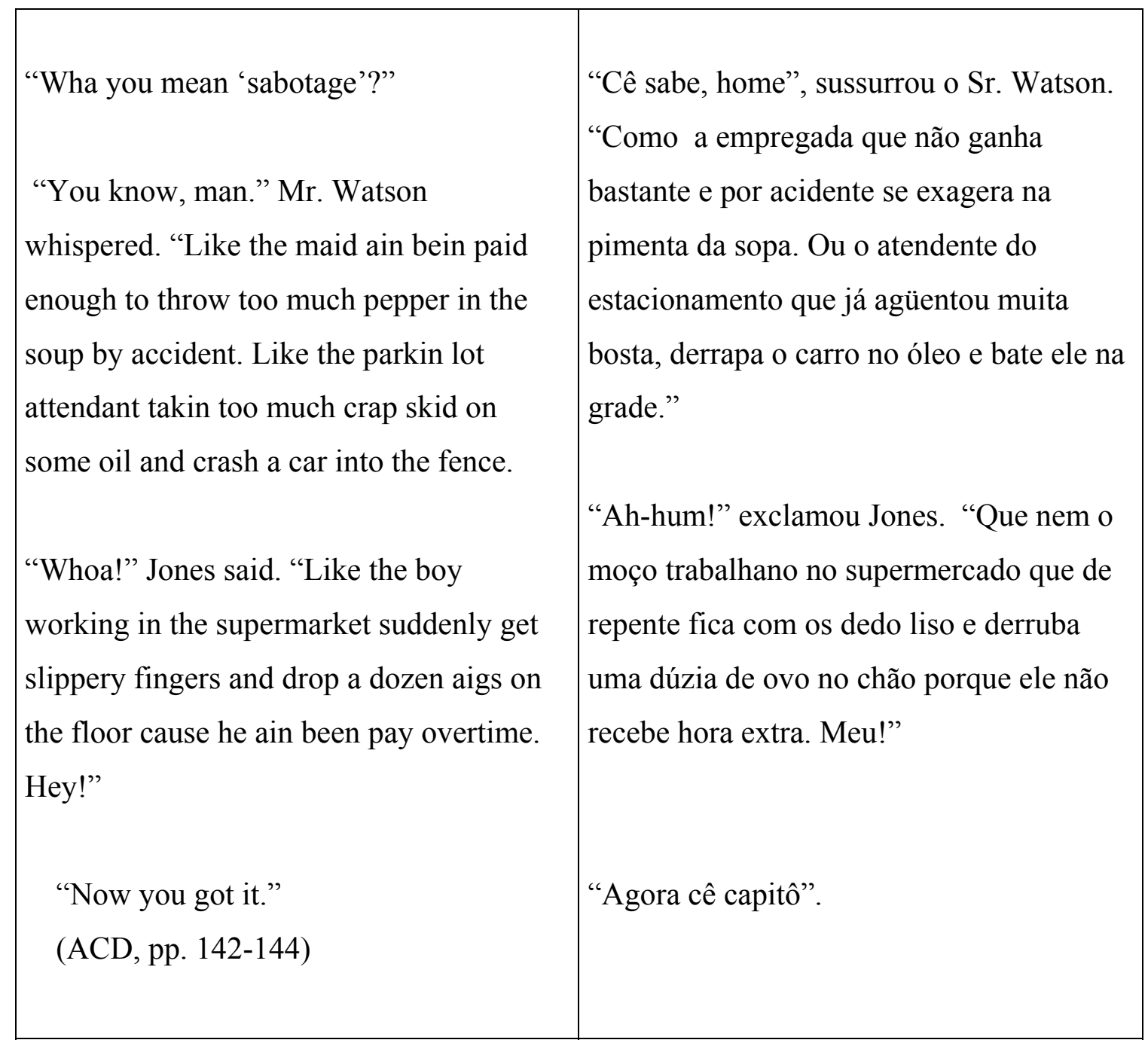

Notas

(23) O senhor Watson também apresenta um falar bem carregado em marcadores dialetais, o que optei por manter na tradução, empregando elementos que lhe conferissem um certo tom acaipirado.

(24) Neste contexto "mother" é traduzido por "vaca". 
(25) Ver nota 15.

\subsubsection{Burma Jones e Ignatius}

Numa noite em que está empurrando o carrinho de cachorro-quente pelo Bairro Francês, ainda vestido em seu uniforme de pirata, Ignatius se aproxima da Boate Noite do Prazer à procura da mulher que ele vira na figurinha pornográfica lendo $A$ Consolação da Filosofia. Jones reconhece o gordo maluco e dá início ao seu plano de sabotagem contra a patroa ao sugerir a Ignatius que venha assistir ao show da dançarina exótica "Harla O'Horror" logo mais à noite.

\begin{tabular}{|c|c|}
\hline $\begin{array}{l}\text { "How come a white cat like you, } \\
\text { talking so good, sellin weenies?" }\end{array}$ & $\begin{array}{l}\text { "Como é que pode um cara branco que } \\
\text { nem você, falano tão bem, vendeno } \\
\text { cachorro-quente? }\end{array}$ \\
\hline $\begin{array}{l}\text { "Please blow you smoke elsewhere. } \\
\text { My respiratory system, unfortunately, is } \\
\text { below par. I suspect that I am a result of a } \\
\text { particularly weak conception on the part of } \\
\text { my father. His sperm was probably emitted } \\
\text { in a rather offhand manner." }\end{array}$ & $\begin{array}{l}\text { "Por favor, sopre a fumaça do cigarro } \\
\text { em outra direção. Infelizmente, meu } \\
\text { sistema respiratório funciona abaixo do } \\
\text { normal. Eu desconfio que sou o resultado } \\
\text { de uma concepção particularmente débil } \\
\text { da parte de meu pai. Seus espermatozóides } \\
\text { provavelmente foram emitidos de forma } \\
\text { bastante precipitada." (26) }\end{array}$ \\
\hline $\begin{array}{l}\text { This was luck, Jones thought. The fat } \\
\text { mother dropped out of the sky just when } \\
\text { he needed him most. }\end{array}$ & $\begin{array}{l}\text { Que sorte, pensou Jones. A bicha } \\
\text { gorda (27) caíra do céu bem quando ele } \\
\text { mais precisava dela. }\end{array}$ \\
\hline
\end{tabular}


"You mus be outa your min man. You oughta have you a good job, big Buick, all that shit. Whoa! Air condition, color TV..."

"I have a very pleasant occupation," Ignatius answered icily. "Outdoor work, no supervision. The only pressure is on the feet."

"If I go to college I wouldn be draggin no meat wagon aroun sellin peoples a lotta garbage and shit."

"Please! Paradise products are of the highest quality." Ignatius rapped his cutlass against the curb. "Anyone employed by that dubious bar is not in position to question another's occupation."

"Shit, you think I like the Night of Joy? Ooo-wee. I wanna get someplace. I like to get someplace good, be gainfully employ, make me a living wage.
“Cê deve tá me zoano, mano. Cê pode arranjá um emprego bão, um carrmão, toda essas merda. Ah-hum! Ar-condicionado, TV colorida..."

"Eu tenho uma ocupação deveras aprazível", respondeu Ignatius friamente. “Trabalho ao ar livre, sem supervisão. A única pressão recai sobre os pés."

“Se eu tinha faculdade, eu não ia ficá arrastano nenhum carrinho de lanche não, vendeno um monte de porcaria, tá ligado?"

“Por favor! Os produtos Paraíso são da melhor qualidade." Ignatius golpeou o meio-fio com o cutelo de pirata. "Qualquer um que trabalhe naquele bar duvidoso não está em posição de questionar a ocupação de outra pessoa."

"Porra! Cê acha que eu gosto da Noite do Prazê? Ôxe. Eu quero subi na vida. Eu quero tê uma boa posição, sê registrado, ganhá um salário que dê pra vivê. 


\begin{tabular}{|c|c|}
\hline $\begin{array}{l}\text { "Just as I suspected," Ignatius said } \\
\text { angrily. "In other words, you wan to } \\
\text { become totally bourgeois. You people } \\
\text { have all been brainwashed. I imagine that } \\
\text { you'd like to become a success or } \\
\text { something equally vile." }\end{array}$ & $\begin{array}{l}\text { "Exatamente como eu suspeitava", } \\
\text { disse Ignatius. "Em outras palavras, você } \\
\text { deseja tornar-se um verdadeiro burguês. } \\
\text { Vocês todos passaram por uma lavagem } \\
\text { cerebral. Imagino que você gostaria de } \\
\text { alcançar o sucesso ou algo igualmente } \\
\text { abjeto." }\end{array}$ \\
\hline "Hey, now you gettin me. Whoa! & $\begin{array}{l}\text { "Aí, agora cê tá me ofendeno. Ah- } \\
\text { hum!" }\end{array}$ \\
\hline $\begin{array}{l}\text { "I really don't have the time to discuss } \\
\text { the errors of your value judgments. } \\
\text { However, I would like some information } \\
\text { from you. Do you by any chance have a } \\
\text { woman in that den who is given to } \\
\text { reading?" }\end{array}$ & $\begin{array}{l}\text { "Eu realmente não tenho tempo para } \\
\text { discutir os erros de seus julgamentos de } \\
\text { valor. Todavia, eu desejaria algumas } \\
\text { informações. Por um acaso você conhece } \\
\text { alguma mulher naquele covil que seja dada } \\
\text { à leitura?" }\end{array}$ \\
\hline $\begin{array}{l}\text { "Yeah. She all the time slippin me } \\
\text { somethin to read, tellin me I be improvin } \\
\text { myself. She pretty decent." }\end{array}$ & $\begin{array}{l}\text { “Ah, conheço. Ela o tempo todo me } \\
\text { passa alguma coisa pra lê, falano que eu vô } \\
\text { se melhorá. Ela é mó decente, tá ligado?" }\end{array}$ \\
\hline $\begin{array}{l}\text { "Oh, my God." The blue and yellow } \\
\text { eyes flashed. "Is there any away that I can } \\
\text { meet this paragon?" }\end{array}$ & $\begin{array}{l}\text { "Ah, meu Deus". Os olhos azuis } \\
\text { amarelados faiscaram. "Há alguma } \\
\text { maneira pela qual eu possa conhecer esse } \\
\text { modelo de perfeição?" }\end{array}$ \\
\hline
\end{tabular}




\begin{tabular}{|c|c|}
\hline $\begin{array}{l}\text { Jones wondered what this was all } \\
\text { about. He said, "Whoa! You wanna see } \\
\text { her, you come around some night, see her } \\
\text { dancin with her pet." }\end{array}$ & $\begin{array}{l}\text { Jones queria saber do que se tratava. } \\
\text { "Ah-hum! Se quisé vê ela, volte uma noite, } \\
\text { ela dança com o animal de estimação } \\
\text { dela." }\end{array}$ \\
\hline $\begin{array}{l}\text { "Good grief. Don't tell me that she is } \\
\text { this Harlett O'Hara." }\end{array}$ & $\begin{array}{l}\text { "Minha nossa! Não me conte que ela é } \\
\text { a tal Harlett O'Hara?" }\end{array}$ \\
\hline $\begin{array}{l}\text { "Yeah. She Harla O’Horror all right." } \\
\text { (ACD, pp. 306-308) }\end{array}$ & $\begin{array}{l}\text { "É. Ela é a Harla O’Horror em } \\
\text { pessoa." }\end{array}$ \\
\hline
\end{tabular}

Notas

(26) Busquei manter o registro elevado da fala de Ignatius.

(27) Numa leitura mais ousada, optei traduzir "fat mother" por "bicha gorda".

Ignatius retorna à boate e chega o momento de Burma Jones sabotar Lana Lee. É a noite de estréia da desajeitada dançarina Darlene, que, seguindo ordens de Lee, apresenta um número em que está vestida num traje de baile do período da Guerra Civil americana. Harlett O'Hara, numa alusão a Scarlett O'Hara, de Gonne with the Wind, é uma donzela recatada que será despida no palco pelo passarinho que Jones tanto odeia.

\begin{tabular}{|c|c|}
\hline $\begin{array}{l}\text { As he crossed onto the Night of Joy } \\
\text { block, he heard the doped Negro calling, } \\
\text { "Whoa! Come in, see Miss Harla O'Horror } \\
\text { dancin with her pet. Guarantee one hunner } \\
\text { percent real plantation dancing. Ever }\end{array}$ & $\begin{array}{l}\text { Ao atravessar a rua em direção à } \\
\text { boate Noite do Prazer, ele ouviu o negro } \\
\text { gritando: “Ah-hum! Chega aí, venham } \\
\text { ver a senhorita Harla O'Horror dançano } \\
\text { com o bichinho de estimação dela. É }\end{array}$ \\
\hline
\end{tabular}


motherfuckin drink got a guarantee knockout drop. Whoa! Everybody guarantee to catch them some clap off they glass. Hey! Nobody never see nothin like Miss Harla O'Horror Old South pet dancin. Openin night tonight, maybe this be your one and only chance to catch this act. Ooo-wee."

Ignatius saw him trough the crowd that was hurrying past the Night of Joy.

Apparently no one was heeding the barker's plea. The barker himself had paused in his calling to emit a nimbus formation of smoke. He was wearing tails and a stovepipe hat that rested at an angle above his dark glasses, smiling through the smoke at the people who resisted his appeals.

"Hey! All you peoples draggin along here. Stop and come stick your ass on Night of Joy stool," he started again. "Night of Joy got genuine color peoples workin bellow the minimal wage. Whoa! Guarantee plantation atmosphere, got cotton growin right on the stage right in front your eyeball, got a civil garantido cem por cento baile no estilo casa-grande de verdade. Cada gole é uma perna mole. Ah-hum! Os aplauso vale o dinheiro de cada copo. Meu! Ninguém nunca viu nada como a dança do passarinho do Velho Sul da senhorita Harla O'Horror. Estréia esta noite. Talvez esta seja a sua única chance de ver o número. Ôxe."

Ignatius viu-o através da multidão que passava apressada em frente à Noite do Prazer.

As pessoas passavam como que sem atender ao apelo do chamador (28). O próprio chamador havia se calado para lançar uma formação nimbo de fumaça. Jones, vestido de casaca e cartola muito alta, que fazia um ângulo com os óculos escuros, sorria para as pessoas que resistiam aos seus apelos em meio à fumaça.

"Meu! Cêis aí passano aqui em frente. Entra e senta a bunda nos mocho da Noite do Prazê," recomeçou ele. "A Noite do Prazê oferece genuínas pessoa de cor trabalhano abaixo do salário mínimo. Ahhum! Clima de fazenda garantido, com algodão cresceno bem no palco, bem na 


\begin{tabular}{|c|c|}
\hline $\begin{array}{l}\text { right worker getting his ass beat up between } \\
\text { show. Hey!" }\end{array}$ & $\begin{array}{l}\text { frente da suas pupila . Tem ativista dos } \\
\text { direito civil apanhano nos intervalo. Meu! }\end{array}$ \\
\hline $\begin{array}{l}\text { “Is Miss O'Hara on yet?” Ignatius } \\
\text { slobbered at the barker's elbow. }\end{array}$ & $\begin{array}{l}\text { "A senhorita O'Hara já estreou? Ignatius } \\
\text { babou no cotovelo do chamador. }\end{array}$ \\
\hline $\begin{array}{l}\text { "Ooo-wee!" The fat mother had arrived. } \\
\text { In person. "Hey, man, how come you still } \\
\text { warin that earrin and scarve? What you } \\
\text { suppose to be anyway?" }\end{array}$ & $\begin{array}{l}\text { "Ôxe!" A bicha gorda chegara. Em } \\
\text { pessoa. “Aí, mano, por que cê ainda tá de } \\
\text { brinco e cachecol? Cê tá fantasiado do } \\
\text { quê, afinal?" }\end{array}$ \\
\hline $\begin{array}{l}\text { "Please." Ignatius rattled his cutlass a bit. } \\
\text { "I haven't time to chat. I have no success } \\
\text { pointers for you tonight, I'm afraid. Has } \\
\text { Miss O'Hara begun?" }\end{array}$ & $\begin{array}{l}\text { "Por favor." Ignatius balançou o } \\
\text { cutelo. "Eu não tenho tempo para } \\
\text { conversar. Eu não vou lhe mostrar o } \\
\text { caminho do sucesso esta noite. Sinto } \\
\text { muito. A senhorita O'Hara já começou?" }\end{array}$ \\
\hline $\begin{array}{l}\text { "She be startin in a few minute. You } \\
\text { better get your ass in there and get you a } \\
\text { ringside seat. I talk to the head waiter, he say } \\
\text { he have a table all reserve for you." }\end{array}$ & $\begin{array}{l}\text { “Ela vai tá começano em alguns } \\
\text { minuto. É melhor cê mexê essa bunda } \\
\text { gorda e conseguir um lugar na primeira } \\
\text { fileira. Eu falei com o garçom e ele disse } \\
\text { que tem uma mesa reservada pro'cê." }\end{array}$ \\
\hline $\begin{array}{l}\text { "Is that true?" Ignatius asked eagerly. "The } \\
\text { Nazi proprietress is gone, I hope." }\end{array}$ & $\begin{array}{l}\text { "Verdade?" perguntou Ignatius afoito. } \\
\text { “A proprietária nazista já partiu, eu } \\
\text { imagino." }\end{array}$ \\
\hline $\begin{array}{l}\text { "She jet away to California this afternoon, } \\
\text { say Harla O'Horror so good she gonna go } \\
\text { dip her ass in the ocean a while and stop } \\
\text { worryin about her club." }\end{array}$ & $\begin{array}{l}\text { "Ela voô pra Califórnia hoje de tarde, tá } \\
\text { ligado? Ela falô que a Harla O’Horror é tão } \\
\text { boa que ela ia se molhá a bunda no oceano } \\
\text { um pouquinho e pará de se preocupa co’a } \\
\text { boate.” }\end{array}$ \\
\hline
\end{tabular}




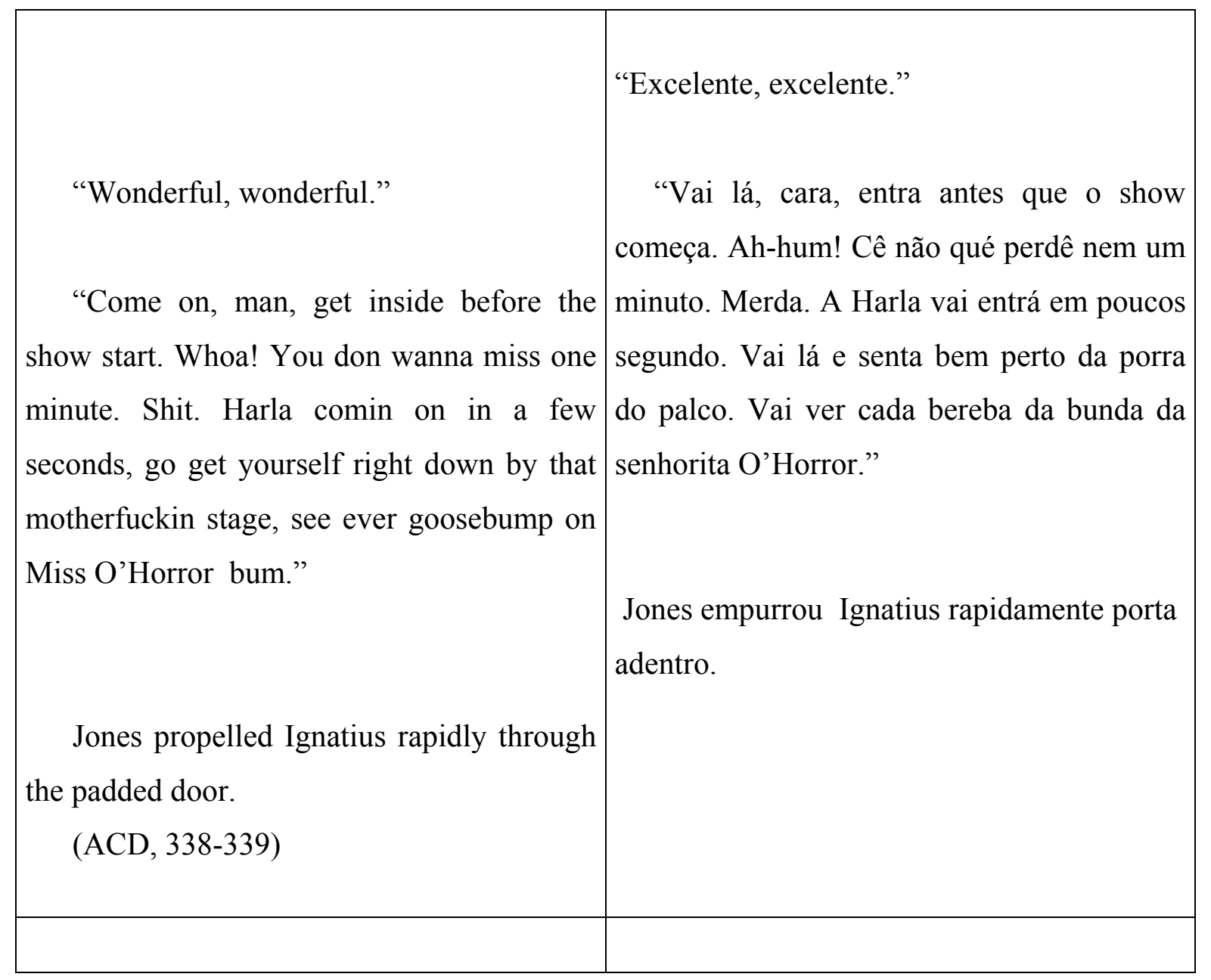

Notas

(29) “Chamador", modo popular de designar a função daqueles que ficam nas portas das lojas anunciando as promoções.

\subsubsection{Burma Jones e Mr. Watson (2)}

Na última participação de Jones no romance, ele relata ao Sr. Watson a bem-sucedida sabotagem na boate Noite do Prazer. O jovem mostra-se melancólico, pois agora está novamente desempregado.

\begin{tabular}{|r|rr|}
\hline $\begin{array}{r}\text { Jones spread the newspaper on the bar } \\
\text { of Mattie's Ramble Inn and blew out some }\end{array}$ & bar $\quad$ Mattie's Ramble e lançou fumaça \\
\hline
\end{tabular}




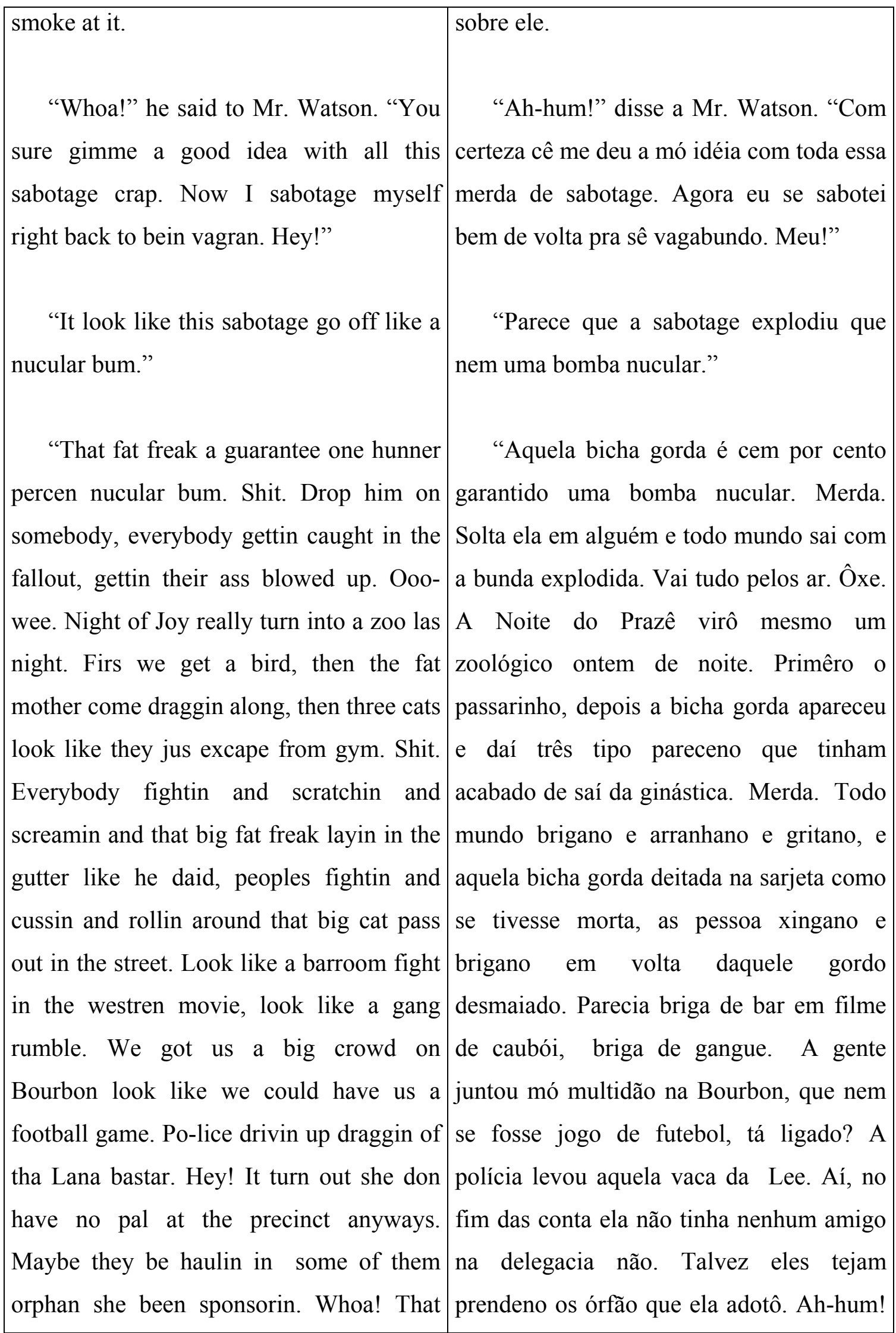




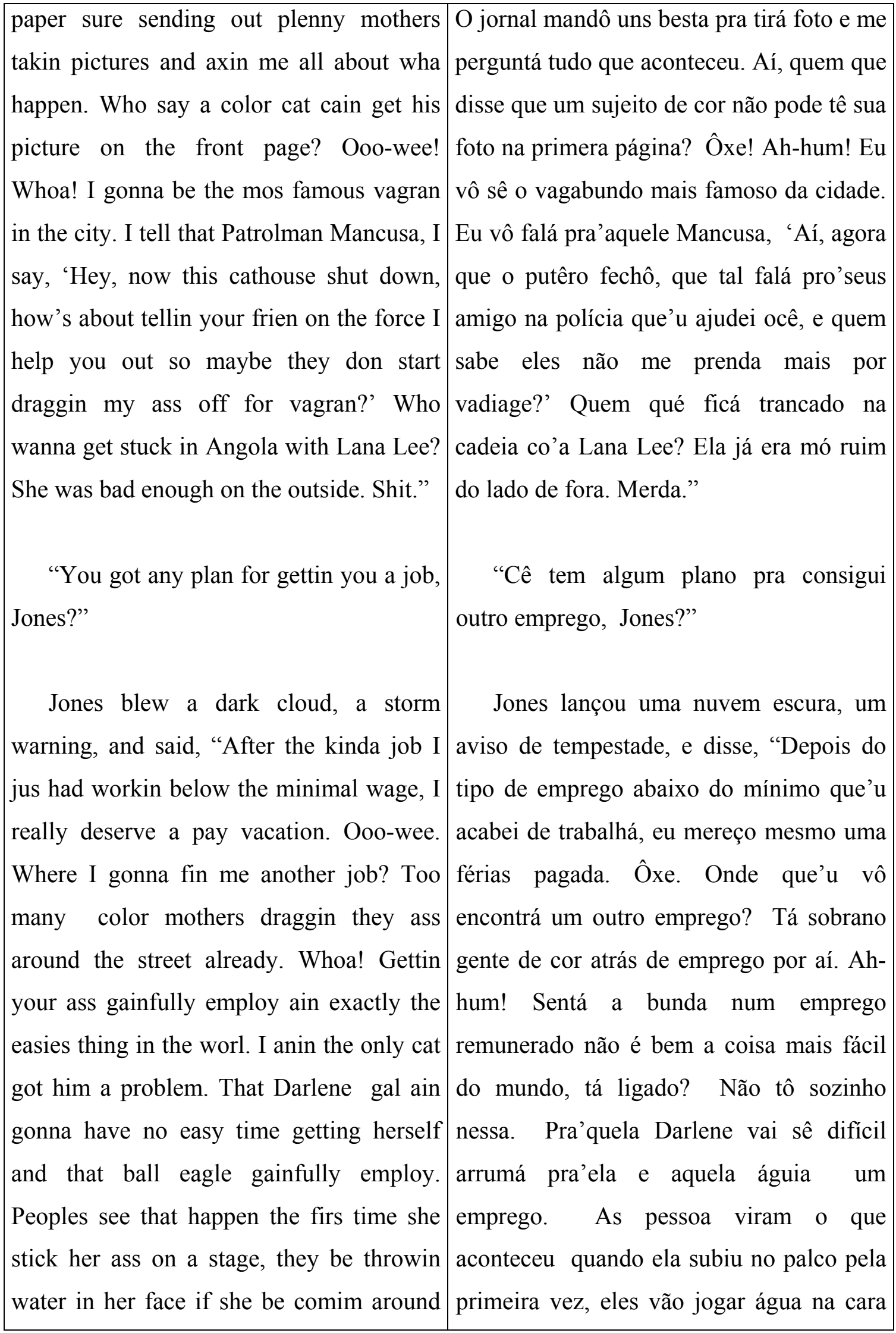




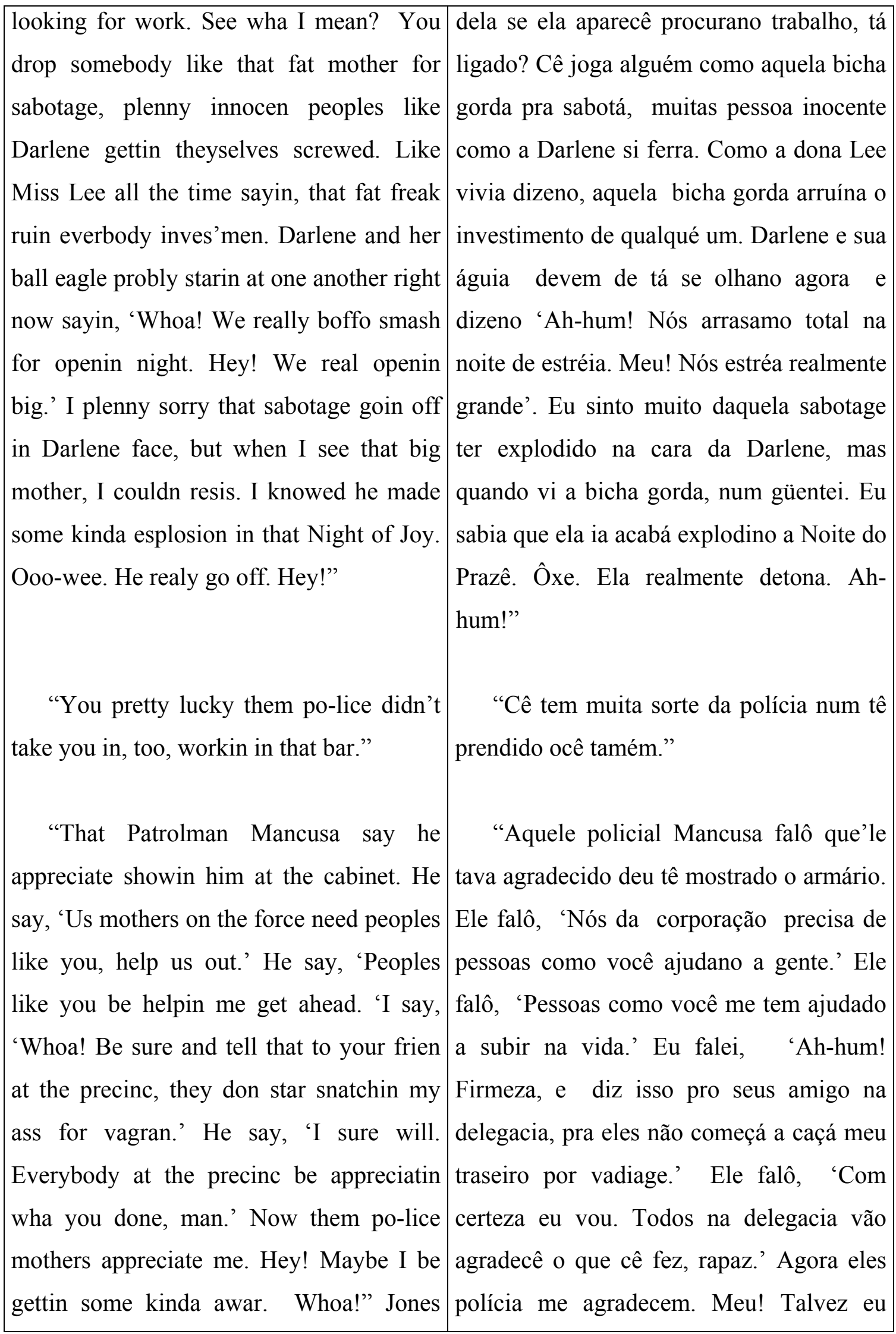




\begin{tabular}{|c|c|}
\hline $\begin{array}{l}\text { aimed some smoke over Mr. Watson's tan } \\
\text { head. "That Lee bastar really got her some } \\
\text { snapshot of herself in the cabinet. } \\
\text { Patrolman Mancusa starin at them pictures, } \\
\text { his eyeballs about to fall out on the floor. } \\
\text { He sayin, 'Whoa! Hey! Wow!' He sayin, } \\
\text { 'Boy, I really be gettin ahead now." I say } \\
\text { to myself, 'Maybe some peoples be gettin } \\
\text { ahead. Some other peoples be turning } \\
\text { vagran again. Some peoples ain gonna be } \\
\text { gainfully employ below the minimal wage } \\
\text { after tonight. Some peoples be draggin } \\
\text { they ass all around town somewheres, be } \\
\text { buyin me air condition, color TV'. Shit. } \\
\text { Firs I 'm a glorify broom expert, now I'm } \\
\text { vagran." }\end{array}$ & $\begin{array}{l}\text { receba algum tipo de recompensa. Ah- } \\
\text { hum!" Jones mirou fumaça sobre a cabeça } \\
\text { bronzeada de Mr. Watson. "Aquela biscate } \\
\text { da Lee tinha mesmo umas foto dela no } \\
\text { armário. O guarda Mancusa vidrou } \\
\text { naquelas foto, as pupila quase caino no } \\
\text { chão. Ele falava, 'Ah-hum! Meu! Uaus!' } \\
\text { Ele falava, 'Garoto, agora eu vou mesmo } \\
\text { pra frente.' Eu pensei comigo, 'Talvez } \\
\text { algumas pessoa vão subir na vida. Outras } \\
\text { pessoa vão torná vagabundo de novo. } \\
\text { Algumas pessoa não vai tê mais trabalho } \\
\text { abaixo do salário mínimo depois dessa } \\
\text { noite. Algumas pessoa iam rodá o traseiro } \\
\text { por toda a cidade por aí, tá se comprano } \\
\text { um ar-condicionado, televisão colorida.' } \\
\text { Merda. Primêro eu sô uma autoridade em } \\
\text { vassôra cheio das glória, agora eu sô } \\
\text { vagabundo." }\end{array}$ \\
\hline
\end{tabular}




\section{CONCLUSÃO}

Numa autocrítica à estratégia discursiva pela qual optei, é preciso lembrar que minhas escolhas expõem o fato de eu não pertencer ao grupo social retratado: mesmo que eu tenha "a melhor das intenções" nessa escolha, fica evidente que, enquanto leitora e reprodutora dessa visão na tradução, vi nos jovens da periferia e sua linguagem um Outro cultural diverso do meu, e dele, de certa forma, pela própria diferença, fui capaz de extrair humor. Por outro lado, o personagem de Burma causou-me, logo de início, uma forte empatia, e quanto mais eu ria de seu modo de falar, mais eu admirava o personagem. Espero que minha tradução cause a mesma reação nos leitores.

$\mathrm{Na}$ construção do dialeto literário de Burma Jones, as gírias cumpriram com o papel de melhor associá-lo à fala do grupo social dos jovens das periferias. A decisão parece acertada na análise de Preti, ao autor salientar que o elemento gírio, "com seu humor, sua ironia, seu poder agressivo, (quando não injurioso), cumpre, também, o papel de um verdadeiro processo de catarse, de purgação para o homem moderno, que nele encontra uma das formas de defender-se das injustiças sociais atacando-as no conservadorismo de sua linguagem" (Preti, 2004, p. 70). No entanto, os desvios fonéticos e morfológicos que aparecem na tradução ligam-se não apenas a essa comunidade, pois muitas dessas características são consideradas tanto da língua falada em geral como da raça negra, como pude verificar no trabalho de Mendonça sobre a influência dos africanos no português do Brasil.

Apesar da excelente tradução de Cristina Boselli para A Confederacy of Dunces, considerando-se o total da obra, a linguagem de Burma Jones está marcada apenas em registro 
coloquial e pontuada por tabuísmos, o que não caracteriza o personagem em seu aspecto sociocultual, principalmente quanto à etnia. Infelizmente não foi possível localizar a tradutora para saber quais as restrições (se houve) impostas pela editora nesse processo. Na tradução de Boselli a linguagem é bem reservada se comparada à proposta apresentada neste estudo, em especial no aspecto gramatical, em que a tradutora respeita, por exemplo, normas de concordância e de posição dos pronomes. O resultado é ambíguo, como verificado no trecho em que Burma Jones vai à boate Noite do Prazer:

- Vim por causa do anúncio de faxineiro que saiu no jornal.

- É? - Lana Lee olhou para os óculos escuros. - Tem referências?

- A polícia pode lhe dar referências. Disseram que é melhor eu sentar o rabo num emprego garantido - disse Jones, e soprou um jato de fumaça dentro do bar vazio.

- Sinto muito. Nada de tipos da polícia. Não num negócio como esse. Tenho que zelar pelo meu investimento.

- Eu ainda não sou bem um desses tipos, mas sei dizer que aquele ordinário não vai ter como continuar com a queixa contra mim. Foi o que eles me disseram.

(Toole, s/d, p. 41)

A timidez da tradução de Boselli, e de outras traduções de personagens negros (Milton, 2002, pp. 54-57), não me parece justificável enquanto ausência de possibilidade expressiva da língua portuguesa, nem de exemplos na literatura brasileira. Como demonstrado no Capítulo II, há vários exemplos aos quais os tradutores podem recorrer na busca de soluções criativas para a elaboração do dialeto literário desses personagens. Há mesmo traduções em que encontramos 
essa diferenciação e que são fonte de pesquisa, como $O$ som e a fúria, de William Faulkner, vertido para o português por Paulo Henriques Britto ${ }^{6}$.

${ }^{6}$ Editora Cosac \& Naify, 2004. 


\section{REFERÊNCIAS BIBLIOGRÁFICAS}

ARROJO, R. Oficina de tradução. São Paulo: Ática, 1992.

ANDRADE, Mário. Foi Sonho. In: Os Melhores Contos - Mário de Andrade. LOPEZ, Telê Ancona (Org.). São Paulo, Global Editora, 1997.

AZEVEDO, Milton M.. Vozes em Branco e Preto. São Paulo: Edusp, 2003.

BERMAN, Antoine. A prova do Estrangeiro. Bauru: EDUSC, 2002.

CODRESCU, Andrei. 'A Confederacy of Dunces', Making the Natives Wince. In:

Chronicle of Higher Education, v. 46, n. 32, p. b7, 2000.

DAIGREPONT, Lloyd. Ignatius Reilly and The Confederacy of Dunces. New Orleans Review, New Orleans, v. 9 (3), p. 74-80, Winter, 1982.

FENNELL, Barbara; BENNETT, John. Sociolinguistic Concepts and Literary Analysis. In: American Speech: A Quarterly of Linguistic Usage, S.1., v.66, n.4, p. 371-79, Winter, 1991.

FERRÉZ. Manual Prático do Ódio. Rio de Janeiro: Objetiva, 2003.

. Capão Pecado. 2.ed. São Paulo: Labortexto Editorial, 2000.

FILHO, João. Encarniçado. São Paulo: Baleia, 2004.

FREIRE, Marcelino. Contos Negreiros. Rio de Janeiro: Record, 2005.

IVES, Sumner. A Theory of Literary Dialect. Tulane studies in English, New Orleans, v. 2, p. 137-82, 1950.

KLINE, Michael. Narrating the Grotesque: The Rhetoric of Humor in John Kennedy Toole's A Confederacy of Dunces. Southern Quarterly: A Journal of Arts in the South, S.1., v. 37, n. 3-4, p. 283-91, Spring-Summer, 1999.

LABOV, William. Contraction, deletion and inherent variability of the English copula. In: . Language in the Inner City: Studies in the Black English Vernacular. Philadelphia:

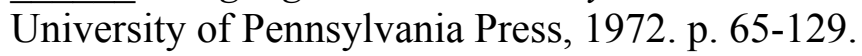

LANE-MERCIER, G. Translating the untranslatable: the translator's aesthetic, ideological and political responsibility. Target, Amsterdam, v. 9, n. 1, p. 43-68, 1997.

43-62, feb., 1990.

. Pour une analyse du dialogue romanesque. In: Poetique, Seuil, n. 81-84, p. 
LAVOIE, Judith. Problèmes de traduction du vernaculaire noir américain: le cas de The Adventures of Huckleberry Finn. In: TTR, S.1. v. 7, n. 2, 1994.

MARTINS, Nilce Sant'anna. Introdução à estilística. São Paulo: T.A. Queiroz, Editor, 2000 .

MAcKETHAN, Lucinda H., Redeeming Blackness: Urban Allegories of O'Connor, Percy, and Toole. Studies in Literary Imagination, S.1., v. 27, n.2, p. 29-39, Fall, 1994.

McNEIL, David. A Confederacy of Dunces as Reverse Satire: The American Subgenre. Mississippi Quarterly: The Journal of Southern Culture, S.1., v. 38, n.1, p. 33-47, Winter, 1984-1985.

MENDONÇA, Renato. A Influência Africana no Português do Brasil. 4.ed. Rio de Janeiro: MEC/Civilização Brasileira, 1973.

MILTON, John. O clube do livro e a tradução. Bauru: EDUSC, 2002.

MINNICK, Lisa Cohen. Dialect and Dichotomy. Literary Representation of African American Speech. Tuscaloosa: The University of Alabama Press, 2004.

MORENO, Silene; OLIVEIRA, Paulo. Da Servilidade da Tradução Subversiva: Servir a Quem, Por Quê? Alfa: Revista de Lingüística, Universidade Estadual Paulista, v.44, n. esp, p. 131-155. São Paulo, 2000.

NETO, Coelho. Rei negro: romance barbaro. 2.ed. Porto: Livraria Chardon, 1926.

NEVILS, René P.; HARDY, Deborah. Ignatius Rising. Baton Rouge: Louisiana State University Press, 2001.

NOMURA, MASA. Linguagem Funcional e Literatura. Presença do Cotidiano no Texto Literário. São Paulo: AnnaBlume, 1993.

PATTESON, Richard F.; SAURET, Thomas. The Consolation of Illusion: John Kennedy Toole's A Confederacy of Dunces. Texas Review, S.1., vol.4, n.1-2, p. 77-87, SpringSummer, 1983.

PRETI, Dino. Sociolingüística: os níveis de fala. São Paulo: EDUSP, 1977. . A gíria e outros temas. São Paulo: T.A.Queiroz Editores, 1984. . Estudos de Língua Oral e Escrita. Rio de Janeiro, Lucerna, 2004. 
. Tradução e aceitabilidade social das formas lingüísticas. In: ENCONTRO NACIONAL DE TRADUTORES - 4, 1990, São Paulo. Anais... São Paulo: Humanitas, 1990, p. 31-37.

PYM, Anthony. Translating Linguistic Variation: Parody and the Creation of Authenticity, 2000. Disponível em: www.tinet.org/ apym/on-line/authenticity.html. Acesso em: 3 abril 2006.

RICKFORD, Russel; RICKFORD, Russel John. Spoken Soul in Spirited Use: Writers. In: Spoken Soul. New York: John Wiley, 2000. Disponível em: <http:/ www.stanford.edu/ rickford/ L73/SS_Chap_6_Writers_for_L73.doc. Acesso em: 3 maio 2006.

RODRIGUES, Cristina Carneiro. Tradução e Diferença. São Paulo: Editora UNESP, 1999.

RUPPERSBURG, Hugh. The South and John Kennedy Toole's A Confederacy of Dunces. Studies in American Humor, S.1., v. 5 (2-3), p. 118-126, Summer-Fall, 1986.

SARIAN, Maristela Cury. A Tradução e a Sociolingüística: um estudo sobre The Color Purple e sua Tradução. 2002. 115 f. Dissertação (Mestre em Estudos Lingüísticos). Instituto de Biociências, Letras e Ciências Exatas da Universidade Estadual Paulista, São José do Rio Preto.

SIMPSON, Lewis P., New Orleans as a Literary Center: Some Problems. In: KENNEDY, Richard S. (Org.), Literary New Orleans. Baton Rouge e Londres: Louisiana State University Press, 1992.

TOOLE. J.K. A Confederacy of Dunces. New York: Grove Weidenfeld, 1987.

Livro, s.d.

A Confederacy of Dunces. Trad. Cristina Boselli. São Paulo: Círculo do

URBANO, Hudnilson. A Oralidade na Literatura (O Caso Rubem Fonseca). São Paulo: Cortez, 2000.

VENUTI, Lawrence. The Translator's Invisibility. In: Criticism, Detroit, Wayne State University Press, vol. 26, p. 179-212, 1986

. Escândalos da Tradução: por uma ética da diferença. Trad. Laureano Pelegrin et al. Bauru: EDUSC, 2002. 


\section{BIBLIOGRAFIA CONSULTADA}

ALMEIDA, Mônica de Souza. Tradução Literária e Plurilingüismo. Anais do Encontro Nacional de Tradutores. P. 223-227. São Paulo: Humanitas, 1996.

CALDAS-COULTHARD, C. R. Interação recriada: a representação da fala no discurso narrativo e a tradução. In: COULTHARD, M.; CALDAS-COULTHARD, C. R. (Orgs.). Tradução: teoria e prática. Florianópolis: Ed. da UFSC, 1991. p. 79-88.

CANDIDO, Antonio. et.al. A personagem de ficção. 6ed. São Paulo: Perspectiva, 1981.

CÉSAR, Ana Cristina. Escritos da Inglaterra. In: . Crítica e Tradução. São

Paulo: Ática, 1999.

DI VITO, M. Proposta de tradução de Huckleberry Finn. 1997. 141 f. Dissertação (Mestrado em Língua e Literatura Inglesa e Norte-Americana) - Faculdade de Filosofia, Letras e Ciências Humanas, Universidade de São Paulo, São Paulo.

GARCEZ, Pedro M. Diversidade Lingüística: Considerações para a Tradução. Trabalhos de Lingüística Aplicada, Campinas (33): 59-70, Jan./Jun., 1999.

PRETI. Dino. Para um aproveitamento sociolingüístico do texto literário. Tradução e comunicação, São Paulo, n. 3, p. 7-22, 1983.

. Oralidade e narração literária. Revista da ANPOLL, n.14, p.81-96, 1998.

. (Org). A língua falada e o diálogo literário. In: . Análise de textos orais. São Paulo: Humanitas, p. 215-28, 1993

TARALlO, F. Aspectos sociolingüísticos da tradução. Tradução \& Comunicação, São Paulo, n. 4, p. 91-106, 1984.

WILLEKER, Ana Abelin. Dialogue in Fictional Narrative- A Source of Conflict. Dissertação. 1987. 80 f. Dissertação (Mestre em Letras - Inglês e Literatura Correspondente). Universidade Federal de Santa Catarina, Florianópolis. 